\title{
Potential Research and Development Opportunities for Light Water Reactor Spent Nuclear Fuel at INL
}

Philip L. Winston

The INL is a

U.S. Department of Energy

National Laboratory

operated by

Battelle Energy Alliance

August 2018

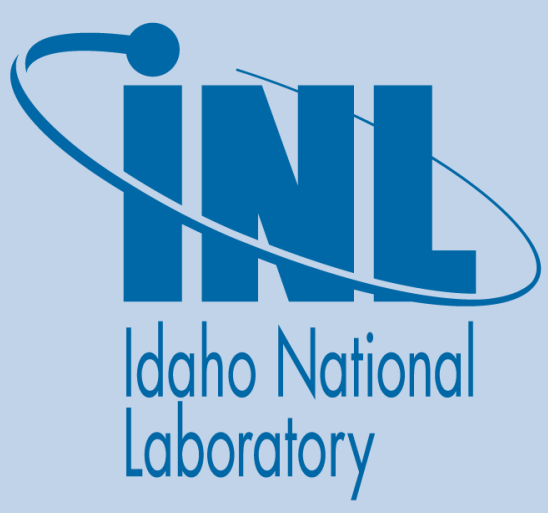




\section{DISCLAIMER}

This information was prepared as an account of work sponsored by an agency of the U.S. Government. Neither the U.S. Government nor any agency thereof, nor any of their employees, makes any warranty, expressed or implied, or assumes any legal liability or responsibility for the accuracy, completeness, or usefulness, of any information, apparatus, product, or process disclosed, or represents that its use would not infringe privately owned rights. References herein to any specific commercial product, process, or service by trade name, trade mark, manufacturer, or otherwise, does not necessarily constitute or imply its endorsement, recommendation, or favoring by the U.S. Government or any agency thereof. The views and opinions of authors expressed herein do not necessarily state or reflect those of the U.S. Government or any agency thereof. 
INL/EXT-18-45988

Revision 0

\title{
Potential Research and Development Opportunities for Light Water Reactor Spent Nuclear Fuel at INL
}

\author{
Philip L. Winston
}

August 2018

Idaho National Laboratory Idaho Falls, Idaho 83415

http://www.inl.gov

Prepared for the

U.S. Department of Energy

Office of Nuclear Energy

Under DOE Idaho Operations Office

Contract DE-AC07-05ID14517 



\section{Potential Research and Development Opportunities for Light Water Reactor Spent Nuclear Fuel at INL}

INL/EXT-18-45988

Revision 0

August 2018

Author:
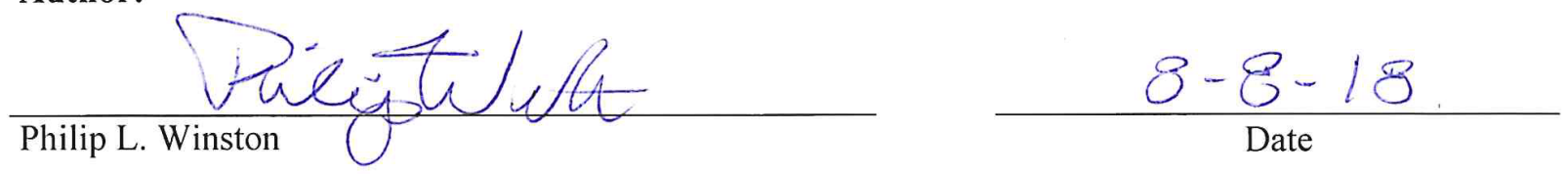

Approved by:
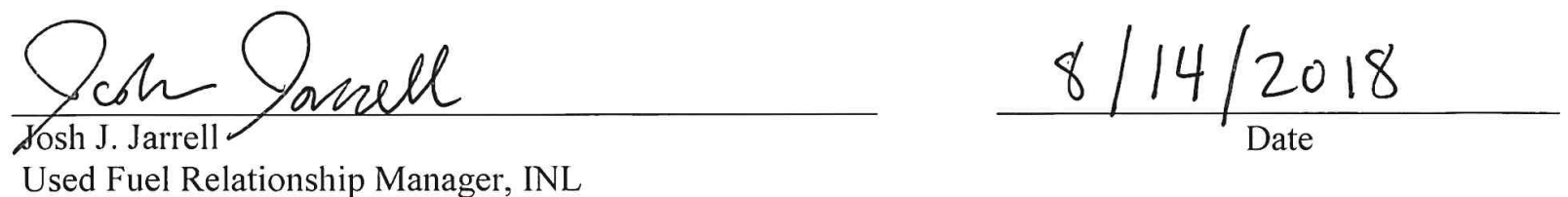



\section{REVISION LOG}

\begin{tabular}{|c|c|c|c|}
\hline Rev. & Date & Affected Pages & Revision Description \\
\hline 0 & $08 / 14 / 2018$ & All & New document. \\
\hline & & & \\
\hline & & & \\
\hline & & & \\
\hline & & & \\
\hline & & & \\
\hline & & & \\
\hline & & & \\
\hline & & & \\
\hline & & & \\
\hline & & & \\
\hline & & & \\
\hline & & & \\
\hline & & & \\
\hline & & & \\
\hline & & & \\
\hline & & & \\
\hline
\end{tabular}





\section{EXECUTIVE SUMMARY}

This report documents the commercial spent nuclear fuel currently in storage at Idaho National Laboratory with a specific focus on the potential research and development (R\&D) opportunities for this material. Commercial spent nuclear fuel is stored in dry casks on the INL site at the Idaho Nuclear Technology and Engineering Center (INTEC, formerly the Idaho Chemical Processing Plant or ICPP). This spent fuel was part of the DOE-industry cooperative dry cask demonstration project that began in 1983 and from historical fuel testing and treatment activities that had been performed at the Test Area North (TAN)-607 facility. Most of the fuel is "low burnup," but given that it was removed from the respective reactors between 1970 and 1985, it was representative for its time. The majority of the fuel is of the $15 \times 15$ Westinghouse PWR variety, though additional fuel types (e.g., TN-BRP) and configurations are also stored.

Potential R\&D opportunities identified are (1) the REA-2023 cask, (2) the TN-BRP cask, and (3) the Castor V/21 cask. Fuel from the TN-24P may be an alternative to the intact assemblies in the Castor V/21. Specifically, the REA-2023 cask contains 9 rods that have been exposed to air since 2005. These rods have a detailed pre-loading characterization and thus any changes in corrosion or geometry can most likely be attributed to the storage environment. In addition, similar rods to the nine in REA-2023 reside in the Castor V/21 cask whose environment has been maintained with inert nitrogen. The Castor V/21 cask also contains intact PWR assemblies that could be used to perform limited confirmation of the pyroprocessing approach. An alternative to the use of the Castor assemblies for pyroprocessing is the consolidated fuel that is stored in the TN-24P, which would not require removal from the assembly grid since it has already been packaged in accessible two-piece shell strongback containers. The TN-BRP cask contains a number of Gd-doped, low burnup assemblies that could be of use to validate code packages used to justify burnup-up credit for boiling water reactors (BWRs).

The INL dry casks are stored on the CPP-2707 pad at INTEC, adjacent to the CPP-603 Irradiated Fuel Storage Facility, which incorporates a dry hot cell that has the potential to receive a full scale commercial cask of the types identified. Several evaluations have been made regarding this task, including full scale mockup testing of the physical clearances required to remove and handle fuel assemblies and components. A proposed schedule of 14 months and cost of $\$ 5.3$ million was the outcome of analysis performed by Fluor Idaho and is included as Appendix A \& B.

In addition to the spent fuel at INL, there is also a full-scale mockup assembly that was fabricated for the Protypical Consolidation Demonstration Project to validate fuel rod consolidation approaches. The assembly was fabricated by Westinghouse as a 15 x 15 PWR, using Zircaloy-4 tubing and steel end fittings in accordance with product specifications. The only departure from specification is the use of copper metal in lieu of uranium oxide pellets to achieve a weight that is within $10 \%$ of the standard. 


\section{CONTENTS}

EXECUTIVE SUMMARY vii

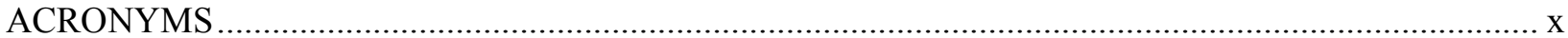

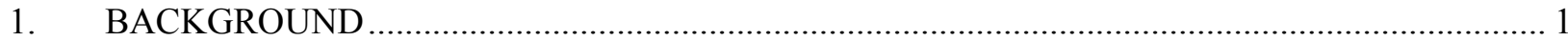

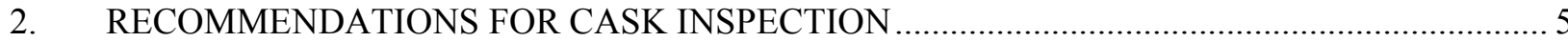

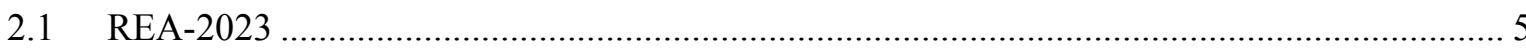

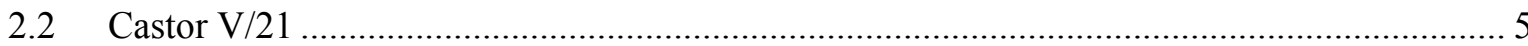

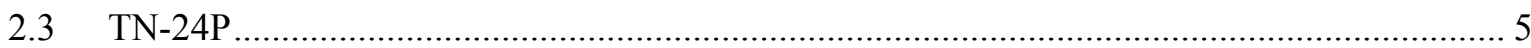

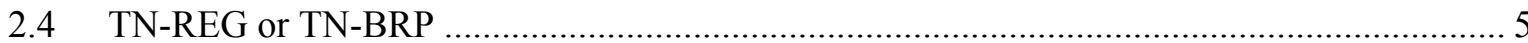

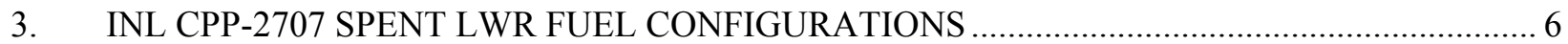

3.1 REA-2023 (Riddhalgh, Eggers and Associates) ............................................................. 6

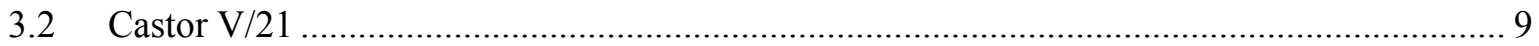

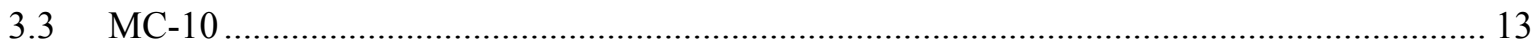

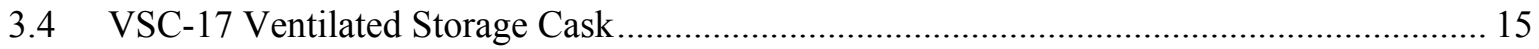

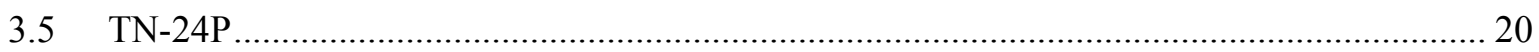

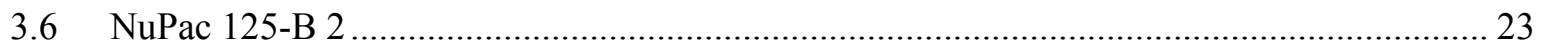

3.7 West Valley Casks: TN-BRP AND TN-REG ................................................................ 27

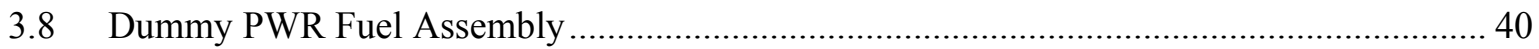

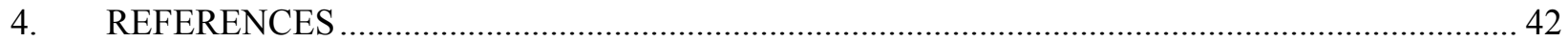

Appendix A Cost Estimate for Recovery of Cask and Opening in FHC (Fluor Idaho) ......................... A-1

Appendix B Cost Estimate Support Data Recapitulation .............................................................. B-1

\section{FIGURES}

Figure 1. Schematic drawing REA-2023 .................................................................................. 7

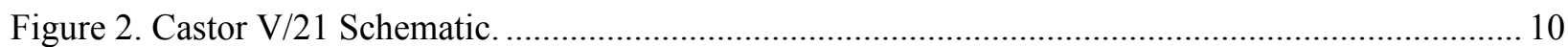

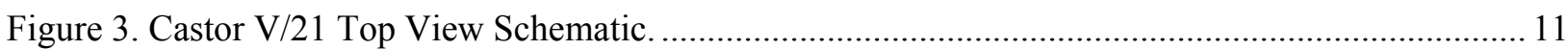

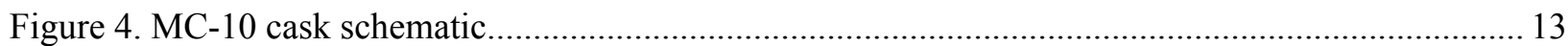

Figure 5. Dry Rod Consolidation Technology DRCT canister (EGG-WM-8059 p 132)....................... 16

Figure 6. Schematic representation of VSC-17 Cask............................................................................... 17

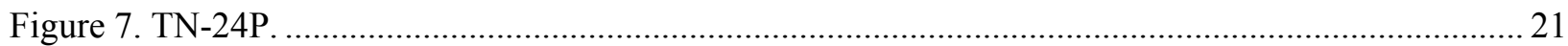

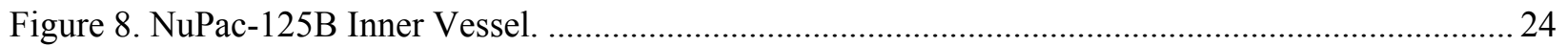

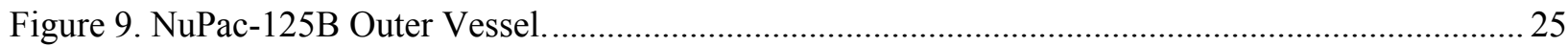

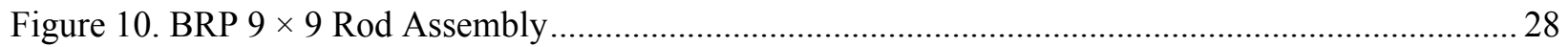




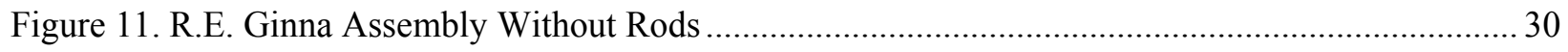

Figure 12. REG Assembly C30 Crack in Corner of Top Nozzle ............................................................ 32

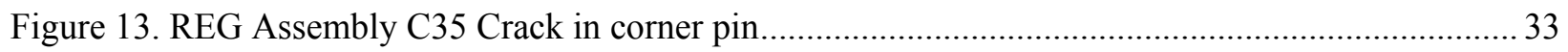

Figure 14. BRP Assembly CE50 Hole in cladding visible as orange deposit, crud is reddish................. 34

Figure 15. BRP Assembly CEP2 Broken rods with exposed plenum springs and damaged upper

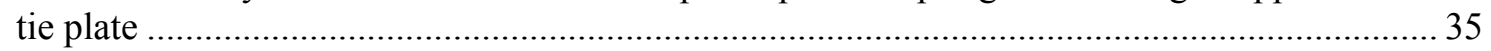

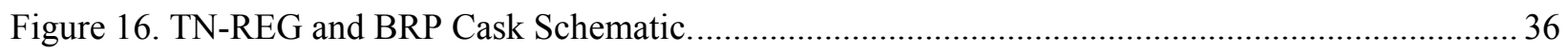

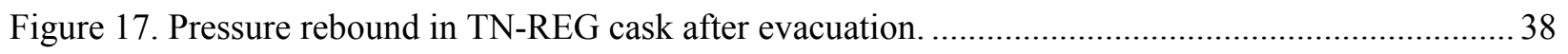

Figure 18. Annual hydrogen generation rates (mol\%/yr) as a function of the number of cask

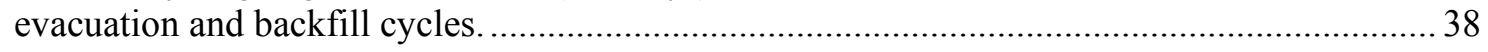

Figure 19. Pressure rebound in TN-BRP cask after evacuation............................................................. 39

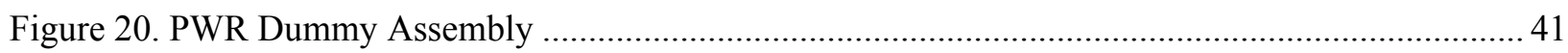

\section{TABLES}

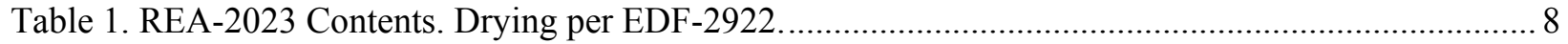

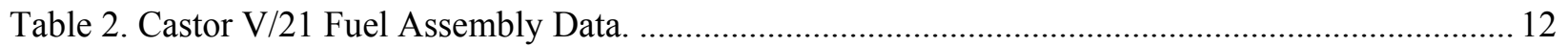

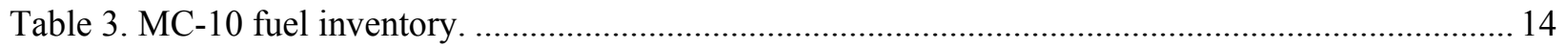

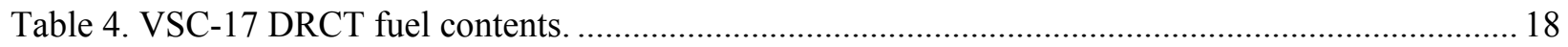

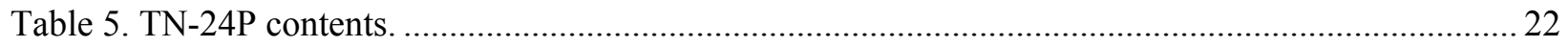

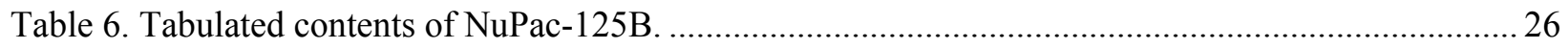

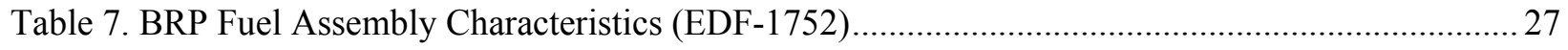

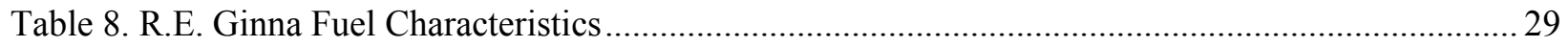

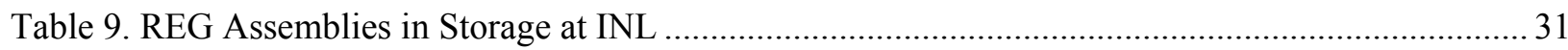

Table 10. Calculated Value for Liters of Retained Water for West Valley Stored Spent Nuclear

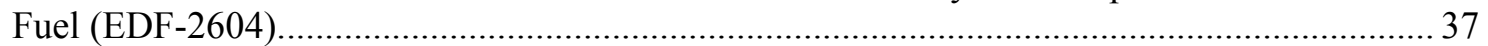

Table 11. Summary of the annual $\mathrm{H}_{2}$ generation rates in the TN-REG and TN-BRP cask cover

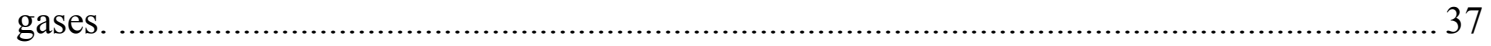

Table 12. TN-REG and BRP Headspace Gas Concentrations EDF-9069............................................. 39 


\section{ACRONYMS}

ART Advanced Reactor Technologies

BRP Big Rock Point reactor

BWR boiling water reactor

CPP Chemical Processing Plant

DOE Department of Energy

DRCT Dry Rod Consolidation Technology

EDF Engineering Design File

EPDM Ethylene Propylene Diene Monomer

EPRI Electric Power Research Institute

FHC Fuel Handling Cave

FP\&L Florida Power and Light

GNS Gesellschaft fur Nuklear-Service

ID Inner Diameter

IFSF Irradiated Fuel Storage Facility

INEEL Idaho National Engineering and Environmental Laboratory

INEL Idaho National Engineering Laboratory

INL Idaho National Laboratory

INTEC Idaho Nuclear Technology and Engineering Center

JFCS Joint Fuel Cycle Studies

LMITCO Lockheed Martin Idaho Technologies Company

MFC Materials and Fuels Complex (formerly Argonne National Laboratory-West)

MOX Mixed Oxide

MSB Multi-assembly Sealed Basket

NAC-LWT Nuclear Assurance Corporation-Legal Weight Truck (cask)

NuPac Nuclear Pacific

OD Outer Diameter

PWR pressurized water reactor

REA Riddhalgh, Eggers and Associates

REG R.E. Ginna

SAR Safety Analysis Report

SARP Safety Analysis Report for Packaging

TAN Test Area North

TMI Three-Mile Island 
TN Transnuclear

VEPCO Virginia Electric Power

WVDP West Valley Demonstration Project 


\section{Potential R\&D Opportunities for Light Water Reactor Spent Nuclear Fuel at INL}

\section{BACKGROUND}

Commercial Spent Nuclear Fuel at the Idaho National Laboratory (formerly the Idaho National Engineering Laboratory [INEL], and Idaho National Engineering and Environmental Laboratory [INEEL]) is present generally for three reasons: first as the remains of experimental work such as postirradiation examination or other experimentation, second as part of the 1983 DOE-industry cooperative Dry Cask Demonstration Project (McKinnon, 1997) that developed thermal data fundamental to the licensing of dry casks, and third as the un-processed feedstock from the West Valley Demonstration (reprocessing) Project. A small fraction of the light water reactor fuel in storage at Idaho National Laboratory (INL) has been irradiated to failure as a result of loss of coolant or extreme reactivity transient tests. This includes reconfigured mixed oxide (MOX) and high burnup fuel rods from Halden and BR-3 reactors in Europe. The following discussion addresses the materials that are stored in the dry fuel storage casks on the Idaho Nuclear Technology and Engineering Center (INTEC) Chemical Processing Plant (CPP)-2707 pad.

An example of the fuel brought to Idaho National Engineering Laboratory (INEL) for flow experimentation, the H.B. Robinson PWR fuel was partially disassembled and 90 of the 204 rods were used in axial gas flow experiments to validate laminar flow equations used in the FRAP-T2 and SSYST codes. (TREE-NUREG-1158, 1977.) Some of the 90 rods were sectioned for post-irradiation examination at the Materials Test Reactor (MTR) Hot Cells. Those sections were stored in the MTR canal and have since been transferred to dry storage in the INTEC CPP-603 Irradiated Fuel Storage Facility (IFSF). 113 rods are still in their original configuration as a partial assembly stored in the REA-2023 cask. The asfabricated data for the H.B. Robinson fuel rods was: Zirc-4 clad with outer diameter (OD) of $10.7 \mathrm{~mm}$, clad thickness of $0.62 \mathrm{~mm}$, overall length of $3.86 \mathrm{~m}, 3.1 \%$ enriched, sintered $\mathrm{UO}_{2}$ pellet with $0.93 \mathrm{~cm} \mathrm{OD}$ $\times 1.52 \mathrm{~cm}$ length at $92 \%$ theoretical density, with a fuel stack height of $3.65 \mathrm{~m}$, and plenum length of $17.35 \mathrm{~cm}$.

Although the cooperative agreements between DOE and the commercial power industry were largely administered by Pacific Northwest Laboratory (PNL), the facilities developed at INEL for testing of prototype nuclear aircraft reactors at Test Area North (TAN) provided hot cell space adequate for handling the full scale casks and the fuel necessary for the tests. The TAN-607 Hot Shop was a large scale dry hot cell that had $7 \mathrm{ft}$ thick shield walls, an overhead crane, electromechanical and manual manipulators that was connected to the TAN wet storage pool and small scale hot cells designed for PIE. The facility was demolished in 2007. https://www.youtube.com/watch? $\mathrm{v}=\mathrm{P}$ 4eQ41ttPQ The casks were stored on the TAN-791 pad approximately 18 miles north of their current location at INTEC from 1996 to 2003. They were moved to INTEC to put as much of INL's fuel storage at one facility as possible. Mikal McKinnon of PNL was responsible for performance testing of the casks at INEL TAN-607 Hot Shop from the project inception in 1983 to the end of testing in 1996.

The fuel brought to INL for the Dry Cask Demonstration Project was irradiated at Surry Power Station in Virginia or Turkey Point Nuclear Generating Station in Florida under an agreement between Virginia Electric Power (VEPCO) and Florida Power and Light (FP\&L) and the US Department of Energy (DOE). The assemblies from these two plants are (or were) standard $15 \times 15$ Westinghouse PWR fuel. Their typical burnup was $30 \mathrm{GWd} / \mathrm{MT}$ and their date of last irradiation ranged from 1976 to 1983. The fabrication specification indicates $21.41 \mathrm{~cm}$ square assemblies, $409.7 \mathrm{~cm}$ long with 204 rods of $386.1 \mathrm{~cm}$ length and rod OD of $10.72 \mathrm{~mm}$, made with Ziraloy-4 cladding, held in a series of 7 Inconel-718 spacer grids. The fuel pellets were $92 \%$ theoretical density $\mathrm{UO}_{2}$. The rod plenum was 17.27 $\mathrm{cm}$, partially filled by a stainless steel plenum spring. Clad thickness is $0.62 \mathrm{~mm}$. Prior to shipment the Surry and Turkey Point assemblies were visually, radiologically and ultrasonically measured to determine 
their rod integrity. Sip testing was performed as a radiological leak check, and the ultrasonic testing amounted to determination if the fuel rod pellet-clad gap was filled with water. At the time of receipt, the assemblies were determined to have at most $12 \mathrm{~mm}$ bend and twisting of approximately 10 degrees around the longitudinal axis.

Because fuel storage is expensive on a unit volume basis, a substantial amount of the PWR fuel was used in the Dry Rod Consolidation Technology (DRCT) project, which removed the fuel rods from their assembly structure and placed them in stainless steel consolidation canisters that have the same physical envelope as the original assembly. The consolidation is nominally 2:1 in that the 408 fuel rods in 2 assemblies are placed in the same volume as 204 rods from a single assembly occupied originally. Unlike some consolidations that were developed as in-pool at-reactor techniques this work was done in INEL's Test Area North (TAN) hot cells. This involved removal of the top and bottom nozzles and pulling the rods out of the intermediate spacer grids. This work is reported in great detail in EGG-WM8059. Other consolidation testing was done under the Prototypical Consolidation Demonstration Project, which resulted in fabrication of several unfueled full scale dummy assemblies, of which one remains in INL's inventory.

The Dry Cask Demonstration Project brought five different casks to Idaho for testing at the TAN Hot Shop. These are the Gesellschaft fur Nuklear-Service (GNS) Castor V/21 ductile iron cask, the REA-2023 lead shielded steel cask, the Westinghouse MC-10 steel cask, the Sierra Nuclear Pacific Ventilated Storage Cask VSC-17 concrete shielded, ventilated cask with carbon steel Multi-element Sealed Basket, and the forged steel TransNuclear TN-24P. The testing performed on these casks included heat transfer demonstrations using fully loaded casks filled with helium, nitrogen and air to validate design assumptions about the maximum fuel temperature achieved. Additional instrumentation was added to some designs to assure that local temperature extremes could be adequately measured. The VSC-17 had additional thermocouples of which some are still in service to monitor storage conditions. These five casks, along with the 2 West Valley casks and one TN-125B casks are stored on the CPP-2707 cask storage pad, which is an outdoor facility.

INL has three TN-125B casks that were designed to transport the Three-Mile Island (TMI)-2 core debris from Pennsylvania to Idaho. One (TN-125B-2) of these casks is in service on the CPP-2707 pad, containing debris from the Semiscale and Loss of Fluid Tests performed at TAN. (CONF-790803-13) as well as metallurgical mount samples from the TMI-2 core recovery and analysis efforts. The remaining 2 TN-125B casks are staged inside the INTEC CPP-666 Truck Bay and are filled with small-quantity research reactor fuels that have been classed as "cats and dogs." These fuels had accumulated in the fuel storage pools over the 50-year life of the Idaho Chemical Processing Plant (ICPP, renamed INTEC in 1997) due to their process-resistant chemistry or small quantity. CPP-666 is the operating wet fuel storage facility at INTEC operational since 1984, with six $30 \mathrm{ft}$ deep fuel storage pools. It was designed for wet storage and chemical dissolution of Navy fuels and is scheduled to end wet storage operations in 2023 due to decisions to stop reprocessing and to move Naval propulsion fuel to dry storage at the Expended Core Facility.

Small amounts of fuel from a multitude of different reactors including Shippingport Atomic Power Station (PWR), Connecticut Yankee Nuclear Power Plant (PWR), Dresden (BWR), Oyster Creek (BWR), Monticello Nuclear Generating Plant (BWR), Zion Nuclear Power Station (PWR), Brunswick Nuclear Generating Station (BWR), Quad Cities Nuclear Generating Station (BWR), Calvert Cliffs Nuclear Power Plant (PWR), Oconee Nuclear Station (PWR), and Maine Yankee Nuclear Power Plant (PWR) are present in the dry cask storage as well. Because a majority of the small quantity fuel rods in the dry casks came from the Test Area North (TAN)-607 storage pools, the primary reference is Dick McCardell's opus, The Characteristics of Commercial Nuclear Materials Stored in TAN Pool, INEL-INT-98-00767, Lockheed Martin Idaho Technologies Company, September 1998. 
The West Valley Demonstration Project (WVDP) was a reprocessing facility for commercial light water reactor fuels, which operated from 1966, through November 1971. It has since been decontaminated and decommissioned by the U.S. Department of Energy (DOE), which assumed control of the site in 1982. In the current storage configuration at INTEC CPP-2707, cask pressures range from 0.7 to 1.0 atmospheres. As noted in the discussion of the TN-24/40/68 cask designs, the identified pressure limit is 4 atmospheres absolute.

In July 2003, 125 commercial spent nuclear fuel assemblies were shipped by the DOE from West Valley Demonstration Project (WVDP) to the Idaho National Engineering and Environmental Laboratory (INEEL) for interim dry storage. The spent fuel consists of $40(14 \times 14 \mathrm{rod})$ assemblies of pressurized water reactor (PWR) fuel from the Robert E. Ginna reactor (REG) and 85 assemblies of an early design of boiling water reactor (BWR) fuel (ranging from $7 \times 7$ to $11 \times 11$ rod type) from the Big Rock Point Reactor (BRP). Visual examination indicated that at least 7 of the assemblies (3 PWR and 4 BWR) have damaged cladding and corrosion of the exposed fuel meat.

There are other commercial fuel rods present at INL as sectioned parts that are stored in the dry canister system at the Irradiated Fuel Storage Facility which is part of INTEC's CPP-603. The remains of some of the irradiated H.B. Robinson, Halden, Dresden and Saxton fuels are located in four canisters. Other canisters contain assemblies specifically put together using irradiated high burnup rods for experimentation for high temperature transient testing in the Power Burst Facility.

The casks are bolted lid designs that incorporate vent and purge lines that are used for sampling the headspace gas to determine whether a flammable concentration of hydrogen may have accumulated. DOE safety requirements prohibit the vessel hydrogen concentration exceeding $4 \mathrm{vol} \%$. For casks in which drying has been incomplete, or some cask component contains material that may be liberated and radiolyzed, the safety basis (SAR-112) requires that periodic sampling be performed per the monitoring plan (PLN-1720). The REA-2023 is sampled annually, the VSC-17 every 3 years and the TRN-REG and BRP are to be sampled every 5 years. The remainder are sampled every 10 years. All of the casks have real time online pressure and temperature monitoring.

Because the REA-2023 cask contains 9 rods from the Castor V/21 T11 assembly that were not destructively evaluated in 1999-2001, they may be a valuable comparison reference. The possibility of opening the 2023 cask in the CPP-603 Irradiated Fuel Storage Facility (IFSF) Fuel Handling Cave was evaluated in TEV-1187, "Feasibility of Using the Irradiated Fuel Storage Facility to Remove Commercial Used Fuel from the REA-2023 Cask" (Wahnschaffe, 2011) with the conclusion that retrieval should be possible via this pathway if the 50 ton east-west truckbay crane were upgraded or a temporary portable gantry crane was used.

This topic was revisited in report FCRD-UFD-2013-000027, Viability of Existing INL Facilities for Dry Storage Cask Handling, which again concluded that with truck bay crane capacity upgrade, cask handling in the IFSF cave would be feasible.

Continuing in this vein, CH2M-WG Idaho (CWI) CWI RPT-1350, Analysis of CPP-603 for Opening Large Dry-Storage, Used Nuclear Fuel Casks, Task 3 Report, by Tolman, et. al. describes the confirmation that a TN-32/40 mockup cask can be installed in the IFSF Transfer Car without modifications to the car itself. It also confirmed that a mockup fuel assembly could be removed from the mockup cask and effectively manipulated inside the Fuel Handling Cave.

Given the functional confirmation and the 2017 upgrade of the 50-ton CRN-SF-101 crane to a two unit 75-ton crane, the current Idaho Cleanup Project contractor, Fluor Idaho was requested to prepare a cost estimate for retrieval and opening of the Castor V/21 cask. This cost estimate is included as Appendices A and B.

The scope of the retrieval and opening includes: Revising the safety basis documents for the IFSF to handle the commercial fuel, developing procedures for performing the individual tasks, and walking 
down all activities that are not currently performed in the facility, meaning a contractor Management SelfAssessment and probably a DOE Readiness Assessment.

Individual tasks are 1) Bringing the V/21 cask from the CPP-2707 pad to CPP-603. This will involve rental of a gantry crane and heavy haul transport and upgrading the perimeter road from 2707 to 603 to accommodate the heavy haul transport. 2) Placing the V/21 cask in the cask transfer car. This will require fabrication of a transfer car insert to support the cask. 3) Moving the V/21 cask into the Fuel Handling Cave (FHC) 4) Opening the cask lid and setting it aside. This may require a stand to assure that the cask sealing surfaces are not damaged when set down. 5) Removal of a fuel assembly and setting it in lag storage in a cave well. This will require purchase or fabrication of a lifting tool and possibly a basket that will assure orientation in the cave well. 6) Replacing the lid on the V/21 cask. 7) Removal of the cask from the CPP-603 facility and return to the storage pad. 8) Movement of the NAC-LWT (NAC International Legal Weight Truck) cask into the FHC. Since the NAC-LWT is frequently used in this facility for TRIGA research reactor fuel transfers, little safety document or procedure revision will be required. 9) Placement of the fuel assembly in the NAC-LWT cask using an approved PWR canister. 10) Transportation of the assembly from INTEC to the Materials and Fuels Complex (MFC) Hot Fuels Examination Facility (HFEF). Movement of the cask will require development of a transport plan unless it is concluded that this can be made as an in-commerce shipment. The NAC-LWT SARP payload options include transport of a PWR assembly.

Assuming that the estimate and the proposed project is based on recovery of fuel to support Joint Fuel Cycle Studies work in pyroprocessing, once the fuel assembly reaches HFEF, equipment for removing the assembly end fixtures and removing and handling rods will be required to have been developed. As an alternative to dismantling an intact assembly from the Castor V/21, removal of a DRCT package from the $\mathrm{TN}-24 \mathrm{P}$ cask may provide a larger payload without going through the development of derodding equipment. The DRCT package is a two piece shell that has the same dimensions as a PWR assembly, but contains the rods from two assemblies. Since the rods have already been removed from their respective assemblies, it would be a matter of attaching lifting adapters to the rod ends and transferring them into the JFCS headend to remove the pellets.

Pyroprocessing, sometimes referred to as electrorefining, involves dissolving metal fuel in a molten salt electrolyte and applying a current to separate uranium and plutonium. The process was developed by Argonne National Laboratory as a means of processing sodium cooled EBR-II reactor metal fuel so that it could be remanufactured in the Fuel Conditioning Facility Hot Cell. The Joint Fuel Cycle Studies activities involve processing commercial light water reactor fuel by first converting the oxide to metal, then electrorefining to produce a MOX metal fuel for a sodium cooled reactor. This work is being done at a pilot scale as a collaboration with team memebers researchers as a demonstration of a closed-cycle process for converting spent LWR fuel into fast reactor fuel. Due to an embargo on commercial fuel shipments to Idaho, the originally designated feedstock is not available. Given that the original fuel is not available, it has been suggested that some of the commercial fuel stored in the dry casks could provide the necessary feedstock for the process. 


\section{RECOMMENDATIONS FOR CASK INSPECTION \\ 2.1 REA-2023}

The REA-2023 contains the 9 rods that were removed from the T-11 assembly that is stored in the Castor V/21 cask that was inspected in 1999. By the time that this cask could be opened, these rods will have been out of their assembly for 20 years. Due to challenges during the drying process at TAN, it has been assumed that the cask atmosphere is not completely free of water vapor. For at least the last 10 years, the cask storage atmosphere has been $80 \%$ nitrogen and $20 \%$ oxygen (air). There are several points at which air may have entered the cask, although the most likely location is at a fitting at the pressure transducer. Being able to examine the 9 Surry T-11 rods previously stored in the Castor V/21 after this duration under these conditions will provide a basis for projecting the long term performance of fuels of this burnup and vintage, specifically if the rods are exposed to non-inert atmosphere. These 9 rods may be usable as feedstock for the Joint Fuel Cycle Studies pyroprocessing activities at MFC.

The other contents of this cask include comparable burnup PWRs that have been used for other baseline post-irradiation examination, such as the Connecticut Yankee Nuclear Power Plant and HB Robinson PWR assemblies, and the Peach Bottom BWR assemblies that were provided for evaluation of pellet-clad interaction concerns.

The loose rod fuel storage basket includes some Quad City BWR rods or segments that may include gadolinium that may be useful for evaluation of burnup credit for BWRs with integral poisons.

\subsection{Castor $\mathrm{V} / 21$}

Because the Castor V/21 was inspected in 1999, repeating this process when facility schedules allow is important in that evaluation of the fuel and components as stored in helium backfill would provide a comparison to the 9 rods that have spent the interim in nitrogen and air.

\subsection{TN-24P}

If the impasse between the State of Idaho regarding importing commercial spent fuel cannot be resolved, it has been suggested that fuel from the Castor V/21 could be used for the Joint Fuel Cycle Studies pyroprocessing development at Materials and Fuels Complex (MFC). Because the fuel in the Castor V/21 is largely intact assemblies, part of the process for harvesting fuel will require development of new dry rod removal techniques and equipment. To avoid this development task the DRCT fuel in the TN-24P is contained in two-piece strongback shells that would make twice as many rods available per unit without derodding equipment.

\subsection{TN-REG or TN-BRP}

The West Valley casks may contain useful information regarding the effects of transportation of fuel across the country as well as the effects of multiple cycles of vacuum drying. It may be assumed that the reported crud layers would be displaced by fretting of the guide spacers within the assemblies. 


\section{INL CPP-2707 SPENT LWR FUEL CONFIGURATIONS 3.1 REA-2023 (Riddhalgh, Eggers and Associates)}

The REA-2023 cask was built with the intent of storing 52 intact BWR type fuel assemblies, each generating up to $0.4 \mathrm{~kW}$. It is constructed of stainless steel and is 192.62 tall and 87.56 inches outside diameter. It has 4.25 inches of lead combined with 3 inches of stainless steel for gamma ray shielding. Its empty weight is 96 tons. It has a 61 -inch inner diameter (ID) cavity that is 177.25 inches tall. The OD of the 3" stainless steel structural component is 75.06 inches, with the balance of the total OD being 6 inches of neutron shield material.

The original design included a copper-stainless steel-boral-poisoned fuel basket that is not used at INTEC. The current insert is constructed of stainless steel and depends on physical spacing to assure subcriticality. The cask assembly is designed to withstand a 5-foot drop in any orientation.

The primary lid is secured with 1.25 inch diameter bolts and is sealed to the cask body with two elastomer O-rings. The cask has two drain penetrations and one vent penetration that is used for gas sampling. There are also four instrumentation penetrations near the top of the cask.

The stored contents include one Connecticut Yankee PWR assembly, one partial HB Robinson PWR assembly, two Peach Bottom BWR assemblies, and two Dresden BWR assemblies. The six PWR and BWR assemblies are stored in 0.25 inch walled stainless steel overpacks (aka coffins) that incorporate a strongback to minimize flexure of the assemblies during horizontal handling.

Some of the remains of the Loss-of-Fluid-Test core that was melted as a final experiment are stored in the REA-2023. The LOFT FP-1 assembly is contained in a 198 inch long cylindrical can. LOFT FP-2 debris is contained in 12 stainless steel containers 10.5 inches square $\times 12.57$ inches tall. The epoxied FP--2 metallurgical mounts are stored in 3 stainless steel containers 10.5 inches square by 13.7 inches tall.

The other components stored in the REA-2023 include the Loose Rod Fuel Basket, which contains parts and pieces of rods from 14 different commercial reactors.

The $10 \times 10$ basket contains 35 rods individually encapsulated, including 21 from the Peach Bottom BWR, 12 from the H.B. Robinson PWR, and 2 from the FP-1 experiment.

The Surry basket contains 9 of the 12 rods that were removed from the Surry T-11 assembly from the Castor V/21 during the 1999 inspection. This inspection is documented in report INEEL/EXT-01-00183 Dry Cask Characterization Project Phase I. Bare and Torgersen, August 2001. EPRI's report on the topic is Dry Cask Inspection after 15 years, Electric Power Research Institute (EPRI) 1002882.

Unlike the Heated Vacuum Drying System used to dry the Three-Mile Island core debris canisters, the REA-2023 was dried using only vacuum and decay heat, and excluded the 9-pin Surry basket to assure that the temperature in the cask did not exceed $100^{\circ} \mathrm{C}$ so as to remain within the air permit parameters for the process at that time. (EDF-2922) The result was the presence of visible water, which was manually removed prior to final closure. This separate removal step was assumed to leave liquid water in occluded spaces, yielding a humid cask headspace. (EDF-2560) 


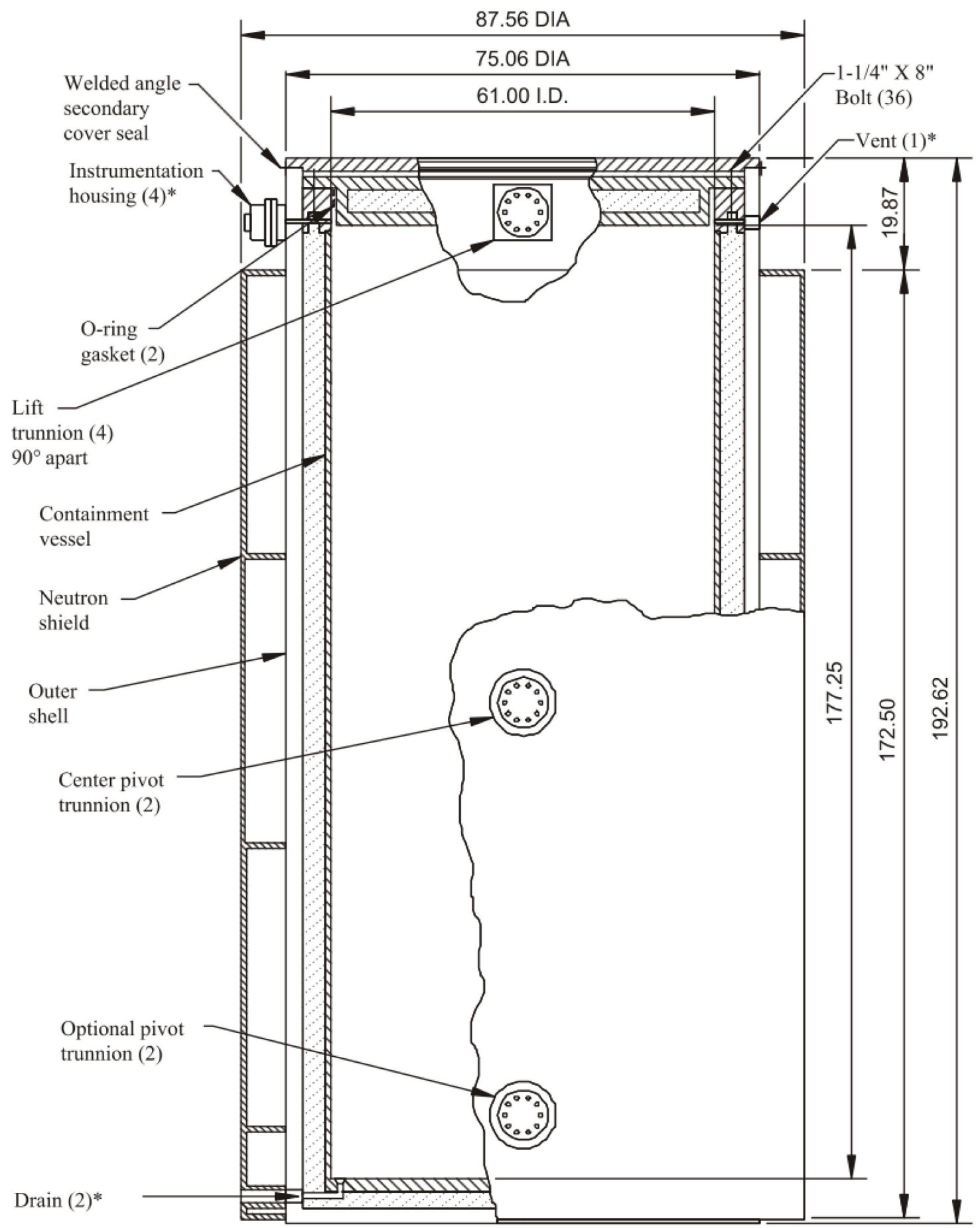

Dimensions are shown in inches

* Rotated from true position

Figure 1. Schematic drawing REA-2023.

The contents of the REA are described in tabular fashion in Table 1 below. 
Table 1. REA-2023 Contents. Drying per EDF-2922.

\begin{tabular}{|c|c|c|c|c|c|c|c|}
\hline Reactor Name/type & $\begin{array}{l}\text { Assembly } \\
\text { Number }\end{array}$ & Array/Number of Rods & Burnup & Enrichment & Storage & Interest & Clad Matl \\
\hline $\begin{array}{l}\text { Connecticut } \\
\text { Yankee. } \\
\text { (Haddam } \\
\text { Neck)/PWR }\end{array}$ & S004 & $\begin{array}{l}15 \times 15 / \\
204 \text { originally, } \\
200 \text { stored, } \\
4 \text { rods taken out at } \\
\text { BMI-Columbus } \\
\text { replaced with SS }\end{array}$ & $32.151 \mathrm{GWd} / \mathrm{MTU}$ & $\begin{array}{c}4 \% \\
3,3.24,3.67\end{array}$ & $\begin{array}{l}\text { Control Rod Cluster control } \\
\text { assembly with spider \& CR } \\
\text { removed } \\
\text { In PWR strongback in Coffin K }\end{array}$ & $\begin{array}{l}20 \text { guide tubes cut } \\
\text { above bottom nozzle } \\
8 \text { SS rods (orig. } 22.83 ” \\
\text { shorter than std } 15 \times 15 \\
\text { W PWR }\end{array}$ & $304 \mathrm{SS}$ \\
\hline $\begin{array}{l}\text { Peach Bottom } \\
\text { 2/BWR }\end{array}$ & $\begin{array}{l}\text { PH0006 } \\
\text { PH0462 }\end{array}$ & $\begin{array}{l}7 \times 7 \\
40 \text { rods } \\
33 \text { rods }\end{array}$ & 8-12 GWd/MTU & $1.13,1.91,2.95$ & - & $\begin{array}{l}\text { Presumed PCI failure } \\
1976\end{array}$ & ZR-2 \\
\hline H. B. Robinson/PWR & B05 & $\begin{array}{l}15 \times 15 / 204 \text { originally } \\
113 \text { rods left }\end{array}$ & - & 3.1 & $\begin{array}{l}\text { PWR StrongbackCoffin C } \\
\text { Upper endbox rmvd OL 159.7”: }\end{array}$ & $\begin{array}{l}\text { Strongback Dwg } \\
\text { BCD \#79986 } \\
\# 423212\end{array}$ & Zr-4 \\
\hline Dresden/BWR & $\begin{array}{l}\text { E00161 } \\
\text { UN } 0064\end{array}$ & \begin{tabular}{|l|}
$6 \times 6$ \\
36 rods, intact \\
19 rods \\
117 ' long \\
\end{tabular} & - & Strongbk $9.57 \mathrm{sq}$ & $\begin{array}{l}\text { BWR Strongback } \\
\text { Coffin D } \\
\text { Coffin H }\end{array}$ & $\begin{array}{l}\text { 9'9" made of } \\
4-28 \text { segments }\end{array}$ & $\mathrm{Zr}-2$ \\
\hline 10x10 Storage Rack & \begin{tabular}{|l|} 
FP-1 (2) \\
HBR (12) \\
PB (21)
\end{tabular} & $\begin{array}{l}35 \mathrm{Al} \text { encapsulation } \\
\text { tubes }\end{array}$ & - & - & \begin{tabular}{|l|}
$12 \mathrm{HBR}(\mathrm{B} 05)$ \\
$21 \mathrm{~PB}$ \\
$(7 \mathrm{PH} 0006,14 \mathrm{PH} 0462)$
\end{tabular} & - & - \\
\hline Surry Basket & T11 & 9 rods & - & - & $\begin{array}{l}\text { From } 1999 \text { Castor V/21 } \\
\text { inspection }\end{array}$ & $\begin{array}{l}9 \text { of the } 12 \text { rods pulled } \\
\text { from T11 in } 1999\end{array}$ & - \\
\hline $\begin{array}{l}\text { Loose Fuel Rod } \\
\text { Storage Basket } \\
\text { See RKMcC } \\
\text { Table 8-3 p157 } \\
\text { QdCty Appx B67 }\end{array}$ & \begin{tabular}{|l} 
Turkey Point \\
Shippingport \\
Conn.Yankee \\
Oyster Creek \\
Monticello \\
Surry \\
Zion \\
Brunswick \\
Quad City \\
Calvert Cliffs \\
HBR \\
Oconee \\
ME Yankee \\
REG \\
\end{tabular} & $\begin{array}{l}\text { 108 SS tubes } 0.5 "- \\
0.75 " \text { OD. } 106 \text { filled, }\end{array}$ & - & $\begin{array}{l}\text { Strongback } \\
154-159^{\prime} \\
\text { Ovrpk } \\
175 \times 14.9 \mathrm{sq}\end{array}$ & $\begin{array}{l}\text { Same dimensions as } 15 \times 15 \\
\text { PWR assembly } 8.5 \times 8.5 \times 161 \\
\text { Coffin J overpack }\end{array}$ & $\begin{array}{l}\text { Rods from } 14 \text { reactors } \\
\text { Quad City Gd2O3? } \\
4 \text { tube position UO2 } \\
\text { ref 2,p131;15,p136 }\end{array}$ & - \\
\hline
\end{tabular}




\subsection{Castor $\mathrm{V} / 21$}

The GNS Castor V/21 was designed to contain 21 intact PWR assemblies. The cask body is constructed of a single casting of ductile iron. The cask is approximately $7.87 \mathrm{ft}$ outside diameter and $16 \mathrm{ft}$ high. It weighs approximately 112 tons fully loaded. The cask body wall is approximately $14.9 \mathrm{in}$. thick iron with lengthwise holes into which two concentric rows of polyethylene neutron shielding has been inserted. The cask cavity is 60 inches inside diameter and 163 inches long. The cask body incorporates 73 circumferential external cooling fins as part of the casting. It is painted with green epoxy paint. The top of the cask is closed with 12 " thick primary and 3.5 inch thick secondary stainless steel lids bolted into the cask and sealed with metallic and elastomeric O-rings. In typical operation, the pressure between the primary and secondary lids is monitored as an indication of loss of seal function. At CPP-2707, only the primary lid is in use.

The fuel basket is constructed of borated $(1 \mathrm{wt} \%)$ stainless steel plates that form 8.7 inch square storage positions.

Vent and purge lines are incorporated into the cask for venting, vacuum drying and backfilling, also serving as headspace gas sampling ports. On the provided drawing, the vent line is indicated as the flushing pipe. At CPP-2707, temperature is measured with a skin thermocouple potted into the space between cooling fins.

The Castor V/21 design was originally developed for service at Surry Power Station, which has $25 \mathrm{~V} / 21$ and one X/33 (scaled up version to hold 33 PWR) units. A schematic of the Castor design is shown in Figure 2 below.

The Castor V/21 in service at CPP-2707 contains 21 standard Westinghouse PWR assemblies from the Surry Power Station located on Hog Island Road in Surry County, Virginia. The assemblies are all intact except for Assembly T-11, which had 12 rods removed for non-destructive and destructive examination in 1999, when the cask was last opened. Inspection of the fuel indicated no change between the visual inspection in 1985 and 1999, in that the fuel rods had a gray mottled appearance and retained their adherent zirconium oxide and crud which was difficult to remove during surface sampling. This inspection is documented in report INEEL/EXT-01-00183 Dry Cask Characterization Project Phase I. Bare and Torgersen, August 2001. EPRI's report on the topic is Dry Cask Inspection after 15 years, Electric Power Research Institute (EPRI) 1002882.

The main observed issue was that 15 of the 16 stitch welds on the basket were cracked. It was concluded after review of the 1985 report (EPRI-4887) that the cracks had occurred during initial thermal testing. This has not been borne out in subsequent headspace gas sampling of the cask over the ensuing 30 years. No detectable krypton or xenon isotopes have been identified since the casks have been moved to INTEC.

A tabular summary of the fuel assemblies in the Castor V/21 is shown as Table 2 . 


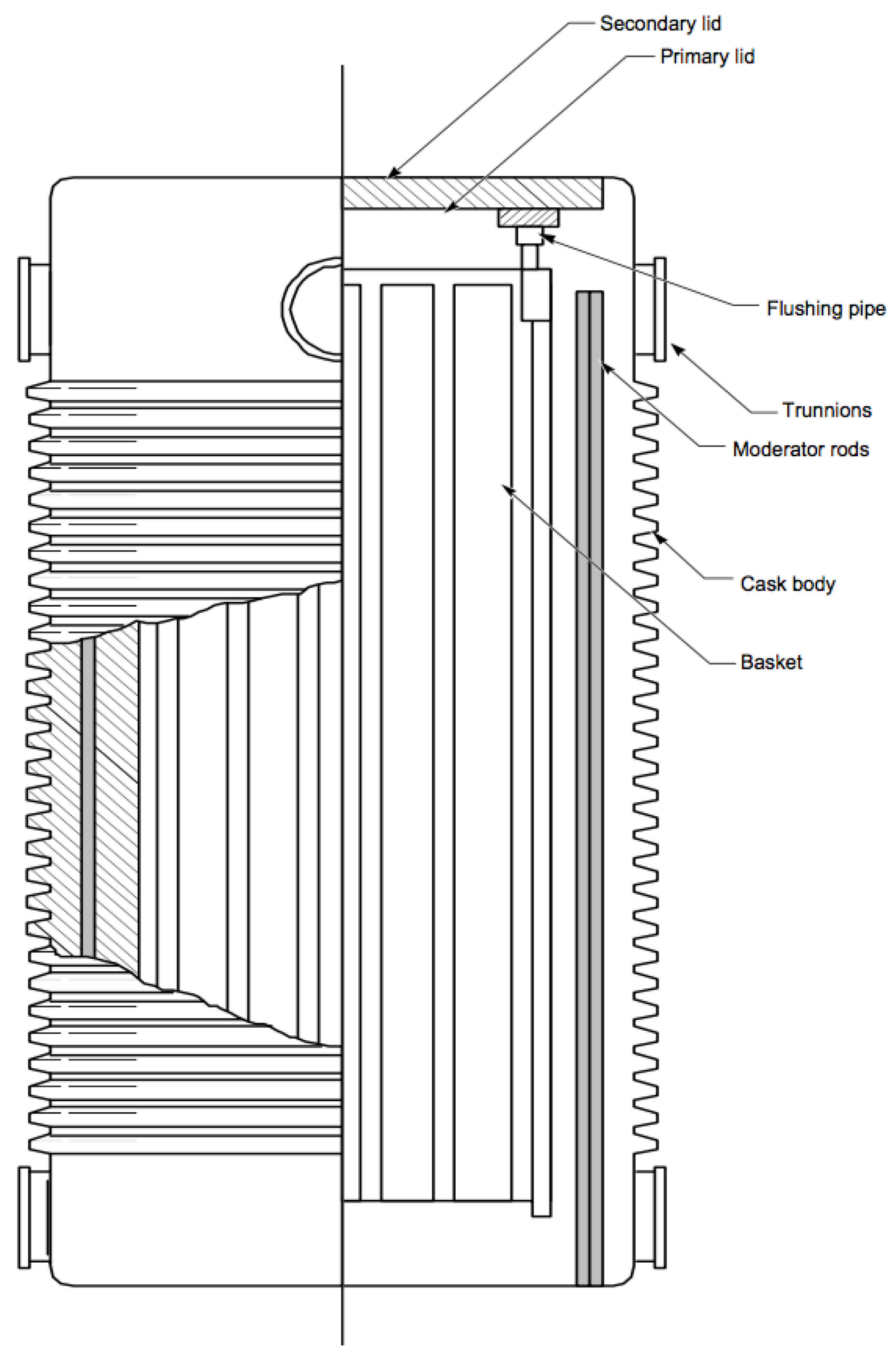

Figure 2. Castor V/21 Schematic. 


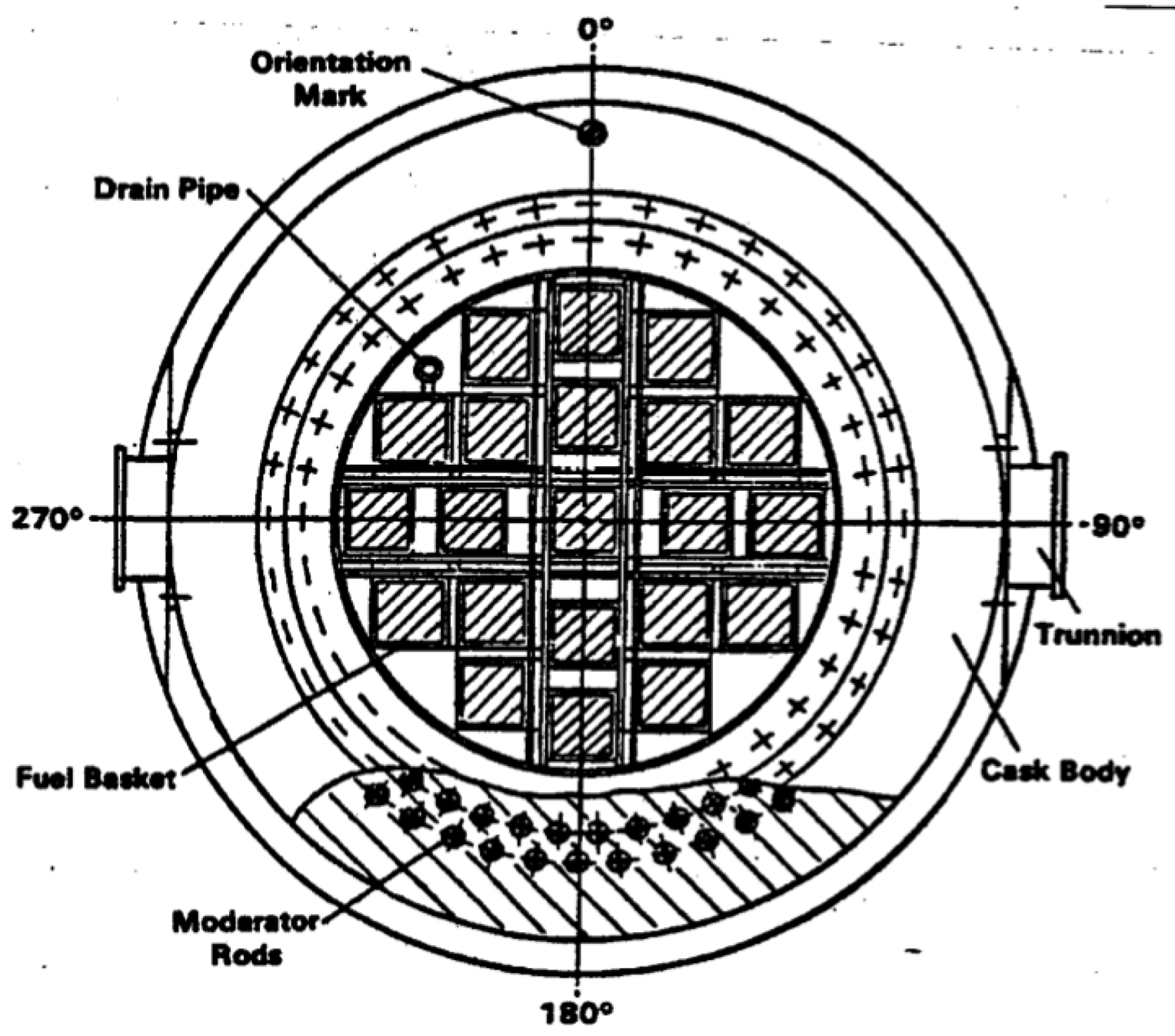

Figure 3. Castor V/21 Top View Schematic. 
Table 2. Castor V/21 Fuel Assembly Data.

\begin{tabular}{|c|c|c|c|c|c|c|c|}
\hline $\begin{array}{c}\text { Reactor } \\
\text { Name/type }\end{array}$ & $\begin{array}{c}\text { Assembly } \\
\text { Number }\end{array}$ & $\begin{array}{c}\text { Array/Number } \\
\text { of Rods }\end{array}$ & $\begin{array}{c}\text { Burnup } \\
\text { MWd/MT }\end{array}$ & Enrichment & Storage & Interest & Clad Matl \\
\hline \multicolumn{8}{|l|}{ Surry/PWR } \\
\hline & T03 & $15 \times 15 / 204$ & 35722 & & $11 / 06 / 81$ & Std W PWR & $\mathrm{Zr}-4$ \\
\hline & T07 & & 35722 & & $11 / 06 / 81$ & $\begin{array}{l}161 \text { L overall } \\
144 " \text { fueled }\end{array}$ & \\
\hline & T08 & & 35722 & & $11 / 06 / 81$ & & \\
\hline & T09 & & 35722 & & $11 / 06 / 81$ & & \\
\hline & $\mathrm{T} 11$ & & 35722 & & $11 / 06 / 81$ & $\begin{array}{l}12 \text { rods removed } 1999 \\
\text { inspection }\end{array}$ & \\
\hline & $\mathrm{T} 12$ & & 35722 & & $11 / 06 / 81$ & & \\
\hline & $\mathrm{T} 13$ & & 35722 & & $11 / 06 / 81$ & & \\
\hline & T16 & & 35722 & & $11 / 06 / 81$ & & \\
\hline & V01 & & 30214 & & $06 / 30 / 83$ & & \\
\hline & V04 & & 31146 & & $11 / 06 / 81$ & & \\
\hline & V05 & & 31511 & & $11 / 06 / 81$ & & \\
\hline & V08 & & 31146 & & $06 / 30 / 83$ & & \\
\hline & V09 & & 30214 & & $06 / 30 / 83$ & Clad Crack? & \\
\hline & V11 & & 29823 & & $06 / 30 / 83$ & & \\
\hline & $\mathrm{V} 12$ & & 31146 & & $06 / 30 / 83$ & & \\
\hline & V13 & & 29823 & & $06 / 30 / 83$ & & \\
\hline & V14 & & 29823 & & $06 / 30 / 83$ & Clad Crack? & \\
\hline & V15 & & 29823 & & $06 / 30 / 83$ & & \\
\hline & V24 & & 31146 & & $11 / 06 / 81$ & & \\
\hline & $\mathrm{V} 25$ & & 30214 & & $06 / 30 / 83$ & & \\
\hline & V27 & & 30214 & & $06 / 30 / 83$ & & \\
\hline
\end{tabular}




\section{$3.3 \quad$ MC-10}

The Westinghouse MC-10 cask is a forged low-alloy steel cask with 10-inch thick walls and 11-inch thick bottom. The top shield is approximately 9 inches thick and is sealed with a metallic O-ring. Its cavity is 188 inches long and 88 inches diameter. The outer wall of the steel cask body is surrounded by a layer of BISCO NS-3 neutron absorber. Heat transfer is improved by the use of 24 fins that are arranged along the axis of the cask. The general arrangement is as shown schematically in Figure 3. The design uses a 24 position aluminum basket structure, of which only 18 positions are filled at CPP-2707. The fuel stored in this cask is intact PWR, 12 assemblies from Surry, 6 from Turkey Point, with no debris or DRCT cans. A tabular listing of the fuel is shown in Table 3. The cask was originally designed for deployment at Surry, which has one example in service. No other sites adopted this design.

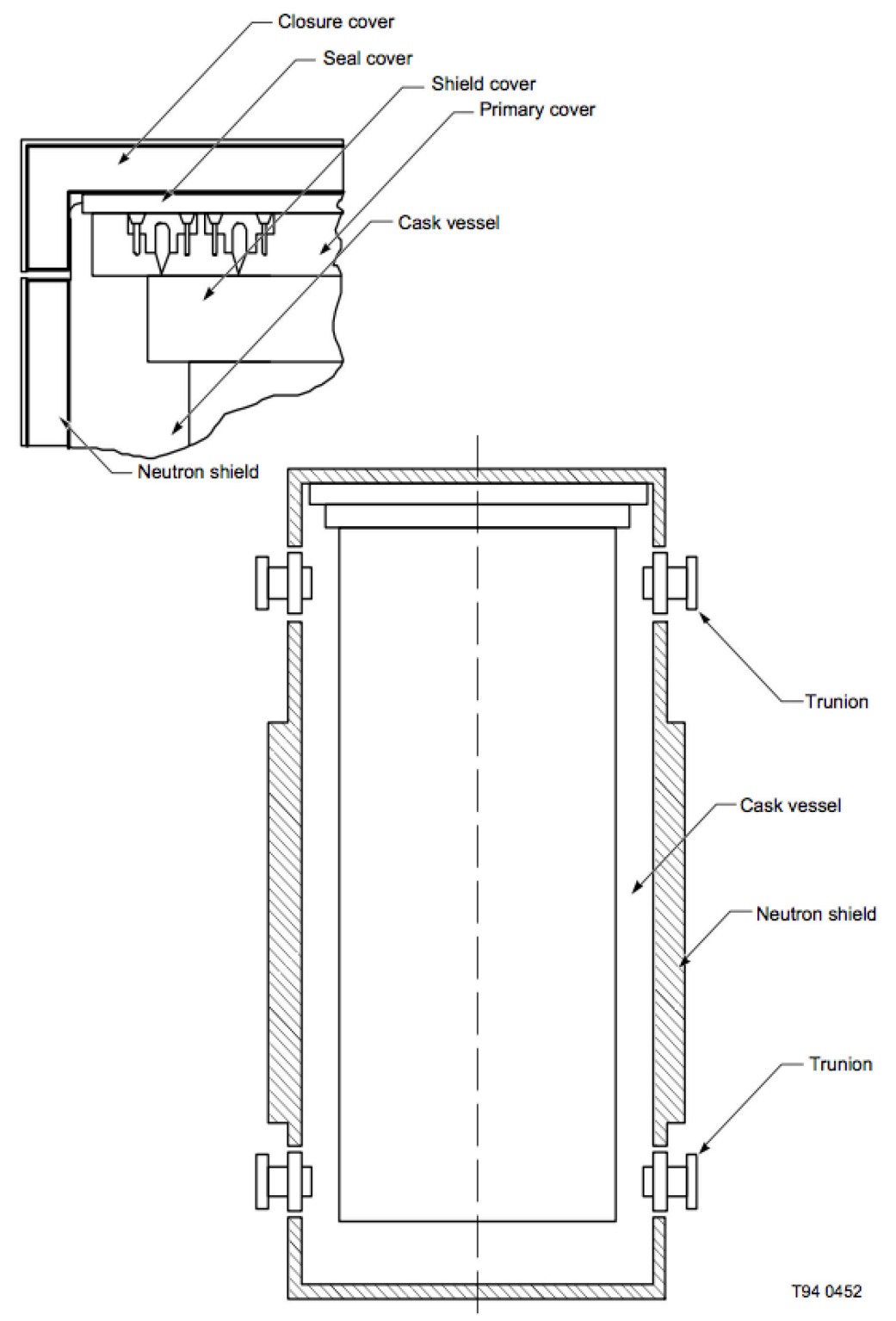

Figure 4. MC-10 cask schematic. 
Table 3. MC-10 fuel inventory.

\begin{tabular}{|c|c|c|c|c|c|c|c|}
\hline $\begin{array}{c}\text { Reactor } \\
\text { Name/type }\end{array}$ & $\begin{array}{l}\text { Assembly } \\
\text { Number }\end{array}$ & $\begin{array}{l}\text { Array/Number } \\
\text { Rods }\end{array}$ & $\begin{array}{l}\text { Burnup } \\
\text { MWd/Mt }\end{array}$ & Enrichment & Storage & Interest & Clad Matl \\
\hline \multirow[t]{2}{*}{ Turkey Point } & $\begin{array}{l}6 \text { Assemblies } \\
\text { D09D18 } \\
\text { D16D22 } \\
\text { D34B17 }\end{array}$ & $15 \times 15 / 204$ & 27,863 & 2.833 & $\begin{array}{c}\text { Discharge date } \\
11 / 19 / 77\end{array}$ & $161.3 \mathrm{~L} \times 8.43 \times 8.43$ & $\mathrm{Zr}-4$ \\
\hline & & & & & & Fuel L 144 & \\
\hline Surry & $\begin{array}{l}12 \\
\text { Assemblies } \\
\text { A49L08 } \\
\text { V03V10 } \\
\text { V16V18 } \\
\text { V22V26 } \\
\text { W23 } \\
\text { W30 } \\
\text { W37 } \\
\text { W45 }\end{array}$ & $15 \times 15 / 204$ & 30,557 & 2.56 & $11 / 06 / 81$ & $520.68 \mathrm{~kg} \mathrm{UO} 2 /$ assy & $\mathrm{Zr}-4$ \\
\hline
\end{tabular}




\subsection{VSC-17 Ventilated Storage Cask}

The Sierra Pacific Nuclear VSC-17 cask is a ventilated concrete shield annulus with internal canister design that is a scaled-down version of the VSC-24, 18 of which are deployed at Palisades, in Michigan. The concrete shield was constructed on-site at INEL Test Area North and the basket loaded in the hot shop. The scale-down was required by the size of the cask mover that was in use at the TAN-791 pad and TAN-607 hot shop. To be able to move loaded cask from the hot shop to the storage pad inside the concrete shield, the accommodations had to be made to be able to use the existing straddle carrier. No transfer cask was used to move the MSB to the shield annulus on the pad.

The cask shield portion (Ventilated Concrete Cask) is constructed of 24 inches thick reinforced concrete that is formed around a 3.5" thick steel inner shell. The concrete and steel has four each lower (intake) and upper (exhaust) ventilation ports oriented at 90 degrees around the circumference. These have full width vertical offsets to prevent radiation shine from the contents. The vents are also steel lined, providing a form around which the concrete was poured.

The Multi-assembly Sealed Basket (MSB) is constructed of carbon steel (pressure vessel steel per SAR-112) coated with an inorganic radiation resistant coating to prevent oxidation. It. has a shell thickness of 0.5 inch and incorporates shielding into the top lid, which is constructed of a sandwich of 4.5 inch thick and 6 inch thick steel plates, between which a 2 inch thick layer of neutron shielding is placed. The lid is sealed with two O-rings, one metal and one ethylene propylene diene monomer (EPDM) elastomer. Approximate total weight at full capacity is 106 tons.

The VSC-17 contains 17 DRCT containers filled with 34 consolidated PWR assemblies from Turkey Point and Surry. Generically, these canisters are 408 rods in the same volume as 204 would in and unconsolidated assembly. The canisters are a 2 piece shell design with tab-slot interlock on the cover as shown in Figure 5 below. 


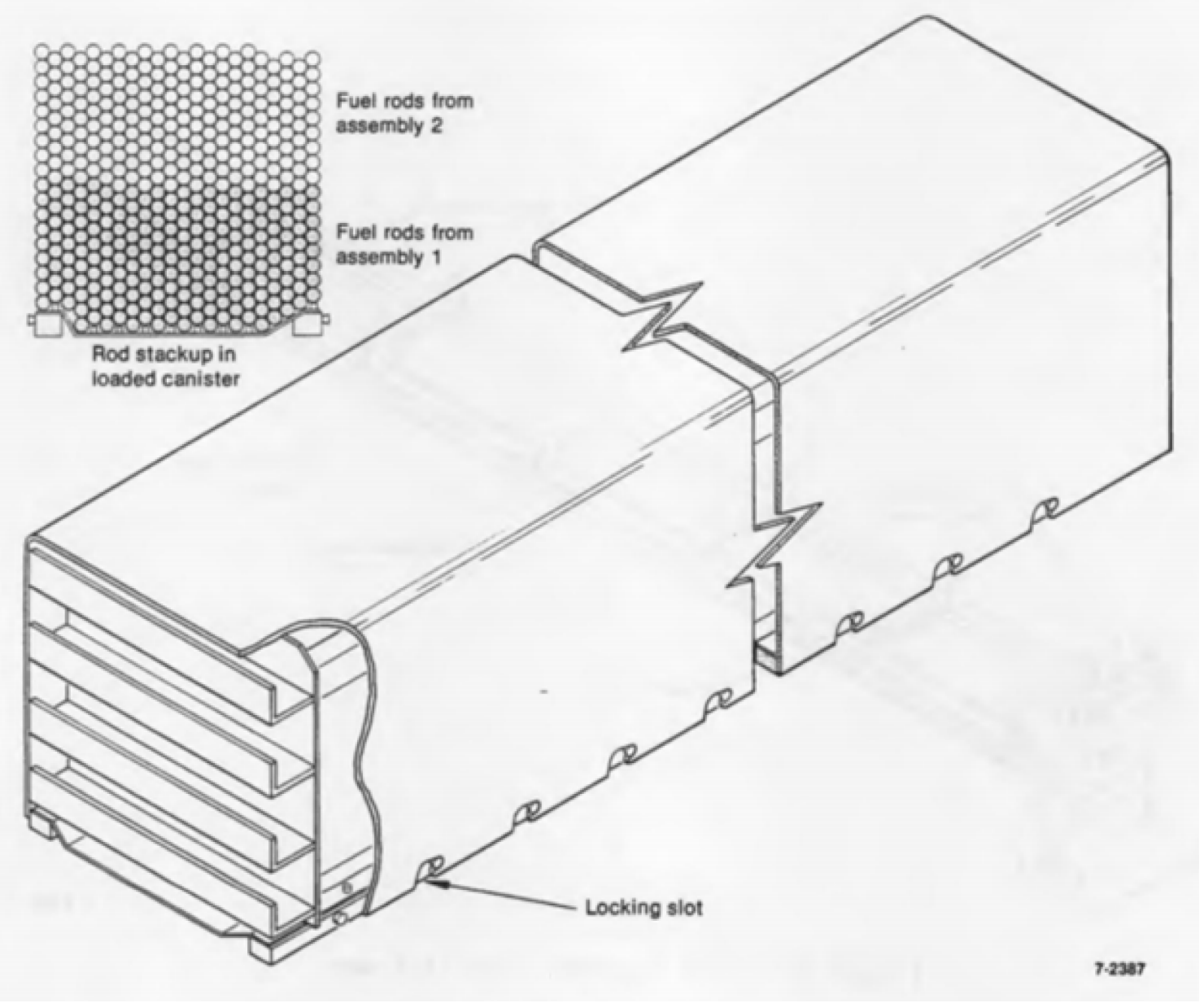

Figure 5. Dry Rod Consolidation Technology DRCT canister (EGG-WM-8059 p 132). 
General cask configuration is shown in Figure 6 below.

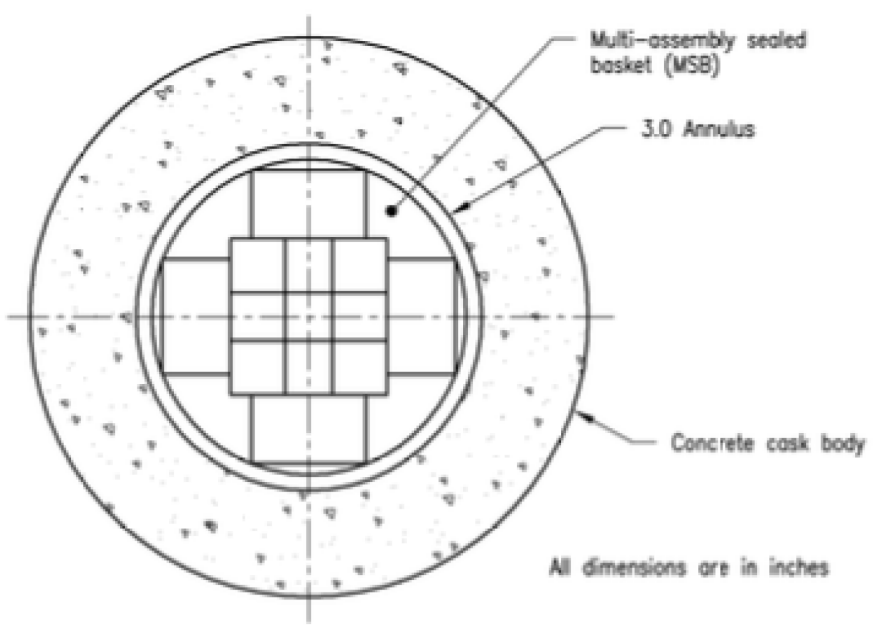

Section A-A

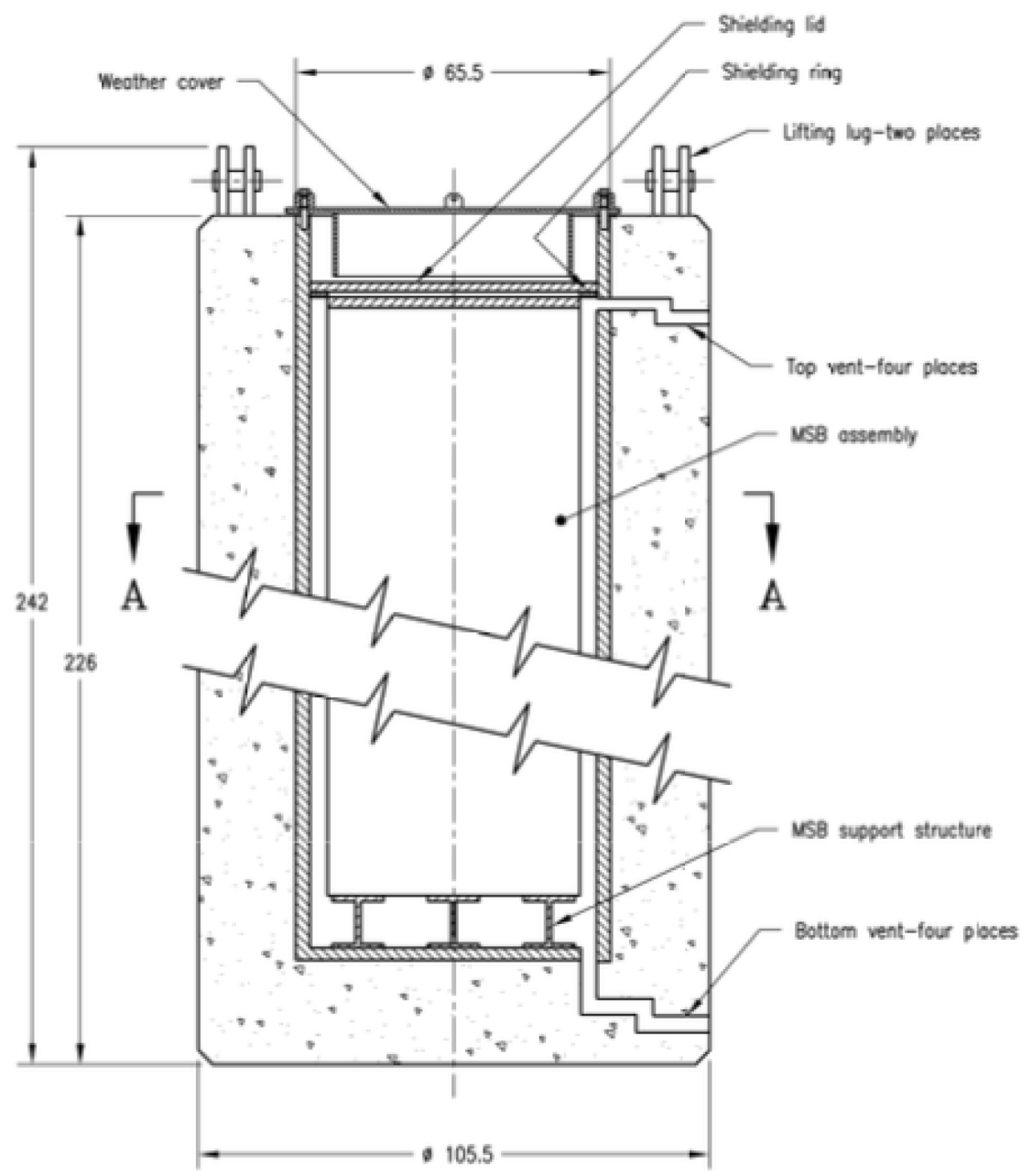

Figure 6. Schematic representation of VSC-17 Cask. 
Table 4. VSC-17 DRCT fuel contents.

\begin{tabular}{|c|c|c|c|c|c|c|c|}
\hline $\begin{array}{c}\text { Reactor } \\
\text { Name/type }\end{array}$ & $\begin{array}{l}\text { Assembly } \\
\text { Number }\end{array}$ & $\begin{array}{l}\text { Array/Number } \\
\text { Rods }\end{array}$ & $\begin{array}{l}\text { Burnup } \\
\text { MWd/Mt }\end{array}$ & Enrichment & Storage & $\begin{array}{c}\text { Interest } \\
\text { Alt Assembly } \\
\text { No. Rods }\end{array}$ & $\begin{array}{c}\text { Clad } \\
\text { Material }\end{array}$ \\
\hline $\begin{array}{l}\text { Turkey } \\
\text { Point Surry } \\
\text { /PWR } \\
\end{array}$ & & & & & $\begin{array}{l}\text { DRCT Canister is } 159.71 \text { " long } \\
\text { by } 8.5 \times 8.5\end{array}$ & $\begin{array}{l}\text { DRCT } \\
2 \text { piece SST shell }\end{array}$ & $\mathrm{Zr}-4$ \\
\hline DRCT 02 & $\begin{array}{l}\text { LM041S } \\
\text { LM041X }\end{array}$ & 407 & 29987 & & $11 / 6 / 81$ & $\begin{array}{l}\text { W44 } 204 \\
\text { W46 } \\
203 \\
\text { Surry } \\
\end{array}$ & \\
\hline $\begin{array}{l}\text { DRCT } \\
03\end{array}$ & $\begin{array}{l}\text { LM040T } \\
\text { LM0419 }\end{array}$ & 407 & 29987 & & $11 / 6 / 81$ & $\begin{array}{l}\text { W17 } 204 \\
\text { W28 } \\
203 \\
\text { Surry }\end{array}$ & \\
\hline $\begin{array}{l}\text { DRCT } \\
04\end{array}$ & $\begin{array}{l}\text { LM0411 } \\
\text { LM0415 } \\
\text { LM041B }\end{array}$ & 409 & 30521 & & $11 / 6 / 81$ & $\begin{array}{l}\text { W27 W34 } \\
\text { all } \\
\text { W46 } \\
1 \\
\text { S }\end{array}$ & \\
\hline $\begin{array}{l}\text { DRCT } \\
06\end{array}$ & $\begin{array}{l}\text { LM040U } \\
\text { LM040V }\end{array}$ & 408 & 29795 & & $11 / 6 / 81$ & $\begin{array}{l}\text { W16 } \\
\text { W19 S }\end{array}$ & \\
\hline $\begin{array}{l}\text { DRCT } \\
07\end{array}$ & $\begin{array}{l}\text { LM040P } \\
\text { LM0410 }\end{array}$ & 408 & 29795 & & $11 / 6 / 81$ & $\begin{array}{l}\text { W02 } \\
\text { W10 S }\end{array}$ & \\
\hline \begin{tabular}{|l|} 
DRCT \\
08 \\
\end{tabular} & $\begin{array}{l}\text { LM0418 } \\
\text { LM0426 }\end{array}$ & 408 & 29795 & & $11 / 6 / 81$ & $\begin{array}{l}\text { W49 } \\
\text { W52 S }\end{array}$ & \\
\hline $\begin{array}{l}\text { DRCT } \\
09\end{array}$ & $\begin{array}{l}\text { LM041Z } \\
\text { LM040R }\end{array}$ & 408 & 29987 & & $11 / 6 / 81$ & $\begin{array}{l}\text { W38 } \\
\text { W01 S }\end{array}$ & \\
\hline $\begin{array}{l}\text { DRCT } \\
10\end{array}$ & $\begin{array}{l}\text { LM0144 } \\
\text { LM0147 } \\
\text { LM0419 }\end{array}$ & 409 & 28430 & & $11 / 30 / 79$ & $\begin{array}{l}\text { D06 } \\
\text { D15 } \\
\text { All TP } \\
\text { W28 1 S }\end{array}$ & \\
\hline $\begin{array}{l}\text { DRCT } \\
11\end{array}$ & $\begin{array}{l}\text { LM014P } \\
\text { LM014Q }\end{array}$ & 408 & 28430 & & $11 / 15 / 79$ & $\begin{array}{l}\text { D35 } \\
\text { D40 TP }\end{array}$ & \\
\hline $\begin{array}{l}\text { DRCT } \\
12\end{array}$ & $\begin{array}{l}\text { LM0140 } \\
\text { LM0411 } \\
\text { LM0151 }\end{array}$ & 408 & 28430 & & $12 / 12 / 79$ & $\begin{array}{l}\text { D01 } \\
\text { D04 } \\
\text { D46 1 } \\
\text { TP }\end{array}$ & \\
\hline
\end{tabular}


Table 4. (continued).

\begin{tabular}{|c|c|c|c|c|c|c|c|}
\hline $\begin{array}{c}\text { Reactor } \\
\text { Name/type } \\
\end{array}$ & $\begin{array}{c}\text { Assembly } \\
\text { Number }\end{array}$ & $\begin{array}{l}\text { Array/Number } \\
\text { Rods }\end{array}$ & $\begin{array}{c}\text { Burnup } \\
\mathrm{MWd} / \mathrm{Mt}\end{array}$ & Enrichment & Storage & $\begin{array}{c}\text { Interest } \\
\text { Alt Assembly } \\
\text { No. Rods }\end{array}$ & $\begin{array}{c}\text { Clad } \\
\text { Material }\end{array}$ \\
\hline $\begin{array}{l}\text { DRCT } \\
13\end{array}$ & $\begin{array}{l}\text { LM014Y } \\
\text { LM0151 }\end{array}$ & 408 & 28430 & & $10 / 01 / 79$ & $\begin{array}{l}\text { D46 } \\
\text { D47 } \\
\text { TP }\end{array}$ & \\
\hline $\begin{array}{l}\text { DRCT } \\
15\end{array}$ & $\begin{array}{l}\mathrm{N}-37 \\
\mathrm{~N}-17 \\
\mathrm{~B}-03\end{array}$ & 410 & 27035 & & $04 / 22 / 76$ & $\begin{array}{l}\text { N17 } \\
\text { N37 } \\
\text { All S } \\
\text { B03 } 2 \text { TP }\end{array}$ & \\
\hline $\begin{array}{l}\text { DRCT } \\
16\end{array}$ & $\begin{array}{l}\text { N-16 } \\
\text { N-35 } \\
\text { B-03 }\end{array}$ & 410 & 26824 & & $04 / 22 / 76$ & $\begin{array}{l}\text { N16 } \\
\text { N35 } \\
\text { All S } \\
\text { B03 TP } \\
\end{array}$ & \\
\hline $\begin{array}{l}\text { DRCT } \\
17\end{array}$ & $\begin{array}{l}\text { LMOOUJ } \\
\text { LMOOUT }\end{array}$ & 407 & 35436 & & $02 / 04 / 79$ & \begin{tabular}{|l} 
R34 all \\
R35 \\
$203 \mathrm{~S}$ \\
\end{tabular} & \\
\hline \begin{tabular}{|l} 
DRCT \\
21 \\
\end{tabular} & $\begin{array}{l}\mathrm{N}-05 \\
\mathrm{~N}-11\end{array}$ & 408 & 28824 & & $04 / 22 / 76$ & $\begin{array}{l}\text { N05 } \\
\text { N11 All S }\end{array}$ & \\
\hline \begin{tabular}{|l} 
DRCT \\
23 \\
\end{tabular} & \begin{tabular}{|l} 
LM040Q \\
LMOOVR
\end{tabular} & 408 & 28292 & & $11 / 06 / 81$ & $\begin{array}{l}\text { W09 } \\
\text { R41 All S }\end{array}$ & \\
\hline $\begin{array}{l}\text { DRCT } \\
24\end{array}$ & $\begin{array}{l}\text { B-02 } \\
\text { LMOOU0 } \\
\text { LMOOTN }\end{array}$ & 410 & 35436 & & $02 / 04 / 79$ & \begin{tabular}{|l} 
R01 \\
R15 \\
all \\
B03 2 \\
TP \\
\end{tabular} & \\
\hline
\end{tabular}




\section{$3.5 \quad \mathrm{TN}-24 \mathrm{P}$}

The Transnuclear (TN)-24P cask is constructed of 10.2 inch thick forged steel with primary overall length of $16.6 \mathrm{ft}$ and $6.6 \mathrm{ft}$ outer diameter. The cavity is $13.8 \mathrm{ft}$ long and $4.8 \mathrm{feet}$ in diameter, making it able to contain 24 PWR assemblies. It is closed with a primary bolted steel lid which incorporates a neutron shield. The lid is sealed with two metallic O-rings. The protective cover is sealed with an elastomer O-ring and 3 pressure transducers monitor pressure between the primary lid and cover for leak detection.

The fuel basket is constructed of $1 \mathrm{~cm}$ thick copper coated borated ( $3 \mathrm{wt} \%)$ aluminum and steel plate. The forged design is rated for a maximum pressure of $250 \mathrm{psi}(17 \mathrm{~atm})$. A schematic illustration of the cask is shown in Figure 7 below

The contents of the TN-24 P include 7 DRCT canisters (previously described for the VSC-17) and 12 positions contain LOFT assemblies. The fuel data is shown in tabular form in Table 6 . The LOFT fuel assemblies are 70.38 total length $\times 8.426 \times 8.426$ square.

A1 Center contains Zr-4 clad 204 rods.

$\begin{array}{ll}\text { A2 Center } & 204 \\ \text { F1 Center } & 204 \\ \text { A3 Center } & 204 \\ \text { B Square (3x) } & 204 \\ \text { D Square } & 204 \\ \text { C Corner }(2 x) & 70 \\ \text { E Corner }(2 x) & 70\end{array}$




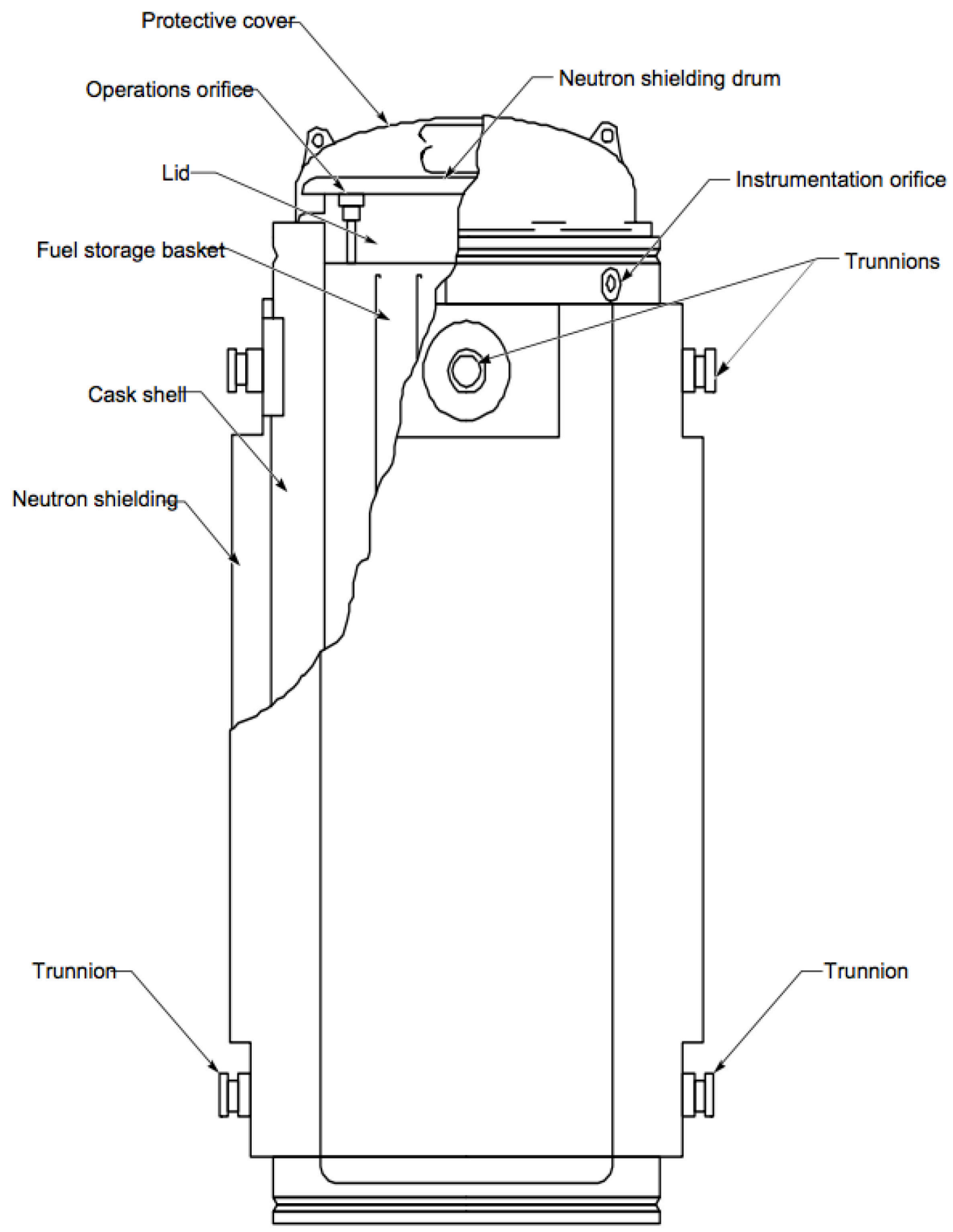

Figure 7. TN-24P. 
Table 5. TN-24P contents.

\begin{tabular}{|c|c|c|c|c|c|c|c|}
\hline $\begin{array}{c}\text { Reactor } \\
\text { Name/ type }\end{array}$ & $\begin{array}{l}\text { Assembly } \\
\text { Number }\end{array}$ & $\begin{array}{l}\text { Array/Number } \\
\text { Rods }\end{array}$ & $\begin{array}{c}\text { Burnup } \\
\text { GWd/Mt }\end{array}$ & Enrichment & Storage & $\begin{array}{c}\text { Interest } \\
\text { No. Rods }\end{array}$ & Clad Matl \\
\hline $\begin{array}{l}\text { Surry } \\
\text { Turkey Point } \\
\text { /PWR }\end{array}$ & & & & & $\begin{array}{l}\text { DRCT Canister is } 159.71 \text { " long } \\
\text { by } 8.5 \times 8.5\end{array}$ & $\begin{array}{l}\text { DRCT } \\
2 \text { piece SST shell }\end{array}$ & $\mathrm{Zr}-4$ \\
\hline $\begin{array}{l}\text { DRCT } \\
05\end{array}$ & $\begin{array}{l}\text { R09 } \\
\text { R18 }\end{array}$ & 408 & $\begin{array}{c}35.33 \\
35.4 \\
\end{array}$ & & $02 / 04 / 79$ & $\begin{array}{l}204 \\
204\end{array}$ & \\
\hline $\begin{array}{l}\text { DRCT } \\
14\end{array}$ & $\begin{array}{l}\text { N36 } \\
\text { N04 }\end{array}$ & 399 & 26.82 & & $04 / 22 / 76$ & & \\
\hline $\begin{array}{l}\text { DRCT } \\
18\end{array}$ & $\begin{array}{l}\text { W06 } \\
\text { W13 }\end{array}$ & 408 & 30.52 & & $11 / 06 / 81$ & $\begin{array}{l}204 \\
204\end{array}$ & \\
\hline $\begin{array}{l}\text { DRCT } \\
19\end{array}$ & $\begin{array}{l}\text { B02 } \\
\text { B03 } \\
\text { N04 } \\
\text { N15 }\end{array}$ & 410 & 25.67 & & $10 / 25 / 75$ & $\begin{array}{l}204 \\
204 \\
1 \\
1 \\
\end{array}$ & \\
\hline $\begin{array}{l}\text { DRCT } \\
20\end{array}$ & $\begin{array}{l}\text { N09 } \\
\text { N15 }\end{array}$ & 407 & 26.82 & & $04 / 22 / 76$ & $\begin{array}{l}204 \\
203 \\
\end{array}$ & \\
\hline $\begin{array}{l}\text { DRCT } \\
22\end{array}$ & $\begin{array}{l}\text { B41 } \\
\text { B43 } \\
\text { R41 } \\
\text { R35 } \\
\end{array}$ & 410 & $\begin{array}{l}25.67 \\
25.60\end{array}$ & & $10 / 25 / 75$ & $\begin{array}{l}204 \\
204 \\
1 \\
1 \\
\end{array}$ & \\
\hline $\begin{array}{l}\text { DRCT } \\
25\end{array}$ & $\begin{array}{l}\text { L25 } \\
\text { L04 } \\
\text { N04 } \\
\text { B03 }\end{array}$ & 410 & $\begin{array}{l}27.18 \\
24.53\end{array}$ & & $09 / 09 / 77$ & $\begin{array}{l}204 \\
204 \\
1 \\
1 \\
\end{array}$ & \\
\hline
\end{tabular}




\subsection{NuPac 125-B 2}

Three Nuclear Pacific (NuPac) 125 B cask(s) were developed for shipment of the TMI 2 debris from Pennsylvania to Idaho. Two are in service inside CPP-666 truck bay where they contain "cats and dogs" of research reactor and test fuel and debris that were either small lots or inconsistent with the UREX process that was used at the Idaho Chemical Processing Plant during its operational era. Only cask 2 is in service on the CPP-2707 pad.

The cask consist of inner and outer vessels, with lead shielding in the outer vessel. The outer dimensions are 65.5 inches outside dimeter x 207.5 inches long. The vessels are constructed of $304 \mathrm{~L}$ stainless steel, with the outer shell walls (2" thick steel outer, 1 " thick steel inner) filled with 3.9 inches of lead. The bottom of the outer vessel is 7.5 inches thick steel, as is the bolted steel lid. The seal is maintained with 2 neoprene O-rings. The inner vessel is 50.75 inches diameter $\times 192.25$ inches tall, and incorporates a canister basket with 7 positions that have 15.5 inch sleeves that originally fit the 14" diameter TMI-2 debris canisters. The inner sleeves have provisions for crush media at top and bottom ends of the sleeves. The void spaces between the sleeves are filled with BISCO NS-2 neutron absorbing concrete.

The inner vessel is shown in Figure 8 and the outer cask vessel is Figure 9 below.

When the NuPac-125B was in service bringing the TMI-2 debris to Idaho by rail, external impact limiters were attached to each end while the casks were transported in the horizontal position.

The contents of the NuPac-125B are primarily debris from historical testing and post-irradiation examination of numerous types of fuel. There are pieces from Halden MOX test rods which came from one or the other of the two Halden assemblies that INEL received under the auspices of the USNRC in 1974. The IFA-239 assembly achieved a burnup of 40,000 MWd/t, which is referred to as high burnup fuel in the available documentation. The TMI-2 debris is primarily mounted metallurgical samples. This material was not included in the TMI-1 CPP-1774 NuHOMS debris storage because there were concerns about the amount of organic material in the met mounts. The epoxy used to mount samples was presumed to represent a source for radiolytic hydrogen, so the drying was performed at less than the $600 \mathrm{C}$ that was used for drying the debris that was placed in the NuHOMS system interim storage. The TMI-2 material is placed in two of the original TMI canisters, which are stainless steel with removable tops and external dimensions of 14 inches OD $\times 150$ inches long. The internal cavity is 9 inches square and the void between the square liner and the round canister is filled with lightweight concrete (LICON). The square liner is constructed of concentric stainless steel tubes that encase borated aluminum plates which functions as a criticality control measure. The D- 153 canister is only partially filled, with 5 debris baskets containing samples and scrap to a level of approximately 40 inches. Canister D-388 contains six $8 \times 8 \times 8$ inch baskets in addition to three $8 \times 8 \times 8$ inch baskets that had previously been stored in canister D389.

The volume of epoxy for all of the baskets was calculated to be approximately 78 liters. Other material such as Bakelite, lead/bismuth alloy and low melting point alloys such as Wood's metal $(50 \% \mathrm{Bi}, 25 \% \mathrm{~Pb}, 12.5 \% \mathrm{Sn}, 12.5 \% \mathrm{Cd})$ was used for mounting samples and is present in the baskets of debris.

The tabulated contents of the NuPac 125B are shown in Table 7 below. 


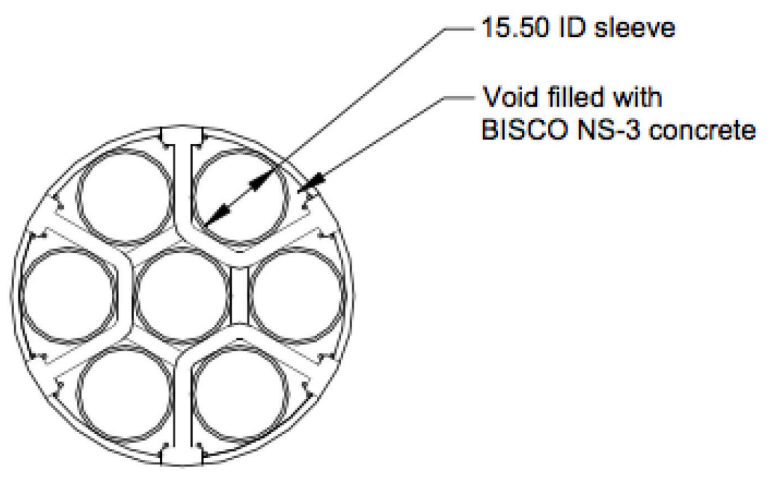

Cross section

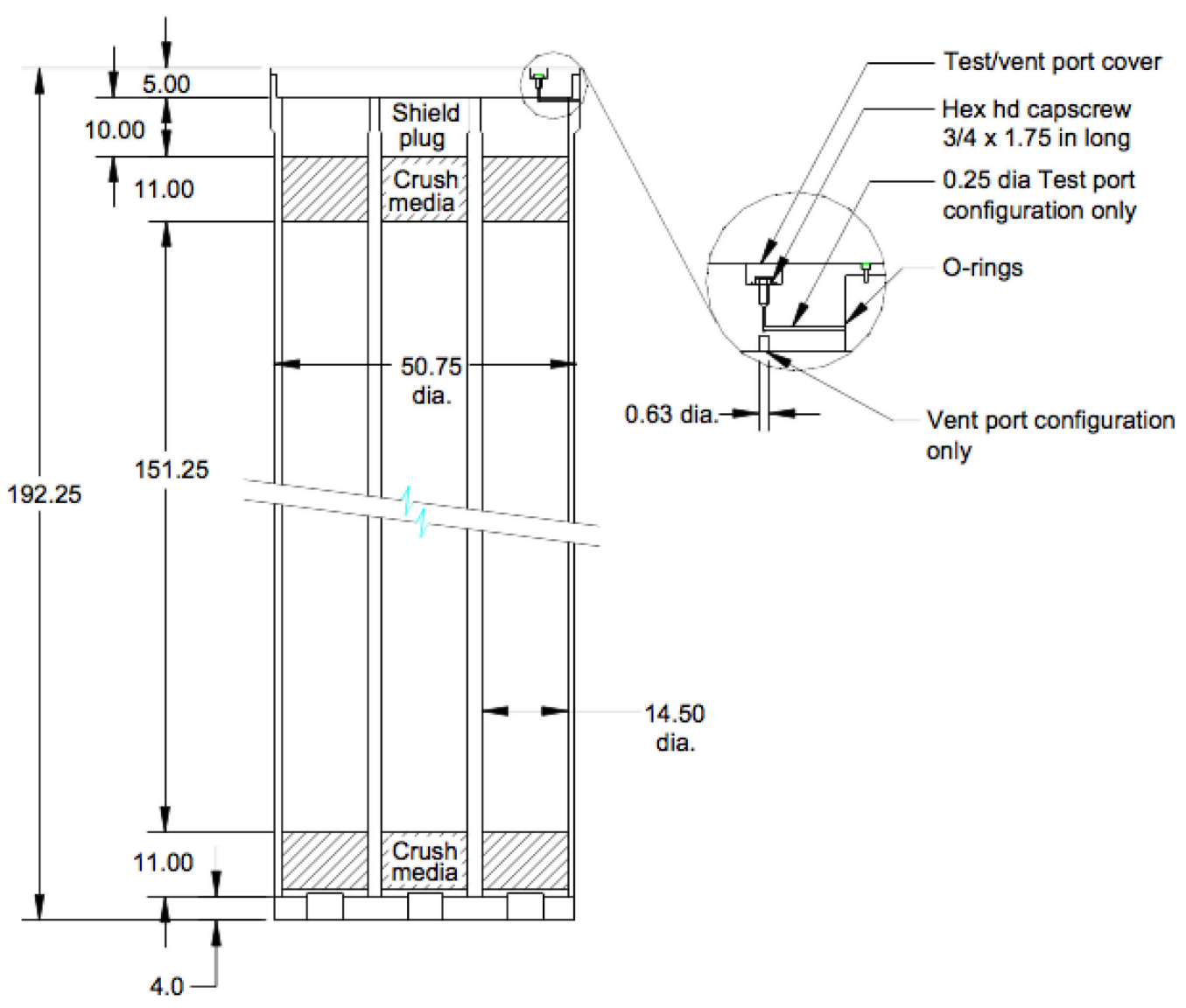

Figure 8. NuPac-125B Inner Vessel. 


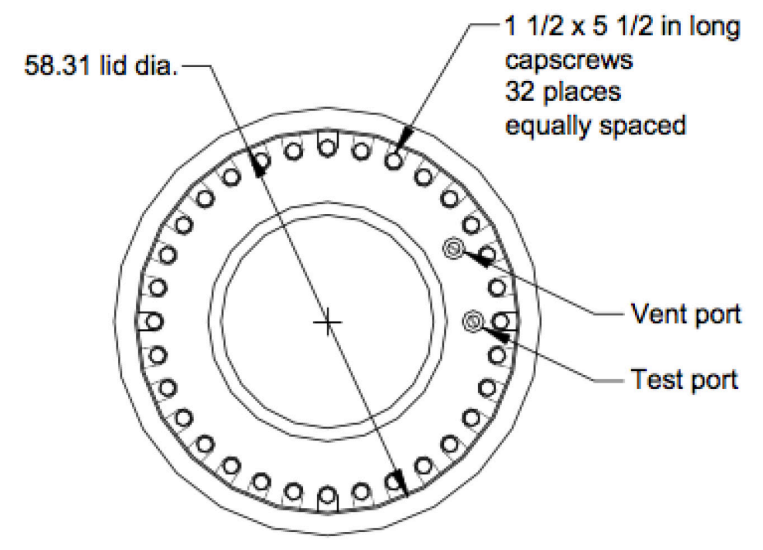

Lid

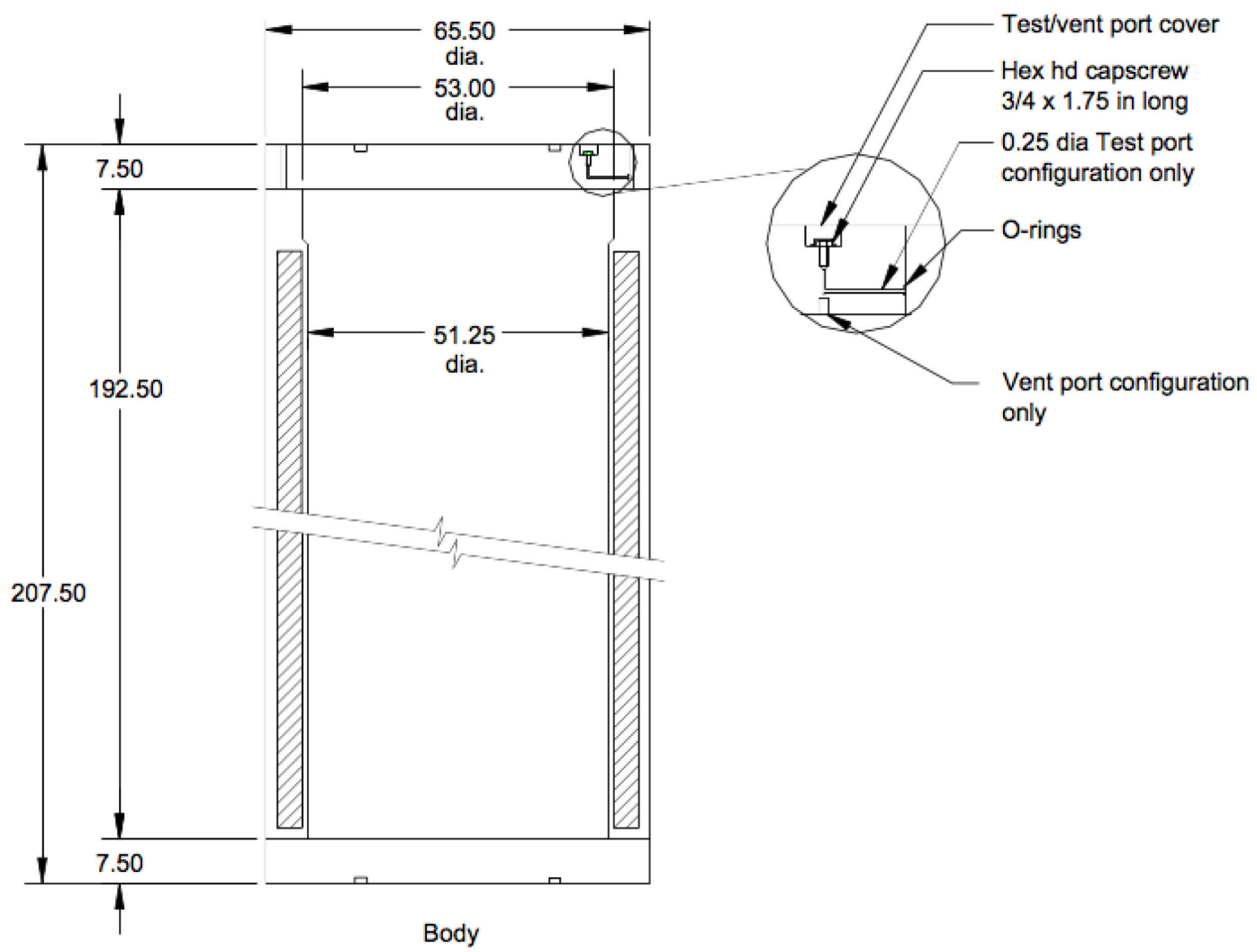

Figure 9. NuPac-125B Outer Vessel. 
Table 6. Tabulated contents of NuPac-125B.

\begin{tabular}{|c|c|c|c|c|c|c|c|}
\hline $\begin{array}{c}\text { Reactor } \\
\text { Name/type }\end{array}$ & $\begin{array}{c}\text { Assembly } \\
\text { Number }\end{array}$ & $\begin{array}{l}\text { Array/Number } \\
\text { Rods }\end{array}$ & $\begin{array}{c}\text { Burnup } \\
\text { GWd/Mt }\end{array}$ & Enrichment & Storage & $\begin{array}{c}\text { Interest } \\
\text { No. Rods }\end{array}$ & Clad Matl \\
\hline Halden & \begin{tabular}{|l|} 
IFA-226 \\
IFA-239 \\
\end{tabular} & 12 rods & $\begin{array}{c}40 \\
12.3 \\
\end{array}$ & $9.5 \mathrm{wt} \% \mathrm{Pu} / \mathrm{DUO} 2$ & & 33 " long & \\
\hline HB Robinson & & & & $\begin{array}{c}1.85 \\
2.56 \\
3.1 \\
\end{array}$ & & & \\
\hline Dresden 1 & & & & & & Possibly present & \\
\hline TMI-2 & \begin{tabular}{|l} 
Debris \\
Canisters \\
D-153 \\
D-388 \\
\end{tabular} & & & Weighted average $2.54 \%$ & 5 baskets $8 " \times 8.25 " \times 8 "$ & & $\begin{array}{l}316 \text { SS can } \\
14 \text { "OD } \times \\
149.75 \text { "L }\end{array}$ \\
\hline LOFT & FP-2 & & & $9.74 \mathrm{wt} \%$ & $\begin{array}{l}6 \text { Cans cut up assy } \\
3 \text { cans met mounts }\end{array}$ & $\begin{array}{l}9 " \times 9 \text { " SST canister } \\
\text { filled with epoxy and } \\
\text { sectioned into slabs }\end{array}$ & $\mathrm{Zr}-4$ \\
\hline
\end{tabular}



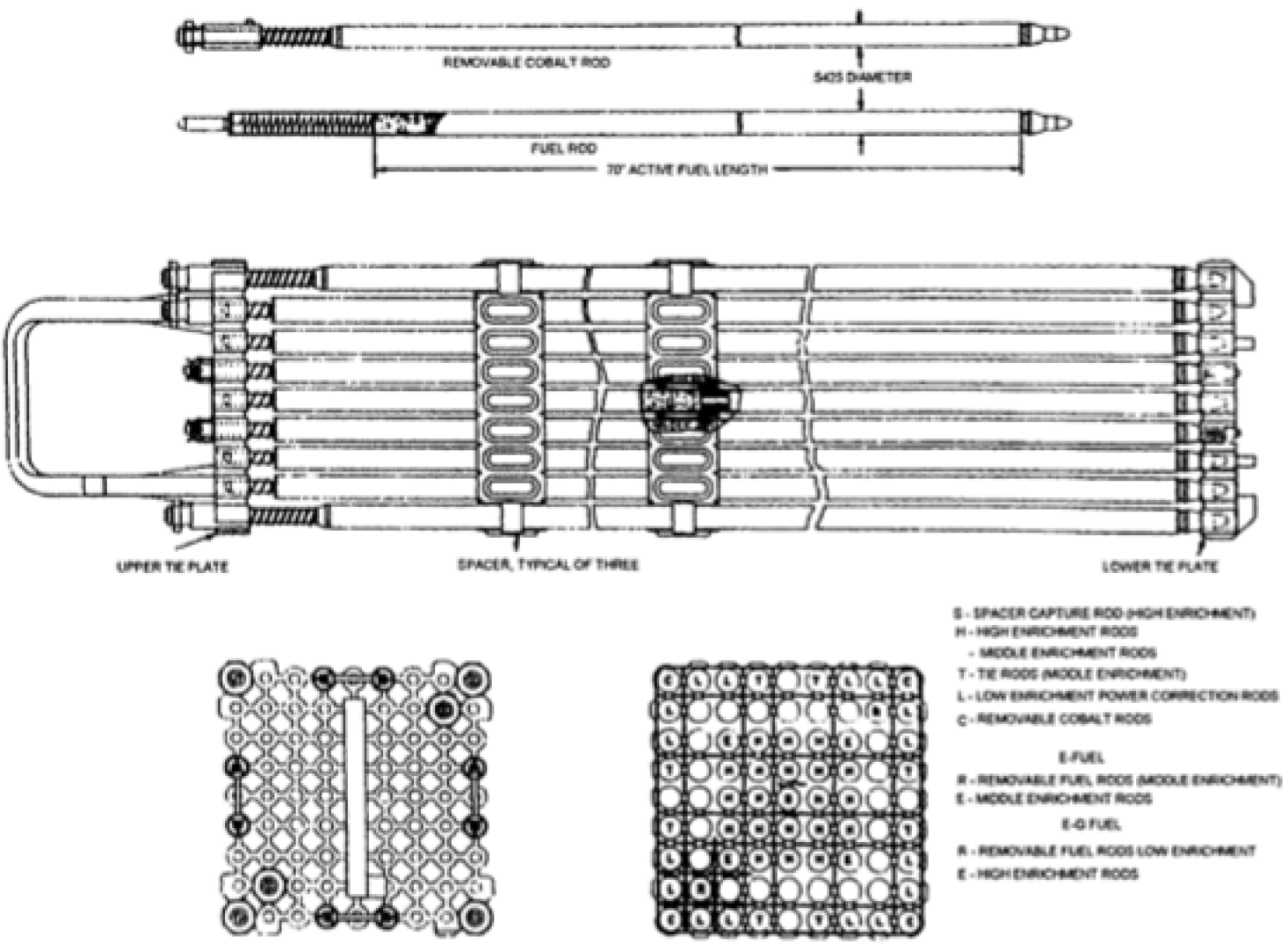

BS ROCK PONT E AND E-O FUEL.

Figure 10. BRP $9 \times 9$ Rod Assembly

Robert Emmet Ginna Power Plant was a design for 420 MW electric output. It uses 121 fuel assemblies with 14 x14 rod arrays using 16 guide tubes for control rods and one for instrumentation. The assembly characteristics are shown in Table 8, also from EDF-1752. The assembly structure is shown in Figure 11. 


\section{REG FUEL ASSEMBLY PHYSICAL CHARACTERISTICS}

Fuel Assembly

Rod Array

Rods per Assembly

$14 \times 14$

Instrument/Control Rod Guide Tubes

179

Rod Pitch

17

Rod O.D.

Clad Thickness

Clad Material

Diametral Gap

UO2 Pellet Diameter

Pellet density, \% theoretical

Assembly length

Length with control rod

Active fuel length

Initial uranium loading

Initial enrichment

0.556 inch

0.422 inch

0.024 inch

$\mathrm{Zr}-4$

0.007 inch

0.367 inch

$90 \%$

160.875 inches

161.380 inches

144 inches

$382.18 \mathrm{Kg}$

$3.473 \%$ U-235

Guide Tubes, Stainless Steel

Quantity

OD

16

ID

0.5375 in.

0.5075 in.

Instrument Tube, Stainless Steel

OD

0.422 in.

ID

0.3455 in.

Burnable Poison Rod

Outer Stainless Steel Tube OD

Outer Stainless Steel Tube ID

0.432 in.

Inner Stainless Steel Tube OD

0.393 in.

0.312 in.

$0.268 \mathrm{in}$.

Inner Stainless Steel Tube ID

Annular poison material

Borosilicate glass

Length of poison material

142.01

Control Rod

Stainless Steel Tube OD

0.431 in.

Stainless Steel Tube ID

0.393 in.

Poison Material

80Ag15In5Cd

Table 8. R.E. Ginna Fuel Characteristics 


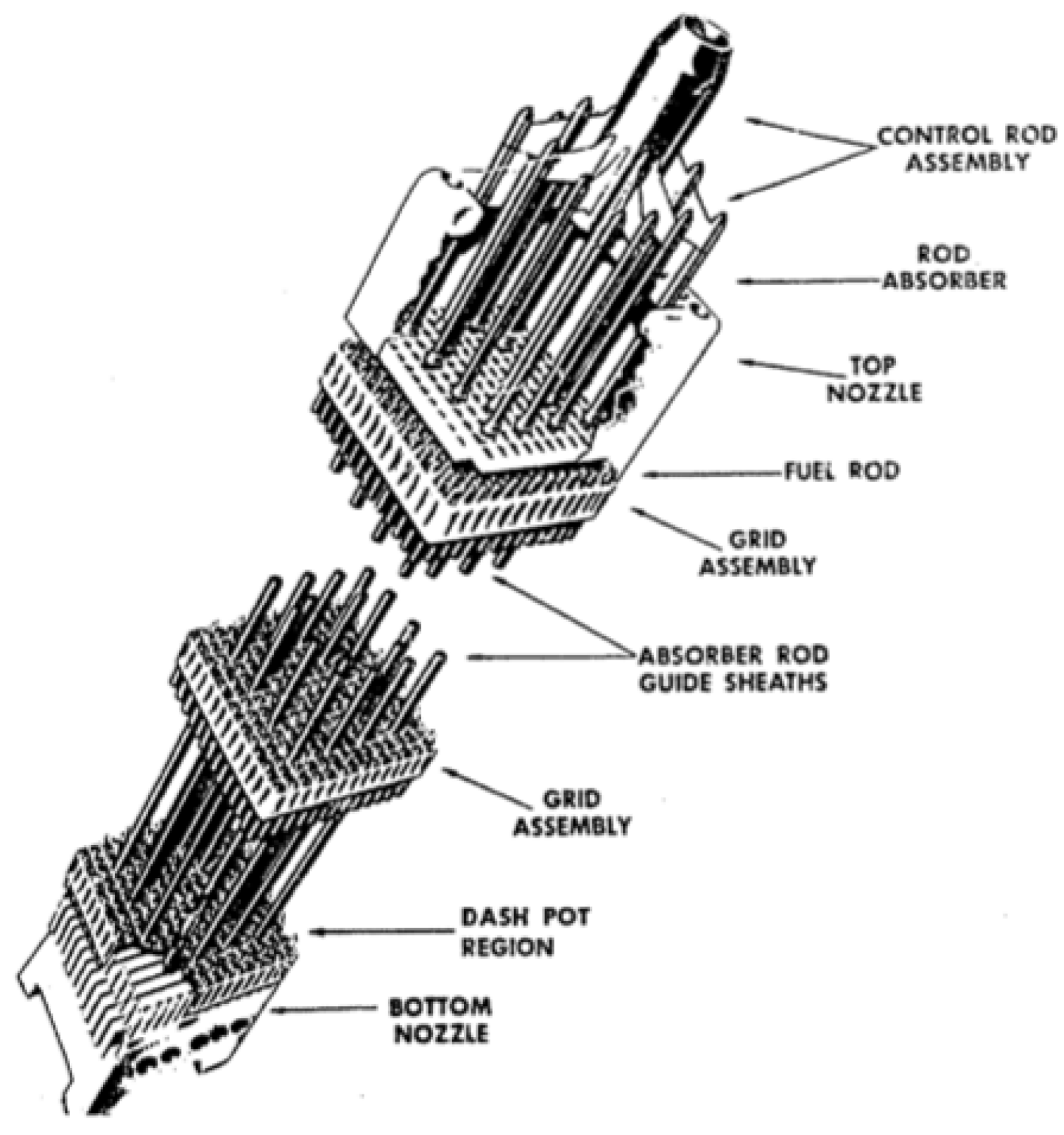

Figure 11. R.E. Ginna Assembly Without Rods

The assembly number and burnup data are shown in Table 9 below. 


\begin{tabular}{|c|c|c|c|}
\hline \multirow[b]{2}{*}{$\begin{array}{c}\text { Assembly } \\
\text { Identification }\end{array}$} & \multicolumn{2}{|c|}{ REG Fuel Assembly Nuclear Data } & \\
\hline & $\begin{array}{c}\text { Burn-up } \\
\text { (MWD/MTU) }\end{array}$ & Discharge Date & \\
\hline $\mathrm{CO9}$ & 5592 & $3 / 71$ & \\
\hline $\mathrm{CO} 2$ & 8516 & $3 / 71$ & \\
\hline C39 & 5875 & $3 / 71$ & \\
\hline $\mathrm{C} 04$ & 8703 & $3 / 71$ & \\
\hline $\mathrm{C} 24$ & 6069 & $3 / 71$ & \\
\hline $\mathrm{Cl1}$ & 8815 & $3 / 71$ & \\
\hline $\mathrm{Cos}$ & 8577 & $3 / 71$ & \\
\hline $\mathrm{C} 07$ & 8561 & $3 / 71$ & \\
\hline $\mathrm{C} 20$ & 5899 & $3 / 71$ & " \\
\hline $\mathrm{C} 06$ & 8403 & $3 / 71$ & \\
\hline $\mathrm{C} 08$ & 8858 & $3 / 71$ & \\
\hline $\mathrm{C01}$ & 8712 & $3 / 71$ & \\
\hline & 7715 & & \\
\hline $\mathrm{C} 26$ & 9776 & $5 / 72$ & \\
\hline C34 & 9568 & $5 / 72$ & \\
\hline $\mathrm{C} 25$ & 9775 & $5 / 72$ & \\
\hline $\mathrm{C} 18$ & 9774 & $5 / 72$ & \\
\hline C37 & 9622 & $5 / 72$ & \\
\hline C35 & 9758 & $5 / 72$ & \\
\hline & 9712 & & \\
\hline $\mathrm{C} 12$ & 13748 & $5 / 72$ & \\
\hline $\mathrm{C} 13$ & 13909 & $5 / 72$ & \\
\hline C29 & 10321 & $5 / 72$ & \\
\hline C28 & 10269 & $5 / 72$ & \\
\hline C33 & 10450 & $5 / 72$ & \\
\hline C36 & 9812 & $5 / 72$ & \\
\hline $\mathrm{C} 27$ & 9869 & $5 / 72$ & \\
\hline C30 & 11188 & $5 / 72$ & \\
\hline $\mathrm{C} 21$ & 9899 & $5 / 72$ & \\
\hline $\mathrm{C} 22$ & 12432 & $5 / 72$ & \\
\hline $\mathrm{C} 03$ & 10195 & $5 / 72$ & \\
\hline $\mathrm{C} 16$ & 13998 & $5 / 72$ & \\
\hline $\mathrm{C} 23$ & 14293 & $5 / 72$ & \\
\hline $\mathrm{C} 19$ & 13763 & $5 / 72$ & \\
\hline $\mathrm{C} 17$ & 13770 & $5 / 72$ & \\
\hline $\mathrm{Cl} 4$ & 10059 & $5 / 72$ & \\
\hline C32 & 10348 & $5 / 72$ & \\
\hline $\mathrm{C} 40$ & 10526 & $5 / 72$ & \\
\hline C31 & 13842 & $5 / 72$ & \\
\hline $\mathrm{C} 15$ & 10182 & $5 / 72$ & \\
\hline C38 & 10572 & $5 / 72$ & \\
\hline $\mathrm{C} 10$ & 10385 & $5 / 72$ & \\
\hline & 11537 & & \\
\hline
\end{tabular}

Table 9. REG Assemblies in Storage at INL 
Defects noted during visual inspection included 1) rods with collapsed cladding, 2) pieces of fuel rod missing, 3) holes in the rods, 4) large dents and dimples, 5) small holes, 6) broken rods, 7) rods with missing end plugs, 8) holes up to one-half the rod diameter, 9) rods that were split and bulged, and 10) pinholes. Examples of the defects are shown in the following figures, such as REG assembly C30 which has a cracked top nozzle, and C35 which has a cracked rod.

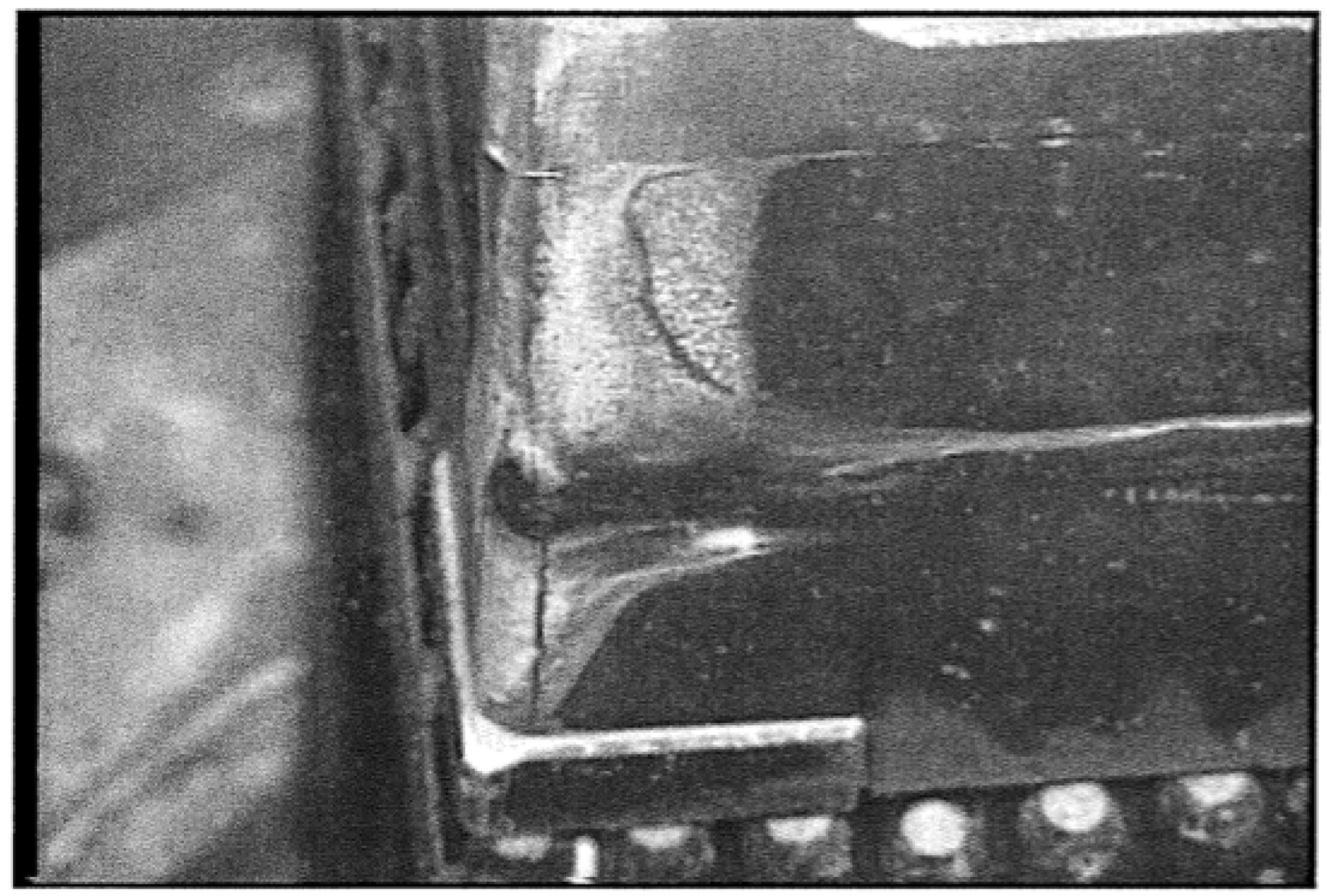

Figure 12. REG Assembly C30 Crack in Corner of Top Nozzle 


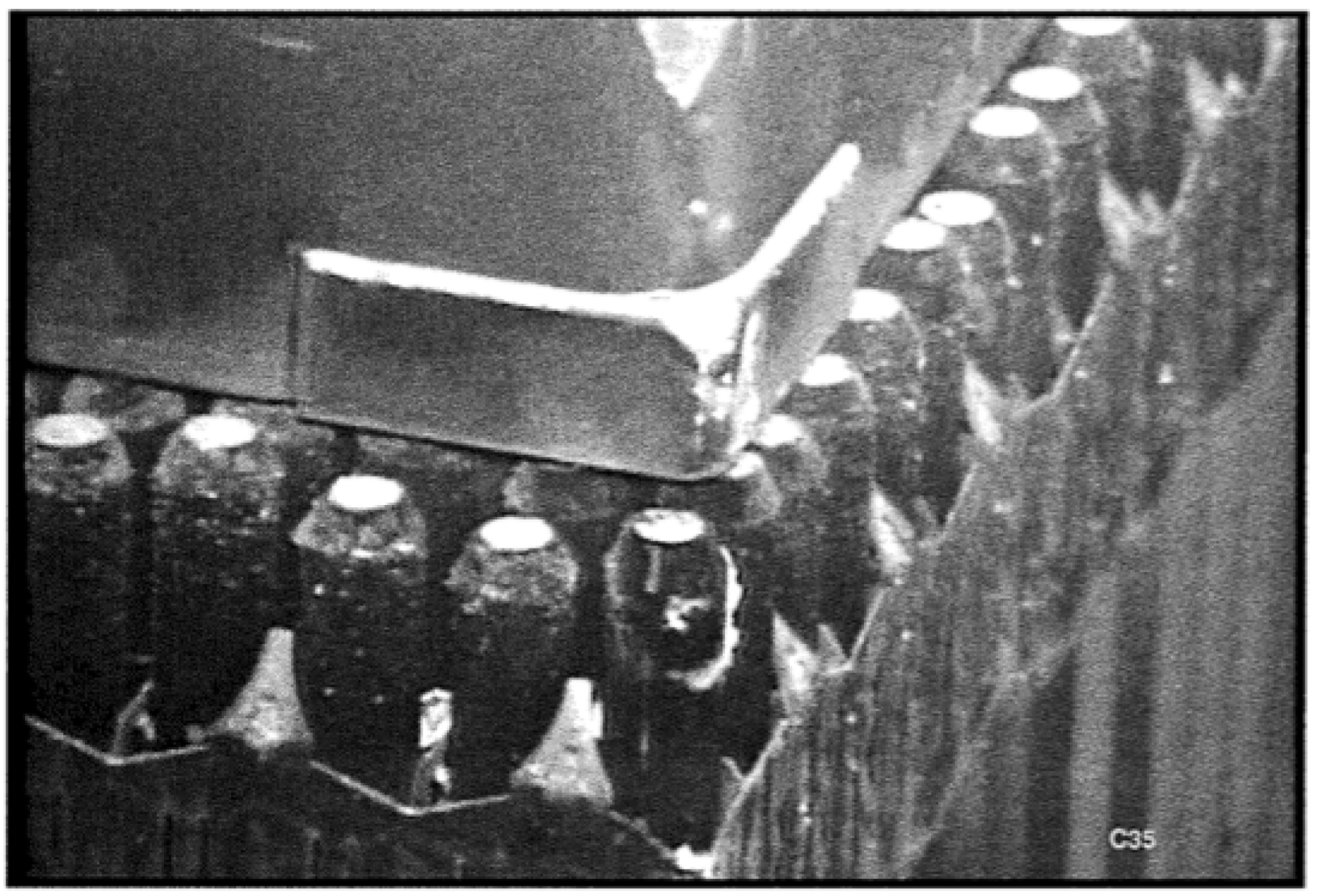

Figure 13. REG Assembly C35 Crack in corner pin

Defects observed in the BRP assemblies include holes in cladding with corrosion deposits that are presumed to be $\mathrm{UO}_{2}(\mathrm{OH})_{2}$ due to its orange color. The cladding is reddish due to adherent crud. These defects are shown in Figures 14 and 15. 


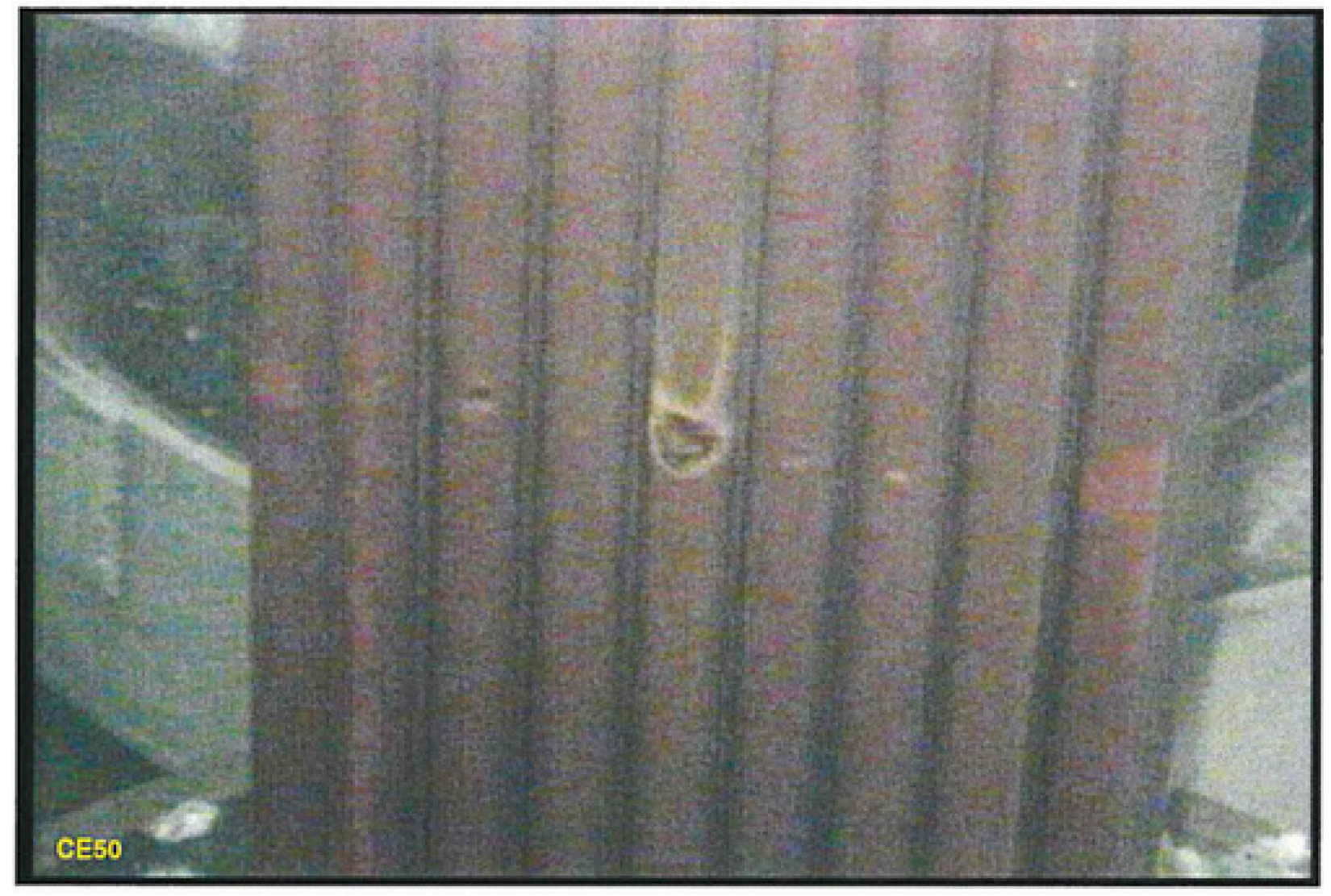

Figure 14. BRP Assembly CE50 Hole in cladding visible as orange deposit, crud is reddish. 


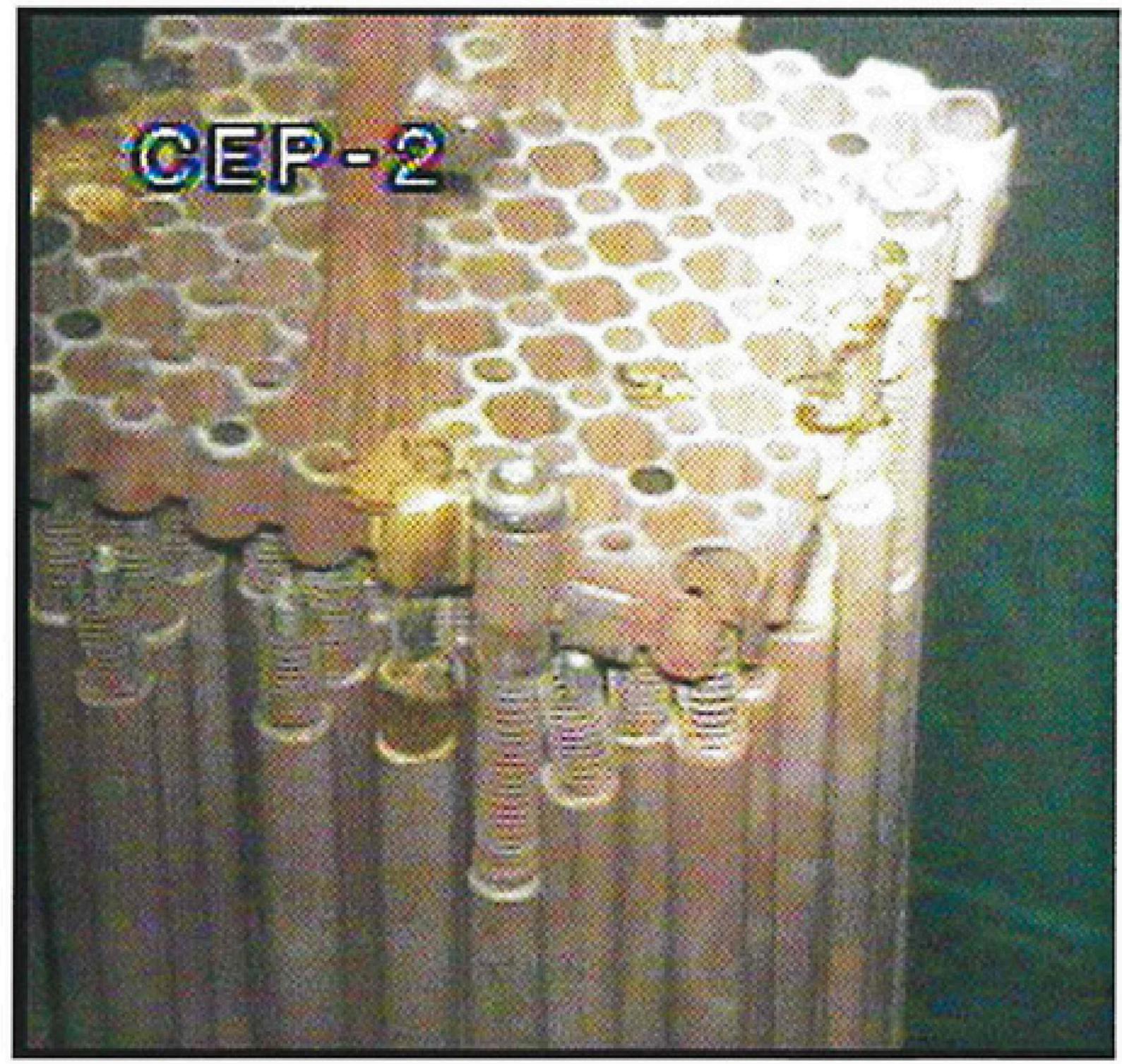

Figure 15. BRP Assembly CEP2 Broken rods with exposed plenum springs and damaged upper tie plate

Crud observed on the two fuel types were of Class I for Big Rock Point BWR fuel and Class IV for the R. E. Ginna PWR. As specified by A. B. Johnson Jr. of Pacific Northwest Laboratory (PNL), Class I is thick hard copper oxide $(\mathrm{CuO})$ crud with embedded particles of magnetite $\left(\mathrm{Fe}_{3} \mathrm{O}_{4}\right)$, while Class IV is typical of early PWRs, generally a nickel ferrite $\left(\mathrm{Ni}_{x} \mathrm{Fe}_{3-\mathrm{x}} \mathrm{O}_{4}\right)$. It was noted that some of the BWR crud, which ranged from 25 to $50 \mathrm{fm}$ becomes less tenaciously bonded during extended wet storage. Crud was alternately referred to as scaling to the extent that it was described as unacceptable.

The fuel assemblies were loaded into the TN-REG and TN-BRP casks, respectively, in April-May 2001, dewatered, and vacuum dried. Drying was done at ambient temperatures ${ }^{1}$ to meet the NUREG 1536 requirement for commercial fuel of holding a 3 torr vacuum for 30 minutes following isolation from the 
vacuum pump. The 3 torr value corresponds to 1 mole of water in the void volume of the cask. The filled shipping casks were stored on a rail siding at WVDP until their shipment to the INEEL.

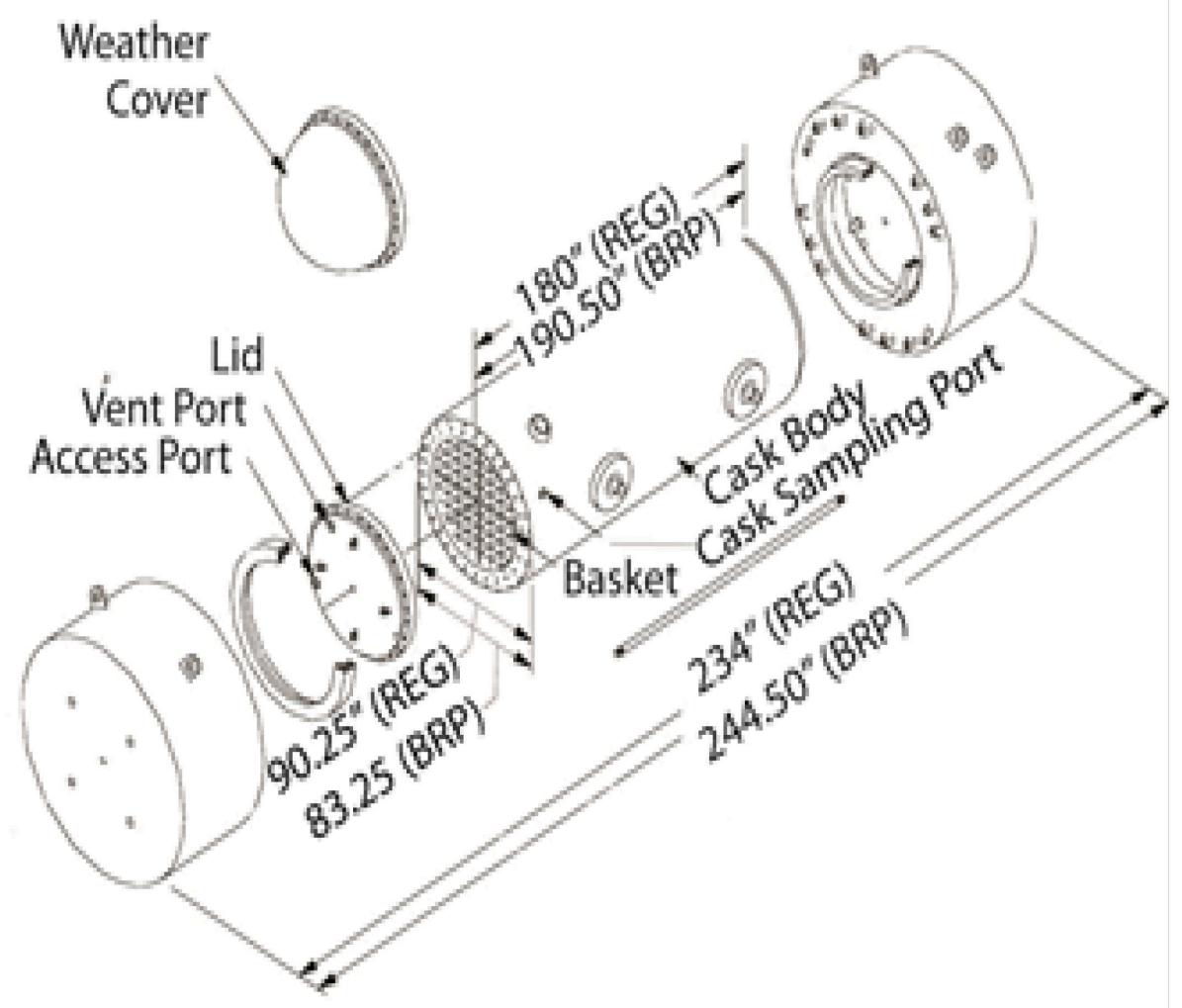

Figure 16. TN-REG and BRP Cask Schematic.

Due to the fuel condition and low decay heat, the prescribed vacuum drying procedure did not remove all of the water. At the end of the drying procedure, the internal pressure of the casks rebounded from 3 torr (4 mbar) to 25-40 mbar (19-30 torr) over 65-135 hours. This pressure rise can be attributed to vaporization of water trapped inside failed cladding, or from liberation of water chemically or physically bound in crud or other oxides and hydroxides present in the fuel. Although this degree of pressurization did not challenge the pressure limits of the casks, a concern remained that the hydrogen gas produced by corrosion or radiolysis reactions of the residual water could reach concentrations in excess of the NRC limits.

Calculation of the radiolytic yield of hydrogen is only well established for liquid water so potential release from bound water could not be predicted adequately. Therefore, it was mandated that the cask cover gases be sampled and analyzed regularly to assure that the hydrogen concentration did not exceed established limits.

Prior to shipping the casks, calculations were done to predict the potential retained water. Simple dewatering of the BRP and REG casks would leave 22.3 and 13.3 liters of water, respectively, with the dominant water content present as chemically bound water in the iron hydroxide crud. Vacuum drying would reduce the physically sorbed water to 2.5 and 0.6 liters. The maximum design pressure for the TN casks is $45 \mathrm{psig}$ ( $4 \mathrm{~atm})$. When backfilled with 1 atmosphere, maximum normal operating pressures were 7.9 psig [1.5 atm] (BRP) and 6 psig [1.4 atm] (REG) for the net void volumes of 4980 and 5990 liters. Following drying to 3 torr it is calculated that less than 1 mole of water would remain, barring any 
physical or chemical interferences that would retard evaporation. The volume of retained water that would challenge the pressure limits would be 4 to 6 liters. (Ebner, EDF-2604, 2001).

Table 10. Calculated Value for Liters of Retained Water for West Valley Stored Spent Nuclear Fuel (EDF-2604).

\begin{tabular}{|c|c|c|}
\hline \multirow[b]{3}{*}{$\mathrm{H}_{2} \mathrm{O}$ State } & \multicolumn{2}{|c|}{ Amount of Retained Water, kg (1) } \\
\hline & BRP & REG \\
\hline & 351 failed rods (2) & 91 failed rods (2) \\
\hline $\begin{array}{c}\text { Free water in } \\
\text { radial clad gap (3) }\end{array}$ & 3.54 & 0.88 \\
\hline $\begin{array}{l}\text { Physisorbed water } \\
\text { on crud (4) }\end{array}$ & 2.34 & 1.52 \\
\hline $\begin{array}{l}\text { Chemisorbed water in } \\
\text { crud as FeOOH (4) }\end{array}$ & 16.9 & 11.0 \\
\hline $\begin{array}{l}\text { Chemisorbed water } \\
\text { as } \mathrm{UO}_{2}(\mathrm{OH})_{2}\end{array}$ & 2.46 & 0.61 \\
\hline $\begin{array}{l}\text { Chemisorbed water as } \\
\mathrm{UO}_{2}(\mathrm{OH})_{2} \cdot \mathrm{H}_{2} \mathrm{O} \text { (5) }\end{array}$ & 3.09 & 0.77 \\
\hline $\begin{array}{l}\text { Total potential residual } \\
\text { water after draining (6) }\end{array}$ & 22.33 & 13.29 \\
\hline
\end{tabular}

$1.1 \mathrm{~kg}=1$ liter

2. Estimates from ref 4.

3. Includes only the gap volume in which water may be retained by capillary force; does not include plenum volumes or porosity of the fuel rods.

4. Pertains to the external surfaces of all fuel rods.

5. Assumes corrosion product has completely filled the clad gap volume, but bas not distorted or ruptured the cladding. 6. Assumes the primary corrosion product is $\mathrm{UO}_{2}\left(\mathrm{OH}_{2} \cdot \mathrm{H}_{2} \mathrm{O}\right.$, not $\mathrm{UO}_{2}(\mathrm{OH})_{2}$. For conservatiam, also assumes that clad gap contains fully-dense corrosion product but no free water.

After receipt of the West Valley casks at Idaho, a series of evacuations and backfills were performed to reduce the residual water. Four backfills were performed between 2002 and 2003 to achieve an acceptable cask atmosphere.

Table 11. Summary of the annual $\mathrm{H}_{2}$ generation rates in the TN-REG and TN-BRP cask cover gases.

\begin{tabular}{|l|c|c|}
\hline \multirow{2}{*}{ Gas Sampling Date } & \multicolumn{2}{c|}{$\mathrm{H}_{2}$ Generation Rate, mol\%/yr } \\
\cline { 2 - 3 } & TN-REG & TN-BRP \\
\hline June 2002 & 2.0 & 1.4 \\
\hline May-June 2003 & 0.48 & 0.30 \\
\hline $\begin{array}{l}\text { September 2003(Annualized rate for the period following } \\
\text { cycle 4, performed in July 2003) }\end{array}$ & 0.27 & 0.08 \\
\hline
\end{tabular}




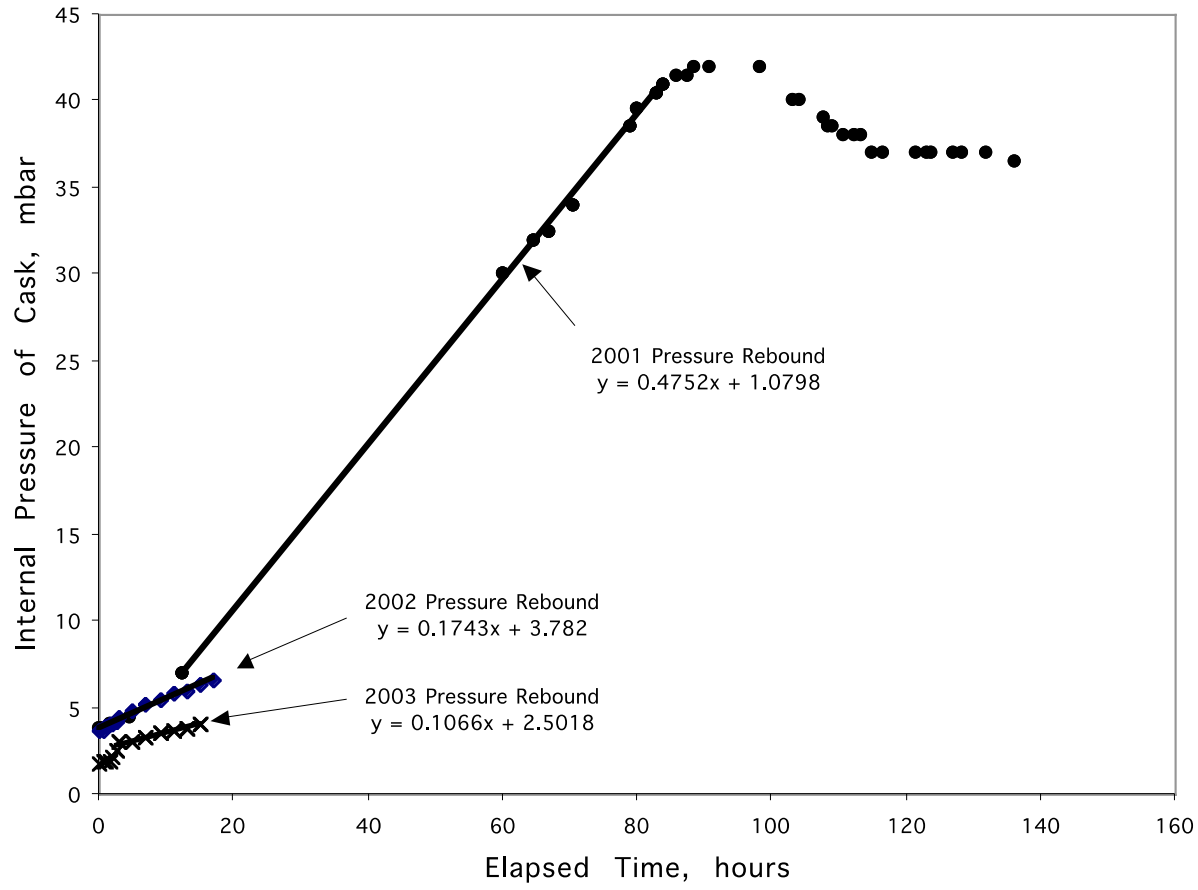

Figure 17. Pressure rebound in TN-REG cask after evacuation.

The figure shows the pressure rebound curve after the initial drying of the cask (cycle 1, top curve), after the June 2002 evacuation (cycle 2, middle curve), and after the June 2003 evacuation (cycle 4, bottom curve).

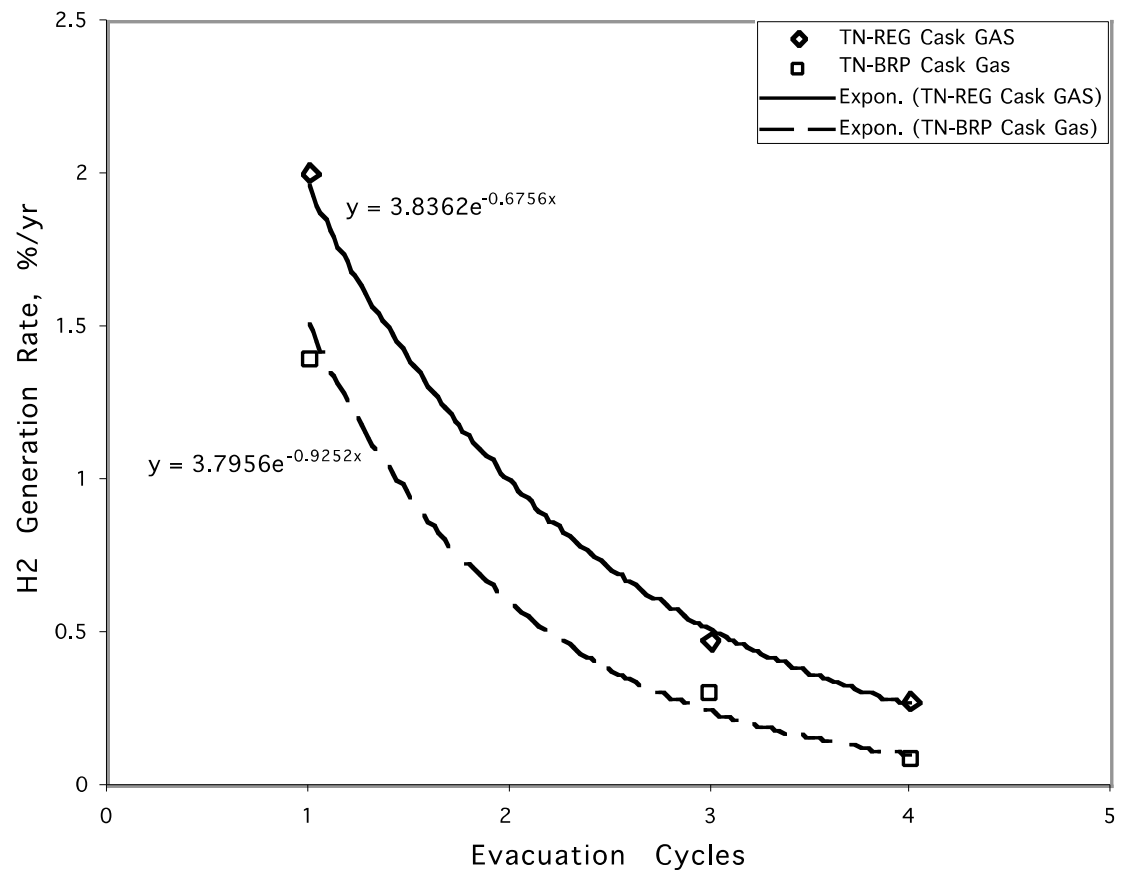

Figure 18. Annual hydrogen generation rates (mol\%/yr) as a function of the number of cask evacuation and backfill cycles. 
The evacuation/backfill/sampling cycles are numbered starting with the initial cask draining and drying (cycle 1) and increase successively with each cask evacuation, backfill, and gas sampling cycle

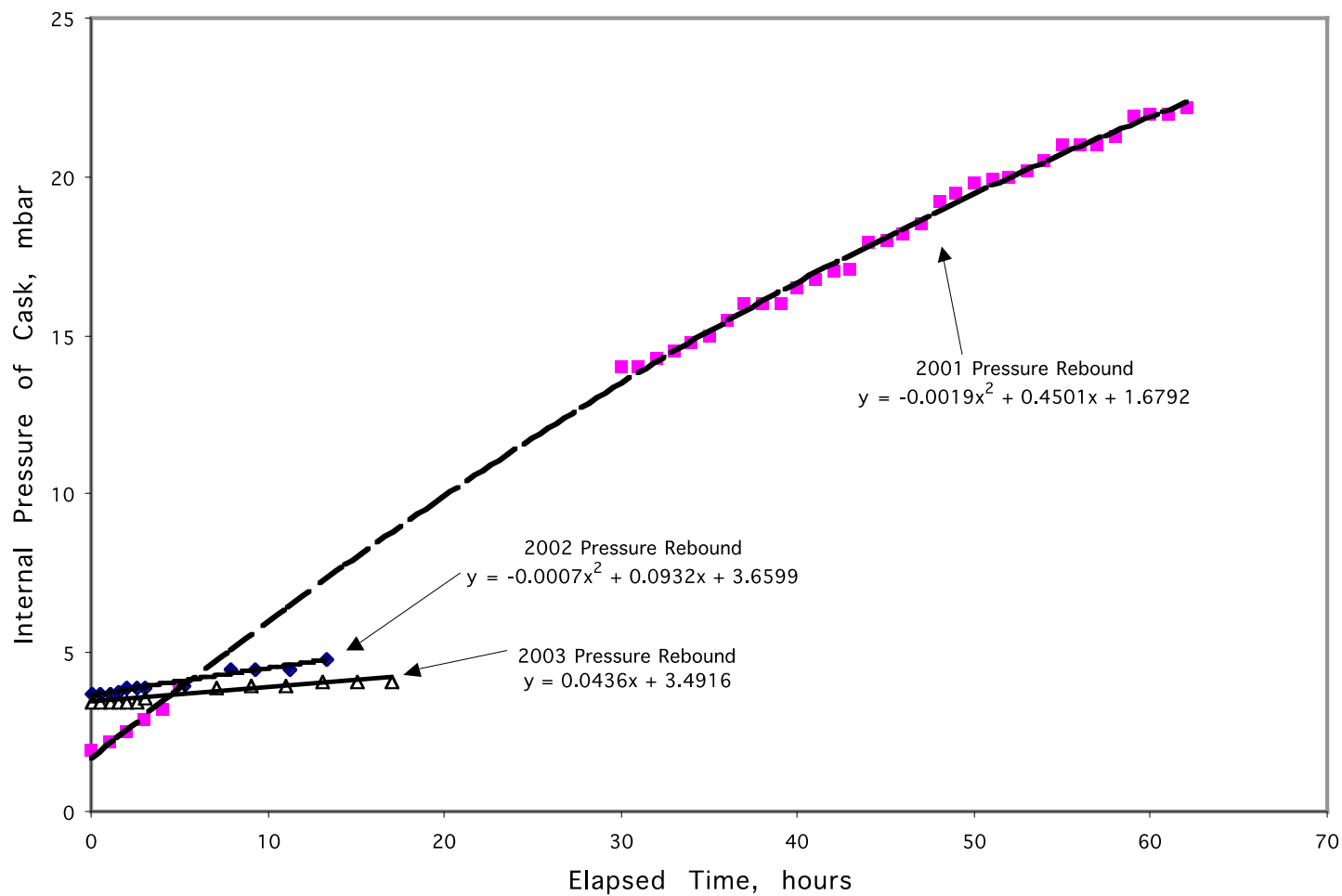

Figure 19. Pressure rebound in TN-BRP cask after evacuation.

The figure shows the pressure rebound curve after the initial drying of the cask (cycle 1, top curve), after the June 2002 evacuation (cycle 2, middle curve), and after the June 2003 evacuation (cycle 4, bottom curve). The low slopes of the two bottom rebound curves suggest vaporization of physisorbed and chemisorbed water.

Sampling of the West Valley Casks was performed in 2009, with TN-REG hydrogen concentration reaching 0.38 vol $\%$ and the TN-BRP only 0.02 vol $\%$.

Table 12. TN-REG and BRP Headspace Gas Concentrations EDF-9069.

\begin{tabular}{|c|c|c|c|c|c|c|c|}
\hline Cask & Date & $\begin{array}{c}\text { Pressure } \\
\text { (psig) }\end{array}$ & $\mathrm{H} 2$ vol\% & $\mathrm{N} 2$ vol\% & O2 vol\% & Ar vol\% & CO2 vol\% \\
\hline TN-REG & $6 / 5 / 03$ & - & 0.4 & 99.42 & 0.08 & 0.05 & 0.04 \\
\hline TN-REG & $6 / 5 / 03$ & - & $\begin{array}{c}\text { Nitrogen } \\
\text { Backfill }\end{array}$ & - & - & - & - \\
\hline TN-REG & $9 / 13 / 03$ & 1.56 & 0.07 & 99.83 & 0.03 & 0.06 & 0.01 \\
\hline TN-REG & $10 / 23 / 09$ & 1.51 & 0.38 & 99.62 & 0 & ND & 0 \\
\hline \hline TN-BRP & $5 / 28 / 03$ & - & 0.26 & 98.86 & 0.08 & 0.05 & 0.04 \\
\hline TN-BRP & $5 / 28 / 03$ & - & $\begin{array}{c}\text { Nitrogen } \\
\text { Backfill }\end{array}$ & - & - & - & - \\
\hline TN-BRP & $9 / 11 / 03$ & 1.69 & 0.02 & 99.88 & 0.03 & 0.06 & 0.01 \\
\hline TN-BRP & $10 / 17 / 09$ & 1.34 & 0 & 100 & 0 & ND & 0 \\
\hline
\end{tabular}




\subsection{Dummy PWR Fuel Assembly}

The Dry Rod Consolidation Project and the Prototypical Rod Consolidation Project were instrumental in demonstrating that individual fuel rods could be removed from assemblies and put into a condensedsize 2-piece canister that takes up only as much space as a single assembly. This approach was pursued quite aggressively and at least 40 assemblies were consolidated by the test projects. The dummy Westinghouse $15 \times 15$ PWR assembly that has been retained following the completion of those projects was fabricated by Westinghouse under contract to EG\&G Idaho, who was the INEL operating contractor at the time. After considerable discussion of the ways to fabricate a mockup assembly that would have the same weight and dimensions, it was concluded that the rods could be loaded with copper metal to achieve a density within $10 \%$ of that of $\mathrm{UO}_{2}$ pellets. The specifics of this assembly are well documented, indicating that the cladding is Zircaloy-4 as required, and the nominal weight is approximately $1500 \mathrm{lbs}$, as required. This particular example does not show signs of having been disassembled and reassembled. The unit has been $\mathrm{x}$-rayed, but negligible detail was detected, meaning that there is no visible division between pellets as would be seen for the $\mathrm{UO}_{2}$. A photograph of the assembly as it is at present is shown as Figure 20. 


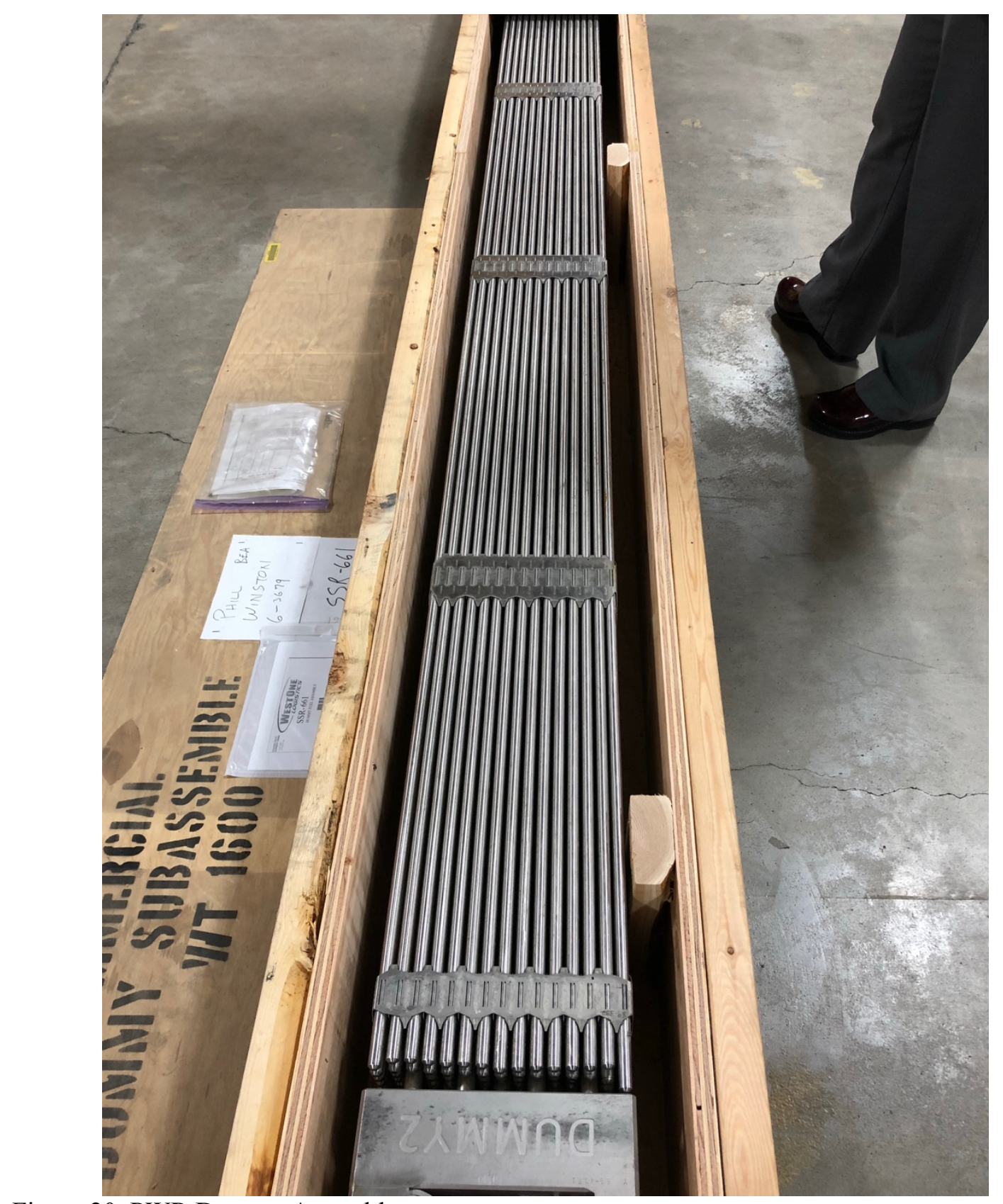

Figure 20. PWR Dummy Assembly 


\section{REFERENCES}

1. Carboneau, Michael L., EDF-1787, Source Term and Decay Heat Analysis for the LOFT and Commercial Reactor Fuel Stored in the TAN-607 Storage Pool, January 2001.

2. Dagbjartsson, Sig J., Beverly A. Murdock, Dennis E. Owen, and Philip E. MacDonald, EG\&G Idaho, Axial Gas Flow in Irradiated PWR Fuel Rods, TREE-NUREG-1158, September 1977.

3. Tolman, David D. Richard C. Williams, PE Bret Payne, Jack D. Tolman Ricky A. Gavalya, PE Analysis of CPP-603 for Opening Large Dry-Storage, Used Nuclear Fuel Casks, Task 3 Report, April 2015.

4. Moody, S.J., EDF-2922, Drying Requirements and Process for the REA-2023 Cask, March 2002.

5. Christensen, Allan B. EDF-2560 Assessment of REA-2023 Cask Vacuum Drying from Run Parameters, October 2002.

6. Whedon, Samuel; EDF-9329 Gas Monitoring in CPP-2707 with Portable Instrumentation, August 2009.

7. FCRD-UFD-2013-000027, Viability of Existing INL Facilities for Dry Storage Cask Handling.

8. McCardell, R. M., Characteristics of Nuclear Materials Stored in the MTR Canal, INEEL/INT-98-00768, October 1998.

9. McCardell, R.M., The Characteristics of Commercial Nuclear Materials Stored in the TAN Pool, INEL-INT-98-00767, LMITCO, September 1998.

10. McKinnon, M.A.; A.L. Doherty, Spent Nuclear Fuel Integrity During Dry Storage-Performance Tests and Demonstrations, PNNL-11576, June 1997

11. Mizia, R.E, and McCardell, R.M., EDF-1752 Evaluation of West Valley BWR and PWR Fuel Assembly and Fuel Rod Integrity, October 2001.

12. PLN-1720 Fuel Storage Cask Monitoring Plan

13. Reeder, D.L. and V.T. Berta, Loss of Fluid Test Facility, EG\&G Idaho, 1979.

14. SAR-112, Safety Analysis Report for the Outdoor Fuel Storage Facility

15. Vinjamuri, Krishna, Edgar M. Feldman, Carlan K. Mullen, Bret L. Griebenow, Alvin E. Arave, Robert C. Hill, Dry Rod Consolidation Technology Project at the Idaho National Engineering Laboratory, EGG-WM-8059, April 1988.

16. Wahnschaffe, Steven, Feasibility Of Using The Irradiated Fuel Storage Facility (IFSF) To Remove Commercial Used Fuel From The REA-2023 Cask, TEV-1187, March 2011. 


\section{Appendix A}

\section{Cost Estimate for Recovery of Cask and Opening in FHC (Fluor Idaho)}




\title{
Appendix A
}

\section{Cost Estimate Fluor Recovery of Cask and Opening in FHC}

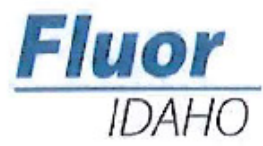

April 13, 2017

CCN 320645

\author{
Ms. Jennifer K. Cate \\ DOE-ID Contracting Officer \\ U.S. Department of Energy \\ Idaho Operations Office (DOE-ID) \\ 1955 Fremont Avenue \\ Idaho Falls, ID 83415-1221
}

$\begin{array}{ll}\text { SUBJECT: } & \text { Contract No. DE-EM0004083 - Funding Determination and Cost and Schedule } \\ \text { Estimate for Fuel Retrieval }\end{array}$

REFERENCES: (a) Jennifer K. Cate Letter to Thomas. M. Williams, Contract No. DE-EM0004083 Request for CLIN-3 Cost and Schedule Estimate and Funding Determination for Fuel Retrieval (AS-CMD-ICP/Fluor-17-048), February 6, 2017, CCN 320332

(b) Thomas M. Williams Letter to Jennifer K. Cate, Contract No. DE-EM0004083 Schedule Estimate and Funding Determination for Fuel Retrieval from the Castor V/21 Cask, March 15, 2017, CCN 320512, Closes Action

(c) Aaron S. Nebeker email to Thomas M. Williams, Extension Granted, April 4, 2017, CCN 320644

Dear Ms. Cate:

In reference (a) above, DOE-ID requested Fluor Idaho, LLC (Fluor Idaho) to provide a funding determination and corresponding cost and schedule estimate to retrieve a Westinghouse fuel assembly for the Joint Fuel Cycle Studies Program (JFCS). In reference (b) above, Fluor Idaho requested an extension for the delivery of the funding determination and estimate. In reference (c) above, DOE-ID granted the due date extension to April 13, 2017. Enclosed, in response to references (a) and (c) above, Fluor Idaho submits a funding determination and cost and schedule estimate for the preparations and operations to retrieve a Westinghouse fuel assembly for the JFCS.

This estimate and proposed schedule are based on several significant assumptions (other assumptions are noted on pages 6 and 7 of the Cost Estimate Support Data Recapitulation):

- Receipt of direction to commence preparation activities with funding by May 16, 2017. The schedulo may be improved by an earlier response.

- The CPP-603 Large Cask Adaptation Prcject will perform the scope to fill in the CPP-603 west truck ramp and will provide an operational cask hancling crane in CPP-603 by January 4, 2018.

- The NAC-LWT cask will be available per the schedule to support the shipment of the fuel assembly from CPP-603 to the Materials and Fuels Complex (MFC).

- All aspects of this new work scope impact ICP Core target scope schedules. This impact will be addressed in a Spent Nuclear Fuel (SNF) program replan that is in part pending the decision to include this new work.

- A funding determination accompanies this cost estimate that identifies some of the scope as Capital Equipment based on guidance received from DOE-ID. This scope is directly tied to providing the capability to handle the Castor V/21 cask and fuel assembly and is not directly tied

'FRESH SOLUTONS TO SAFLY OSNSOLIDATR, ACULLRATZ AND DILVER. THE TDAHO CLEANUP PROTCT" t580 Samelio Strcet ldgho Falls, Itesho 83402 | www.fluor-idgho.com 
Ms. Jennifer K. Cate

April 13, 2017

CCN 320645

Page 2

to the cask handling crane upgrade provided by the CPP-603 Large Cask Adaptation Project. However, the handling of the Castor V/21 cask in CPP-603 is directly dependent on the crane upgrade. The schedule assumes that DOE-ID will agree that performing those two projects sequentially will not imply segregation of a capital project.

This estimate can be placed into context by comparison to the recent commencement of ATR wet to dry SNF transfers. The actual burdened costs for the stariup and first month of operations of ATR wet to dry transfers during FY16 and FY17 have been $\$ 4.2 \mathrm{M}$. Preparations took 8 months to receive authorization to commence operations. This startup required a DOE readiness assessment, procedure revisions, and some equipment modifications, procurement, and fabrication similar to the scope of this estimate. The ATR startup required only minimal safety basis revisions (no SAR/TSR revisions) and no subcontracts, and was therefore about $\$ 0.9 \mathrm{M}$ less and 4 months shorter in duration than this estimate.

If you have technical questions, please contact Dale Luke at (208) 520-2187. For contractual questions, please call me at (208) 533-0537, or email at thomas.williams@icp.doe.gov.

Sincerely,

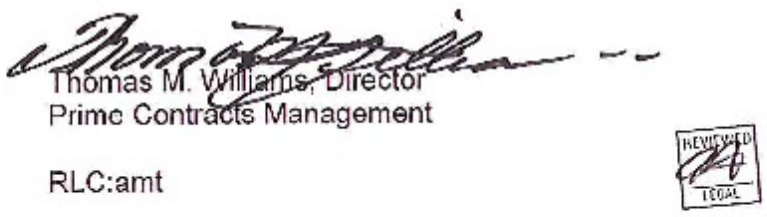

Attachment

CC: DOE-ID

M. Boline

M. B. Hinman

M. M. Mitchell-Williams

A. S. Nebeker

A. O. Perez

J. P. Zimmerman

DOE-ID Admin Support Center

DOE-ID Records Management

Fluor Idaho

P. Davis

F. P. Hughes Fat-

M. W. Manderbach

J. Saye

M. J. Swain 
Appendix B

\section{Cost Estimate Support Data Recapitulation}




\title{
Appendix B
}

\section{ICP Core Contract Pricing Proposal}

\author{
ICP Core Contract Pricing Proposal Cover Sheet \\ M-551 SNF Retrieval for Joint Studies Fuel Recycle Program \\ Contract No.: \\ DE-EM0004083 \\ Name and Address of Offeror: \\ Fluor Idaho, LLC \\ 1580 Sawtelle Street \\ Idaho Falls, ID 83402 \\ Name (Mail Stop) and Telephone Number \\ Thomas M. Williams (MS 9101) \\ of Point of Contact: \\ (208) 533-0537 \\ Contract Administration Office: \\ Ms. Jennifer K. Cate \\ 1955 Fremont Avenue \\ Idaho Falls, ID 83415-1240 \\ (208) 526-0631 \\ Type of Contract Action: \\ B.5 Non-Target, CLIN 3, CPFF \\ Proposed Cost, and Profit or Fee: \\ Proposed Cost: $\$ 5,036,183$; Proposed Fee: \\ $\$ 254,731$; Proposed Price: $\$ 5,290,914$ \\ Required Use of GFP: \\ In accordance with the Contract \\ Cost Accounting Standards Board \\ Disclosure Statement: \\ Fluor Idaho, LLC is subject to CAS and submitted \\ its CASB Disclosure Statement on June 9, 2016 \\ (Rev. 0). \\ Fluor's Disclosure Statement has been \\ determined to be adequate. Fluor has not \\ received any notice that it is or may be in non- \\ compliance with its Disclosure Statement or CAS. \\ This proposal is consistent with Fluor disclosed \\ practices and applicable CAS \\ This proposal is consistent with Flucr's \\ established estimating and accounting principles \\ and procedures and FAR Part 31, Cost \\ Principles.
}

Submittal Date:

April 13, 2017

This oroposal reflects our estimate and/or actual costs as of this date and conforms to the instructions in FAR 15-403-5(b)(1) and Table 15-2. By submitting this proposal, we grant the Contracting Officer and authorized representative(s) the right to examine, at any time before award, those records, which include books, documents, accounting procedures and practices, and other data, regardless of type and form or whether such supporting information is specifically referenced or included in the proposal as the basis for pricing, that will permit an adequate evaluation of the proposed price.

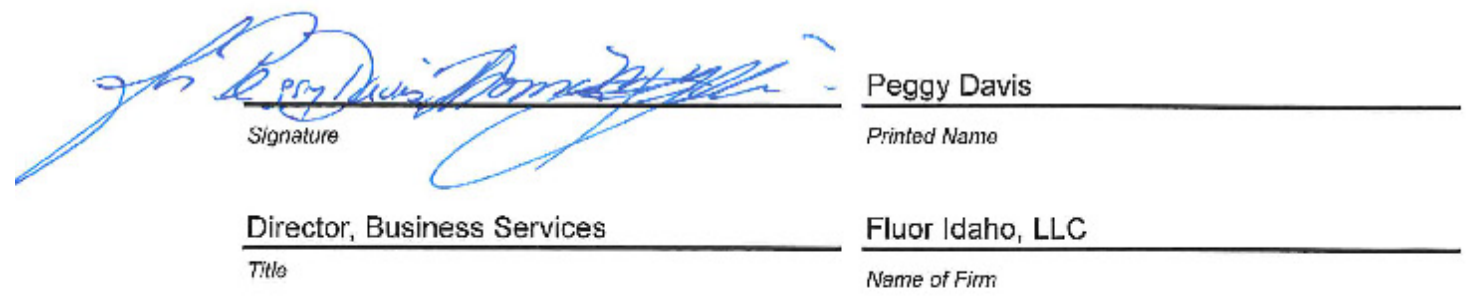


FLUOR IDAIIO

\section{COST ESTIMATE SUPPORT DATA RECAPITULATION}

Project Title: SNF Retrieval for Joint Studies Fuel Recycle Program

Listimator: Dale Luke

Date: $\quad \Lambda$ pril 13,2017

Estimate Type: B.5 Non-Target - Cost Estimate for FY 2017 - FY 2018

Filc: $\quad \mathrm{M}-551$

$\begin{array}{ll}\text { Approved By: RC Page } 1 \text { of } 8 & \end{array}$

I. PURPOSE: Brief description of the intent of how the estimate is to be used, i.e., for engineering study, comparative analysis, DWP, $L C B$ out-year planning, $B C P$, efc.

'This estimate is being prepared at the request of DOE-NE and will support preparations and operations to retricve a commercial spent nuclear luel (SNF) assembly out of the Castor V/21 cask located in the CPP-2707 storage facility at the Idaho Nuclear I'cchnical and Enginecring Conter (INTLC). The SNF assembly will be shipped to the Materials and Fuel Complex (MFC) to support the Joint Studies Fuel Recycle Program.

II. SCOPE OF WORK: Brief statement of the project's objective. Thorough overview and description of the proposed project. Identify work to be accomplished, as well as any specific work to be excluded.

The Castor V/21 dry storage cask is currently stored on the CPP-2707 pad at INTEC located at the Idaho National I aboratory (INI) Site.

DOF-ID is the landlord for the TNL and has contracted with Fluor Idaho for the Idaho Cleanup Project (ICP). The Fuel Retrieval for Joint Studics Fucl Rccycle Program is an ICP subproject and will be managed consistent with the requirements of DOE Order $413.3 \mathrm{~B}$, including environmental, nuclear and non-nuclear safety and health management.

DOE-ID is responsible for directing Fluor Idaho to implement the scope, including maintenance and opcrations, provision of designs, hardware, and documentation, and compliance with contractually applicable state and federal regulations and DOE Orders.

Performance of this activity will require extensive preparations including: equipment design and fabrication, safety analysis document revisions and implementation, procedure development, personnel training, establishment of a subcontract with a vendor to move the cask, road repair, installation of the IFSF transfer car insert, and rcadincss activitics.

\section{Operations Schedule}

The objective is to retrieve the SNF assembly from the Castor V/21 cask in the spring of 2018 as soon as weather conditions will allow operations in CPP-2707 and the gravel road will support the transport. The ability to meet this objective is dependent on factors outside the control of Fluor Idaho. Preparing for and executing this scope of work will impact the schedule for ICP core scope such as A'TR SNF wet to dry transfers and EBR II 


\begin{tabular}{|llc|}
\hline \multicolumn{2}{|c|}{ COST ESTMMATE SUPPORT DATA RECAPITULATION } \\
Project Title: & SNF Retrieval for Joint Studies Fuel Recycle Program & \\
File: & M-551 & Page 2 of 8 \\
\hline
\end{tabular}

SNF transfers both for operations and for activities to prepare for operations. The Fluor Idaho SNF schedule is subject to DOE-EM direction and priorities. In addition, the NAC-LWT cask rental availability will also drive the operations schedule.

The Castor V/21 cask will be moved to the CPP- 603 truck bay and place dinto the IFSF transfer car. It will be moved into the IFSF fuel-handling cave where a spent fuel assembly will be removed from the cask and temporarily stored in the cave. The Castor V/21 cask will be returned to the pad at CPP-2707. Then a NAC-LWT cask will be provided by the sponsor and will be placed in the IFSF fuel-handling cave where the spent fuel assembly will be loaded into the cask. The NAC-LWT will be prepared for shipment and the sponsor will retrieve the loaded cask and ship it to MFC.

$\underline{\text { Scope and Deliverables by Work Package }}$

Work included in this estimate has been broken down into the following five work packages:

\section{Work Package A.1.22.01.01 - Project Management:}

Specific scope of work to be performed:

A. Provide support for tracking of requirements, scope, cost, and schedule and close coordination with the sponsor at DOE-ID.

B. Maintain project risk management plans as needed.

C. Maintain a resource loaded, baseline schedule and cost for the transfer.

D. Provide monthly reporting on this project.

Deliverables specifically addressed in this estimate:

A. TNTEC Management and Support Programs

B. Project Management

C. One Baseline Change Proposal (BCP) to establish the baseline

\section{Work Package A.1.22.01.02 - Preparations for Operations:}

Scope of work to be performed in this Work Package:

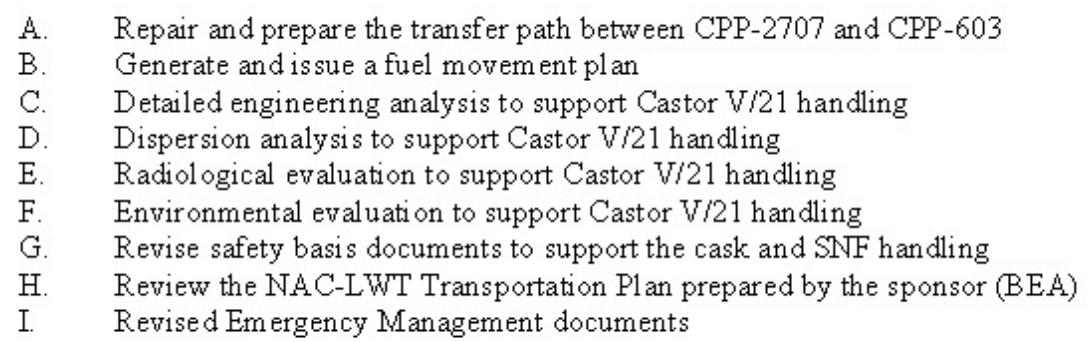




\begin{tabular}{|c|c|}
\hline $\begin{array}{l}\text { Project Title: } \\
\text { File: }\end{array}$ & $\begin{array}{l}\text { COST ESTMMATE SUPPORT DATA RECAPITULATION } \\
\text { - Continued - } \\
\text { SNF Retrieval for Joint Studies Fuel Recycle Program } \\
\text { M-551 }\end{array}$ \\
\hline $\begin{array}{l}\text { J. } \\
\mathrm{K} . \\
\mathrm{L} \\
\mathrm{M} \\
\mathrm{N} \\
\mathrm{O}\end{array}$ & $\begin{array}{l}\text { Provide operating procedures } \\
\text { Revise system design descriptions affected by new equipment } \\
\text { Develop and deliver training } \\
\text { Implement safety basis changes } \\
\text { Prepare for and conduct a Contractor Readiness Assessment } \\
\text { Prepare for and support a DOE Readiness Assessment }\end{array}$ \\
\hline $\begin{array}{l}\mathrm{G} . \\
\mathrm{H} . \\
\mathrm{I} . \\
\mathrm{J} . \\
\mathrm{K} . \\
\mathrm{L} . \\
\mathrm{M} . \\
\mathrm{N} . \\
\mathrm{O} . \\
\mathrm{P} . \\
\mathrm{Q} . \\
\mathrm{R} . \\
\mathrm{S} .\end{array}$ & $\begin{array}{l}\text { ic deliverables for this work package: } \\
\text { Fuel movement plan } \\
\text { Castor V/21 handling EDF } \\
\text { Dispersion analysis EDF } \\
\text { ALARA evaluation and RWP } \\
\text { Environmental Checklist } \\
\text { Criticality safety evaluation for Castor V/21 handling and PWR fuel handling in } \\
\text { IFSF cave } \\
\text { SAR/TSR-114 revision } \\
\text { SAR/TSR-112 revision } \\
\text { CPP-603 safety basis list revisions (LST-331, LST-332, LST-363) } \\
\text { CPP-2707 safety basis list revisions (LST-339, LST-340, LST-372) } \\
\text { NAC-LWT Transportation Plan Review (review only) } \\
\text { Revised Emergency Management documentation } \\
3 \text { new Technical Procedures (TPRs) } \\
1 \text { revised Technical Procedure (TPR) } \\
\text { SDD-44, SDD-54, SDD-111 updated for new equipment } \\
\text { Operations training developed and delivered } \\
\text { Safety basis document changes implemented } \\
\text { Contractor Readiness Assessment completed and declaration of readiness } \\
\text { DOE Readiness Assessment completed and authorization to commence operations }\end{array}$ \\
\hline $\begin{array}{l}\text { Exc. } \\
\text { A. } \\
\text { B. }\end{array}$ & $\begin{array}{l}\text { Excludes work performed by the cask movement subcontractor, which is in } \\
\text { another work package. } \\
\text { Excludes preparation of a transportation plan for the NAC-LWT shipment from } \\
\text { CPP- } 603 \text { to MFC. This will be provided by the sponsor. }\end{array}$ \\
\hline
\end{tabular}

\section{Work Package A.1.22.01.03-Operations:}

Scope of work to be performed in this Work Package:

A. Perform operations dry run training and facility preparations to prepare for the readiness activities

B. Remove and install Castor V/21 monitoring equipment

C. Support subcontractor movement of Castor V/21 cask to and from CPP-603

D. Perform operations to handle the Castor V/21 cask in CPP-603 and retrieve the fuel assembly 


\begin{tabular}{|c|c|}
\hline $\begin{array}{l}\text { Project Title: } \\
\text { File: }\end{array}$ & $\begin{array}{l}\text { COST ESTMMATE SUPPORT DATA RECAPITULATION } \\
\text { - Continued - } \\
\text { SNF Retrieval for Joint Studies Fuel Recycle Program } \\
\text { M-551 }\end{array}$ \\
\hline E. & $\begin{array}{l}\text { Perform operations to handle the NAC-LWT cask and load the fuel assembly into } \\
\text { the cask }\end{array}$ \\
\hline F. & Partially disassemble and restore the PCS to support Castor V/21 cask handling \\
\hline $\begin{array}{l}\text { Specif } \\
\text { A. } \\
\text { B. } \\
\text { C. } \\
\text { D. } \\
\text { E. } \\
\text { F. } \\
\text { G. }\end{array}$ & $\begin{array}{l}\text { ic deliverables for this work package: } \\
\text { Trained fuel handing crew } \\
\text { Castor V/21 cask moved into the IFSF cave } \\
\text { Fuel assembly removed from the Castor V/21 } \\
\text { Castor V/21 cask returned to CPP- } 2707 \\
\text { NAC-LWT moved into the IFSF cave } \\
\text { Fuel assembly loaded into the NAC-LWT } \\
\text { NAC-LWT ready for transport to MFC }\end{array}$ \\
\hline \multicolumn{2}{|c|}{ Exclusions: } \\
\hline A. & $\begin{array}{l}\text { Excludes work performed by the subcontractor, which is in another work } \\
\text { package. }\end{array}$ \\
\hline B. & Excludes transport of the NAC-LWT to and from CPP- 603 (provided by sponsor) \\
\hline C. & $\begin{array}{l}\text { Excludes inspection of the Castor } V / 21 \text { contents other than minimal visual } \\
\text { inspection of the assembly removed from the cask to ensure it is intact for } \\
\text { shipment. }\end{array}$ \\
\hline D. & Excludes leak test of the NAC-LWT prior to shipment. \\
\hline E. & Excludes return of the SNF ass embly to INTEC. \\
\hline $\mathrm{F}$. & $\begin{array}{l}\text { Some budget for anticipated saf eguards and security support that will be charged } \\
\text { to this project has been included in this estimate based upon current requirements; } \\
\text { however, requirements are currently changing and increases in this cost due to } \\
\text { new/modified requirements is excluded. }\end{array}$ \\
\hline
\end{tabular}

\section{Work Package A.1.22.01.04-Capital Equipment:}

Scope of work to be performed in this Work Package:

A. Prepare for and install the IFSF transfer car adapter

B. Design, procure, fabricate and turnover to operations all equipment necessary to perform the activity

Specific deliverables for this work package:

A. Work order to install the IFSF transfer car adapter

B. Installation of the IFSF transfer car adapter

C. IFSF transfer car adapter acceptance and operations turnover

D. Reinstallation of the PCS

E. Design, procurement/fabrication, and operations turnover for the following anticipated equipment

1. Temporary cask lid assembly (provides shiel ding)

2. Castor W/21 cask flange protector

3. Cask bolt rack 


\begin{tabular}{|llc|}
\hline \multicolumn{2}{|c|}{ COST ESTMMATE SUPPORT DATA RECAPITULATION } \\
Project Title: & SNF Retrieval for Joint Studies Fuel Recycle Program & \\
File: & M-551 & Page 5 of 8 \\
\hline
\end{tabular}

4. Cask lid stand (supports lid seal replacement)

5. Cask lid lifting equipment (supports remote handling in IFSF cave)

6. Remote cask flange cleaning brush

7. Swivel Hoist Ring holder

8. PWR fuel assembly grapple (supports remote handling in IFSF cave)

9. Trunnion clips and rigging to handle Castor V/21

10. IFSF transfer car seismic adapter for Castor V/21 (pedestal and ring)

11. Transfer car adapter lift device (to support installation)

12. Hydraulic torque wrench and pump

13. Rigging

Exclusions:

A. Excludes design and fabrication of an insert or basket for the NAC-LWT cask to support transport of the PWR as sembly (provided by sponsor).

\section{Work Package A.1.22.01.05 - Cask Movem ent Subcontract:}

Specific scope of work to be performed:

A. Subcontractor provide crane and transport to move the Castor V/21 from CPP2707 to CPP-603 and back to CPP-2707

B. Subcontractor support for training, dry runs, and readiness assessments

C. Subcontractor mobilize equipment

D. Subcontractor move the Castor V/21 cask

E. Subcontractor demobilize equipment

Deliverables specifically addressed in this estimate:

A. Castor V/21 cask moved from CPP-2707 to CPP-603 and back

III. BASIS OF THE ESTIMATE: Overall methodology and rationale of how the estimate was developed. Source documents to include drawings, design reports, engineers' notes and/or other documentation upon which the estimate is originated. Overall explanation of sources for resource pricing.

The basis of estimate for each activity is documented in the Detailed Cost Estimating Spreadsheet. In general, the scope is based on a conceptual design report RPT-1380 prepared in 2015 under the direction of DOE. Experience with the West Valley cask relocation in 2014 was applied as well as experience with many other spent nuclear fuel handling activities performed at INTEC over the last 10 years and more. The actual costs for the startup and first month of operations of ATR wet to dry transfers during FY 16 and FY17 (\$4.2M) were also used as a general check since this startup required a DOE readiness assessment and some equipment modifications, procurement, and fabrication.

The ATR startup required only minimal safety basis revisions (no SAR/TSR revisions) and no subcontracts and so was about $\$ 1 \mathrm{M}$ less than this estimate. 


\begin{tabular}{|llc|}
\hline \multicolumn{2}{|c|}{ COST ESTMMATE SUPPORT DATA RECAPTULATION } \\
Project Title: SNF Retrieval for Joint Studies Fuel Recycle Program & \\
File: & M-551 & Page 6 of 8 \\
\hline
\end{tabular}

IV. ASSUMPTIONS: Condition statements accepted or supposed true without proof of demonstration; statements adding clarification to scope. An assumption has a direct impact on total estimated cost.

A. The CPP-603 Large Cask Adaptation Project will provide an operational tandem crane in CPP-603 capable of lifting the Castor V/21 cask on or before January 4 , 2018. However, this project will not provide analysis and safety basis documentation to support use of the crane in tandem to handle a large cask.

B. The CPP-603 Large Cask Adaptation Project will design and fabricate the IFSF transfer car adapter, but will not install it or provide lifting equipment.

C. The CPP-603 Large Cask Adaptation Project will fill in the CPP-603 west truck ramp and install a concrete surface at floor level. This scope is currently contingent scope for the CPP-603 Large Cask A daptation Project and is not currently funded within that project.

D. The CPP-603 Large Cask Adaptation Project will disassemble the IFSF PCS for the crane load test and leave it down to facilitate the installation of the transfer car insert.

E. The sponsor will rent and provide transportation of the NAC-LWT cask to and from CPP-603 to support the agreed upon operations schedule.

F. The sponsor will provide an insert or basket for the NAC-LWT cask if needed to transport the PWR assembly.

G. A leak test of the NAC-LWT will not be required prior to shipment, or the sponsor will perform this activity.

H. The sponsor will provide the NAC-LWT transport plan that provides the safety basis for the cask transport.

I. The sponsor will provide direction concerning which spent fuel assembly in the Castor V/21 cask is to be retrieved.

J. Direction to commence preparations and funding will be received by Fluor Idaho about May 15, 2017. The start of operations in FY2018 may be accelerated by providing direction and funding to commence before this date.

K. Weather in March and April 2018 will allow dry runs to support a CRA and RA and allow commencement of operations first of May 2018.

L. Castor V/21 lid seal can be replaced by making an IFSF cave entry, vice removing the lidfrom the cave.

M. Existing equipment can be used to temporarily store the PWR assembly in the IFSF cave - such as an existing storage canister.

N. No other fuel handling activities will occur in the IFSF cave requiring reconfiguration of equipment and transfer car after the time in-cell activities commence until operational activities for this project are complete. If other activities are to be performed, those activities will perform all configuration changes needed to perform the activity and return back to the configuration needed for this project.

O. Dry runs will be performed prior to actual operations, but will not include actual use of the cask(s)

P. Sponsor will perform a drop analysis of the NAC-LNT cask, which will be used by Fluor Idaho for handling the PWR fuel assembly. 


\begin{tabular}{|llc|}
\hline \multicolumn{2}{|c|}{ COST ESTMMATE SUPPORT DATA RECAPITULATION } \\
Project Title: SNF Retrieval for Joint Studies Fuel Recycle Program \\
File: & M-551 & Page 7 of 8 \\
\hline
\end{tabular}

Q. The SNF assembly shipped to MFC will not be returned to INTEC for storage R. An allowance for BEA Safeguards and Security support has been included in this estimate based upon current requirements. Requirements will not change in a way that increases these costs.

V. MANAGEMENT RESERVE GUIDELINE IMPLEMENTATION: Explanation of methodology used in determining overall contingency. Identify any specific drivers or items of concern.

DOE has directed Fluor Idaho to not include Management Reserve in this estimate. Fluor Idaho has complied with that direction and has not applied management reserve to the Total Cost.

Specific items of risk are identified as follows:

A. Uncertainty in equipment availability

B. Schedule risk (Availability of the new tandem crane at CPP-603).

C. Operational issues and delays

D. Uncertainty of Castor V/21 cask and fuel condition.

\section{OTHER COMMENTS/CONCERNS SPECIFIC TO THE ESTIMATE:}

A. Preparing for and executing this scope of work will impact the schedule for ICP core scope such as ATR SNF wet to dry transfers and EBR II SNF transfers both for operations and for activities to prepare for operations. The Fluor Idaho SNF schedule is subject to DOE-EM direction and priorities.

B. Recently established average FY 2017 Fluor Idaho non-represented exempt and non-exempt personnel wage rates are utilized in the estimate. Human Resources provided a list of currently utilized General Labor Codes (GLC) and associated average FY 2016 base wage rates, by GLC, on August 12, 2016. Based on surveys from the Society for Human Resource Management and World at Work, Fluor anticipates a FY 2017 wage increase of $3.1 \%$. To establish FY 2017 wage rates, $50 \%$ of the anticipated increase was allocated over the entire fiscal year to reflect the mid-year wage rate increase. These rates are subject to change in the future.

C. The Fluor Idaho provisional fringe benefit rate established September 29, 2016 is $57.29 \%$ for FY 2017 - FY 2021. Fringe benefit rates are subject to change in the future.

D. Recently established average FY 2017 base wage rates for individual, signatory craft (United Steel Workers) personnel, if applicable, have been used in the estimate. Human Resources provided average FY 2016 base wage rates, by GLC, on August 12, 2016. The FY 2017 rates reflect an anticipated 3.0\% May 2017 rate increase in accordance with the Working Agreement between Fluor Idaho, LLC and the United Steel, Paper and Forestry, Rubber, Manufacturing, Energy, Allied Industrial and Services Workers International. The rate was prorated across the fiscal year. These rates are subject to change in the future. 


\begin{tabular}{|llc|}
\hline \multicolumn{2}{|c|}{ COST ESTMMATE SUPPORT DATA RECAPITULATION } \\
Project Title: & SNF Retrieval for Joint Studies Fuel Recycle Program & \\
File: & M-551 & Page 8 of 8 \\
\hline
\end{tabular}

E. Recently established average FY 2017 base wage rates for Force Account personnel, if applicable, have been used in the estimate. Hum an Resources provided average FY 2016 base wage rates, by GLC, on August 12, 2016. The FY 2017 rates reflect a $3.0 \%$ rate increase on June 1,2017 in accordance with the INL Site Stabilization Agreement. The rate was prorated across the fiscal year. These rates are subject to change in the future.

F. The Fluor Idaho provision al Program Overhead $(\mathrm{POH})$ rates established September 29,2016 are used in this estimate. The $\mathrm{POH}$ rates are $26.83 \%$ for FY $2017,27.57 \%$ for FY 2018, 28.9\% for FY 2019, 35.12\% for FY 2020. The FY $2021 \mathrm{POH}$ rate is the Contract Section H.22 Indirect Rate Ceiling rate of $45 \%$. This overhead adder has been applied to all labor and non-labor costs.

G. The Fluor Idaho provisional Defined Benefit Pension rates established September 29,2016 is $10.10 \%$ for FY 2017, $10.88 \%$ for FY 2018, 15.51\% for FY 2019 , $19.44 \%$ for FY 2020 and $28.52 \%$ for FY 2021. This pension adder has been applied to all labor and non-labor costs, including subcontracts. Pension rates are subject to change in the future.

H. The Fluor Idaho provisional General and Administrative (G\&A) rates established September 29,2016 are used in this estimate. The G\&A rates are $0.14 \%$ for $F Y$ $2017,0.15 \%$ for FY 2018, $0.22 \%$ for FY $2019,0.20 \%$ for FY 2020 . The FY 2021 G\&A rate is the Contract Section H.22 Indirect Rate Ceiling rate of $0.12 \%$. This home office allocation adder has been applied to all labor and non-labor costs, excluding pension.

I. An escalation rate of $2.8 \%$ for post FY 2017 work, if applicable, for non-represented exempt and non-exempt Fluor Idaho personnel base labor costs and for all non-labor costs has been used in the estimate.

J. An escalation rate of $3.0 \%$ for post FY 2017 work, if applicable, for United Steel Workers personnel base labor costs has been used in the estimate.

K. An escalation rate of $3.0 \%$ for post FY 2017 work, if applicable, for Force Account personnel base labor costs has been used in the estimate.

L. Idaho state sales tax (6\%), if applicable, has been included in the estimate.

M. All Fluor Idaho costs are to be fully recoverable.

N. Fee at $7.0 \%$ has been applied to all base costs.

O. The cost proposal was reviewed by Fluor Idaho senior management on April 11, 2017.

P. The direct cost (base labor hours and non-labor costs) will remain firm for 90 days. 


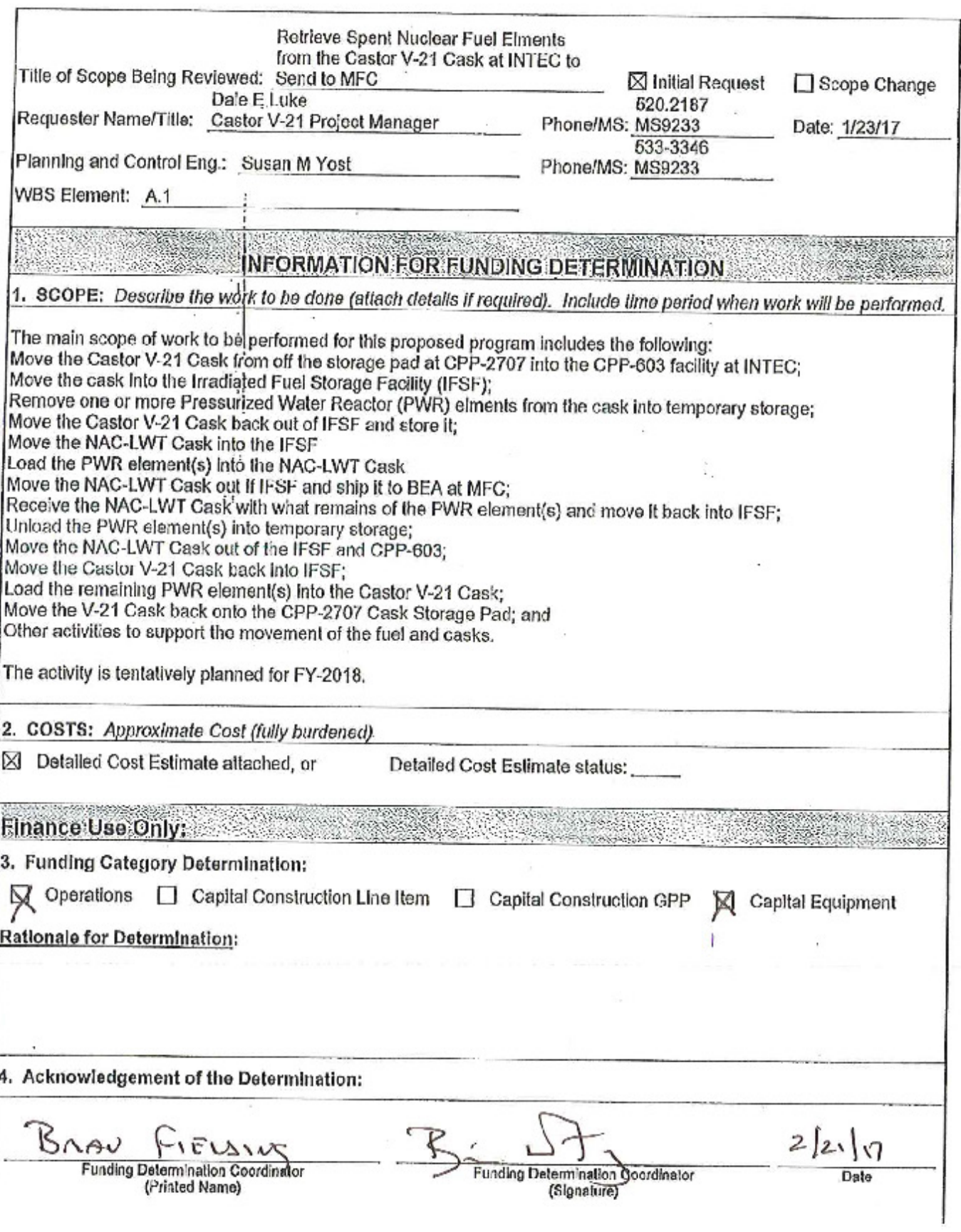




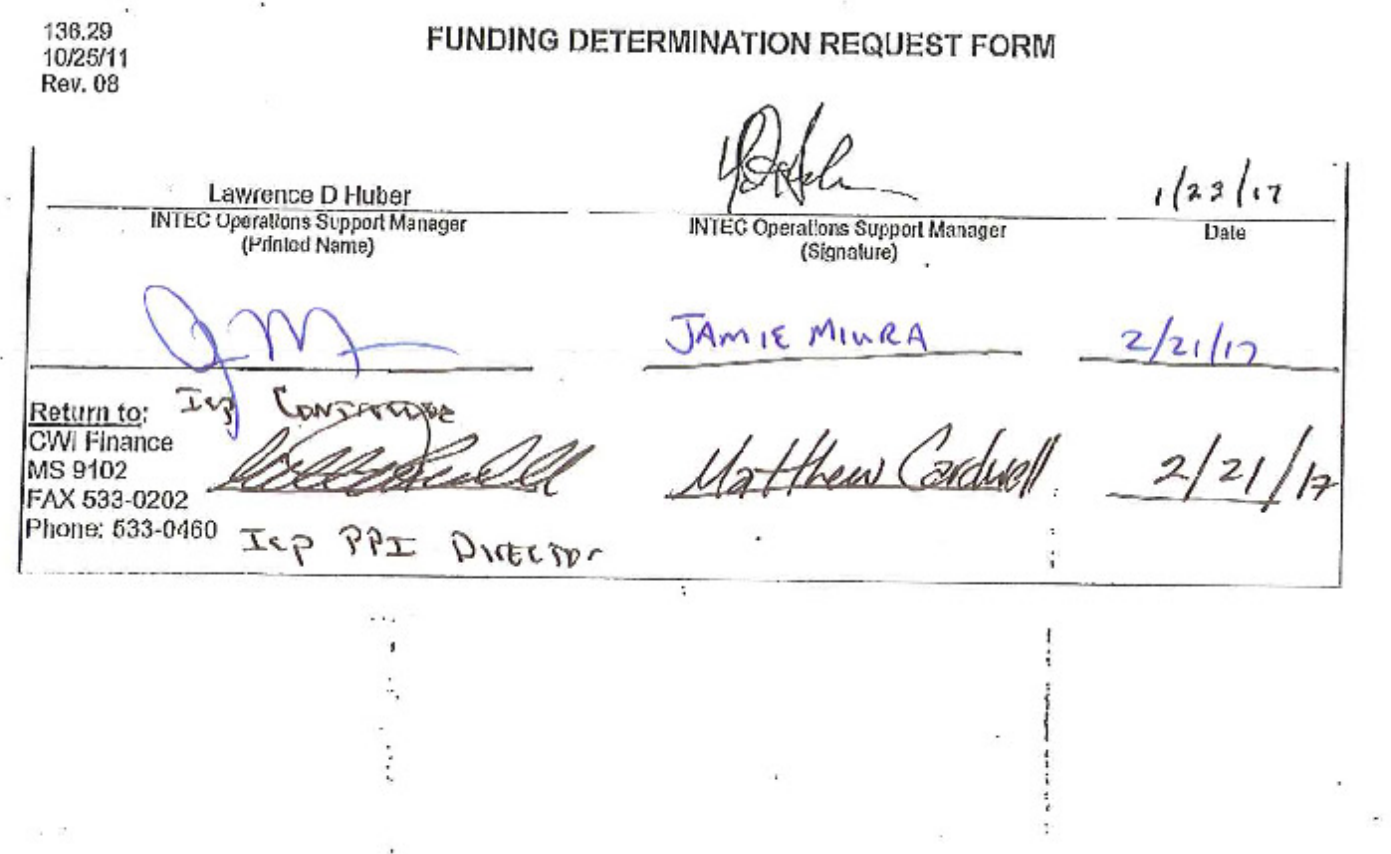




\section{Description}

Fluor Idaho Direct (Base) Labor Costs

Fluor Idaho Direct Materials and

Equipment Purchase and Lease Costs

(Excludes Sales Tax)

Fluor Idaho Other Direct Costs

Fluor Idaho Direct Subcontract and

Services Costs (Includes Lower Tiers and Staff Augmentation)

Fluor Idaho Direct Travel Costs

Total Fluor Idaho Direct costs

Fluor Idaho Escalation on Direct Costs

Fluor Idaho Fringe Benefit Costs on

Direct (Base) Fluor Idaho Labor Costs

and Associated Escalation ( $57.29 \%$ in

FY17 and Beyond)

Fluor Idaho Sales Tax on Direct Costs

and Escalation Where Applicable

Total Fluor Idaho Base costs Fluor Idaho Program Overhead Costs on Base Costs

Fluor Idaho G\&A Costs on Base Costs and Program Overhead Costs

Fluor Idaho Pension Costs on Base Costs

Total Fluor Idaho costs

Fluor Idaho Fee in accordance with Contract Section B (applied to Base casts ony)

FLUOR IDAHO TOTAL PRICE

INCREASE TO CONTRACT PERFORMANCE CEILING
Amount

Reference

$\$ 1,717,446$

FAR-15 Summary - All Years

$\$ 387,404$

FAR-15 Summary - All Years

FAR-15 Summary - All Years

$\$ 442,500$

FAR-15 Summary - All Years

$\$ 0$ FAR-15 Summary - All Years

$\mathbf{\$ 2 , 5 4 7 , 3 5 0} \quad$ FAR-15 Summary - All Years

$\$ 61,731$ FAR-15 Summary - All Years

$\$ 1,006,048 \quad$ FAR-15 Summary - All Years

$\$ 23,888$ FAR-15 Summary - All Years

$\$ \mathbf{3 , 6 3 9 , 0 1 7}$ FAR-15 Summary - All Years

$\$ 998,935 \quad$ FAR-15 Summary - All Years

$\$ 6,883$

$\$ 391,348 \quad$ FAR-15 Summary - All Years

$\$ \mathbf{5 , 0 3 6 , 1 8 3} \quad$ FAR-15 Summary - All Years

$7.00 \%$

$\$ 254,731$

FAR-15 Summary - All Years

$\$ 5,290,914$

$\$ 3,900,630$

Base Costs + G\&A + Fee 


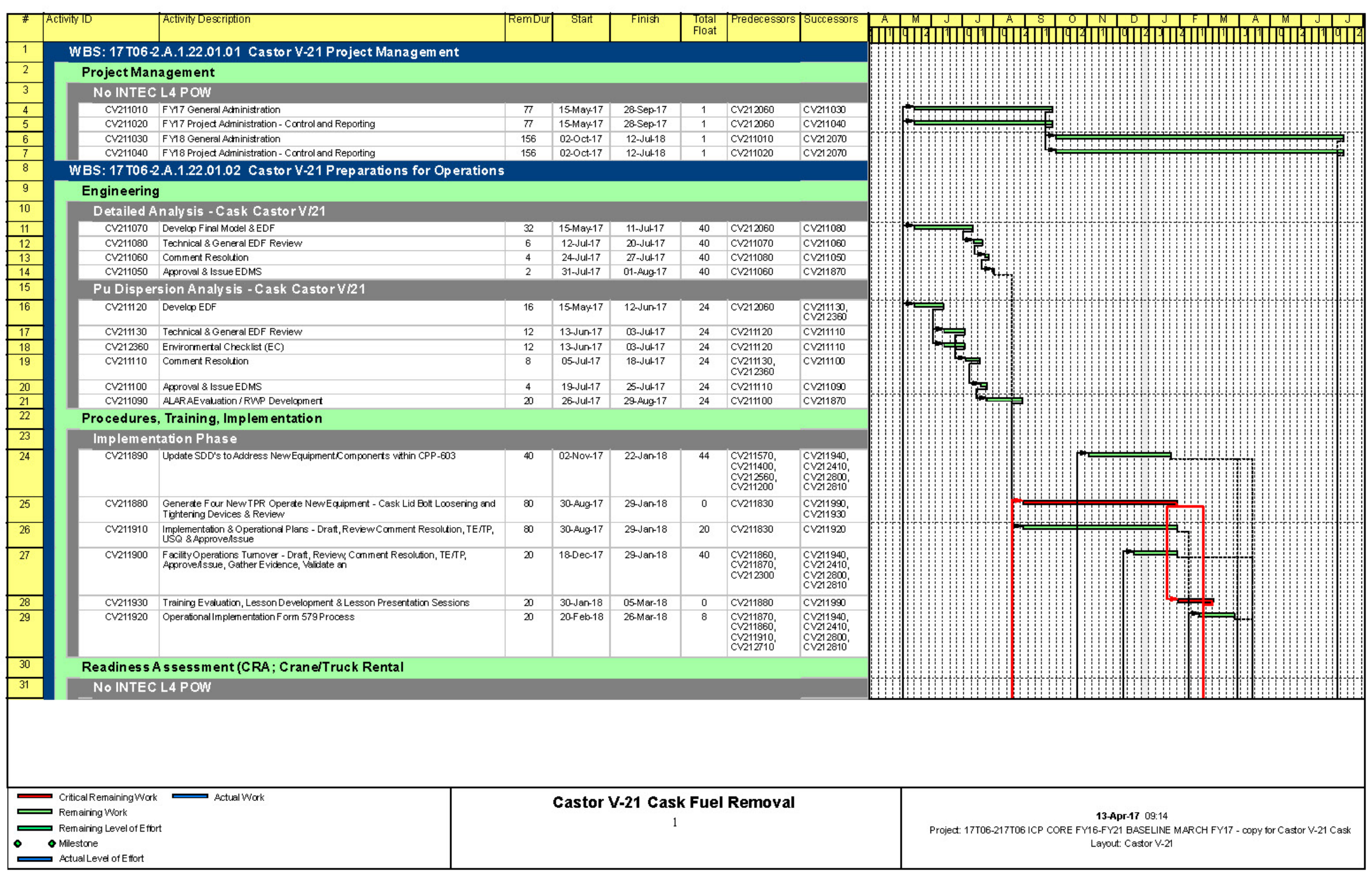




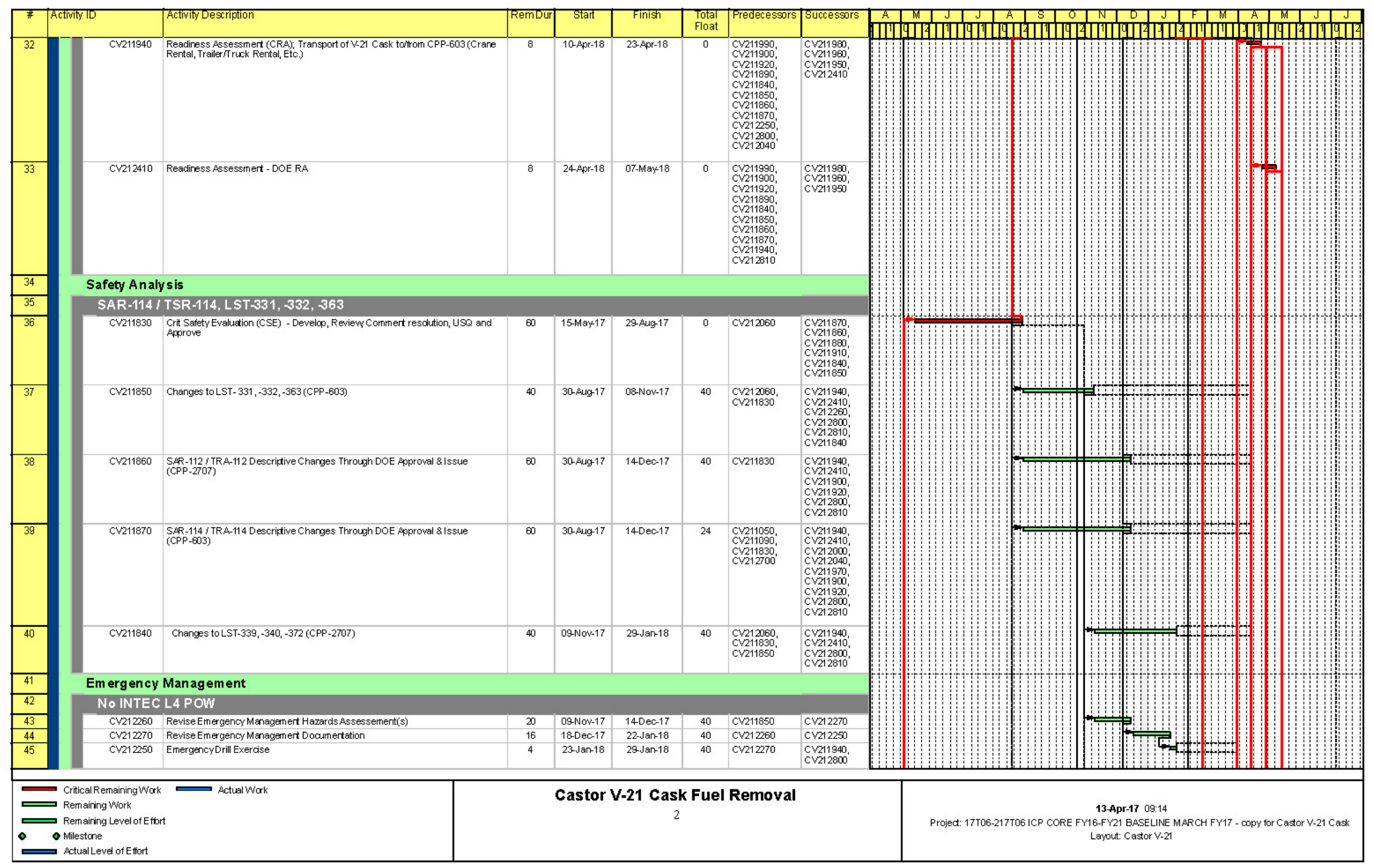




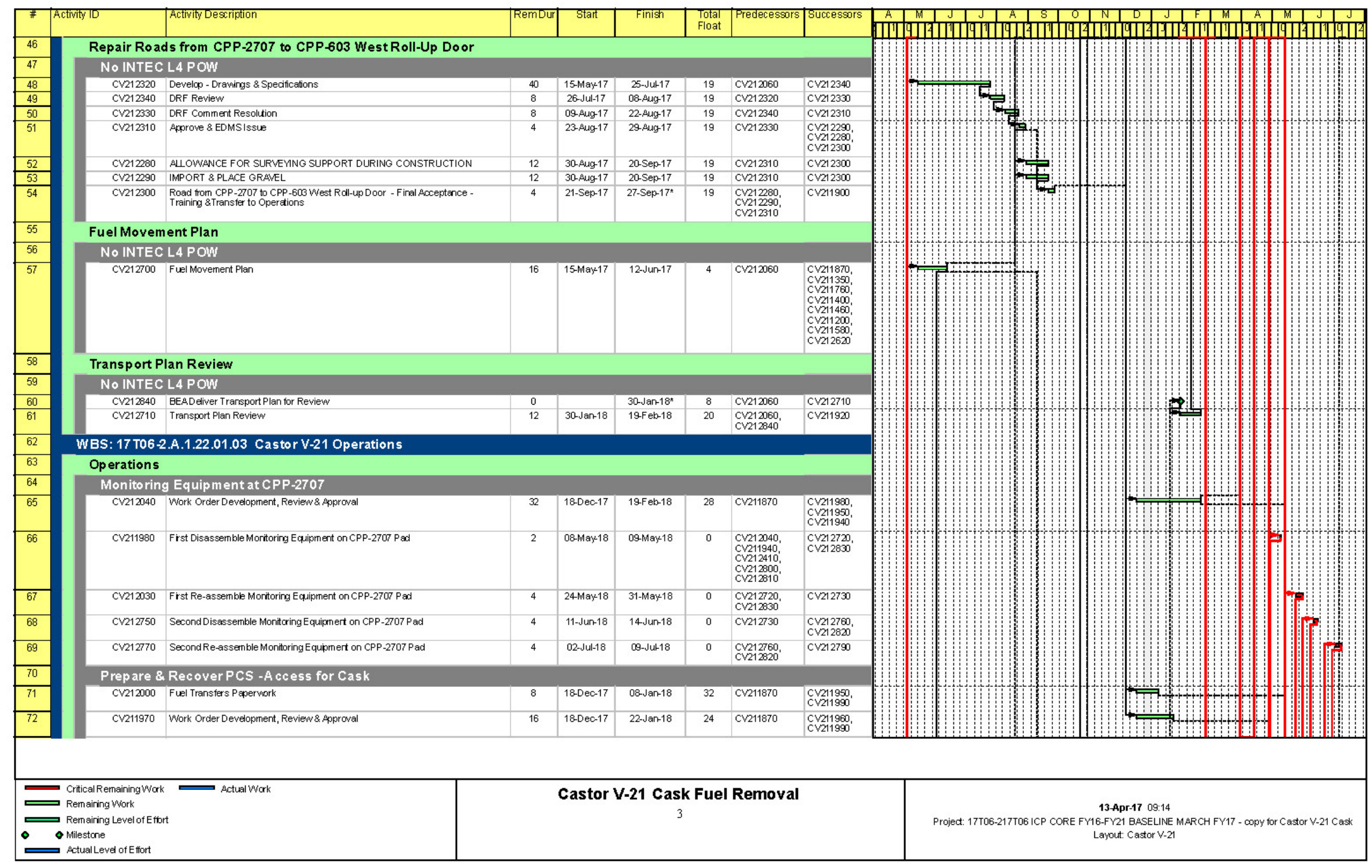




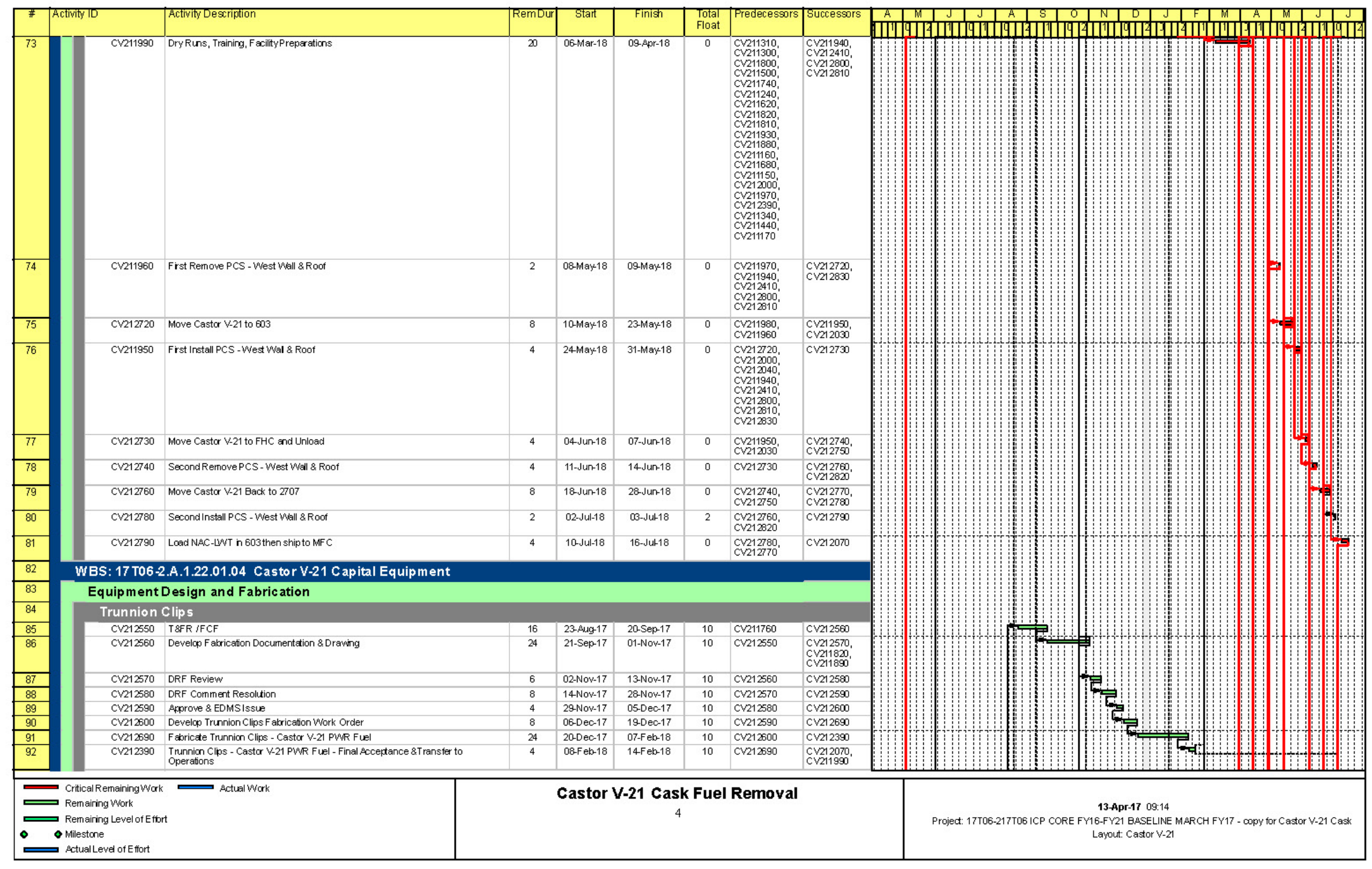




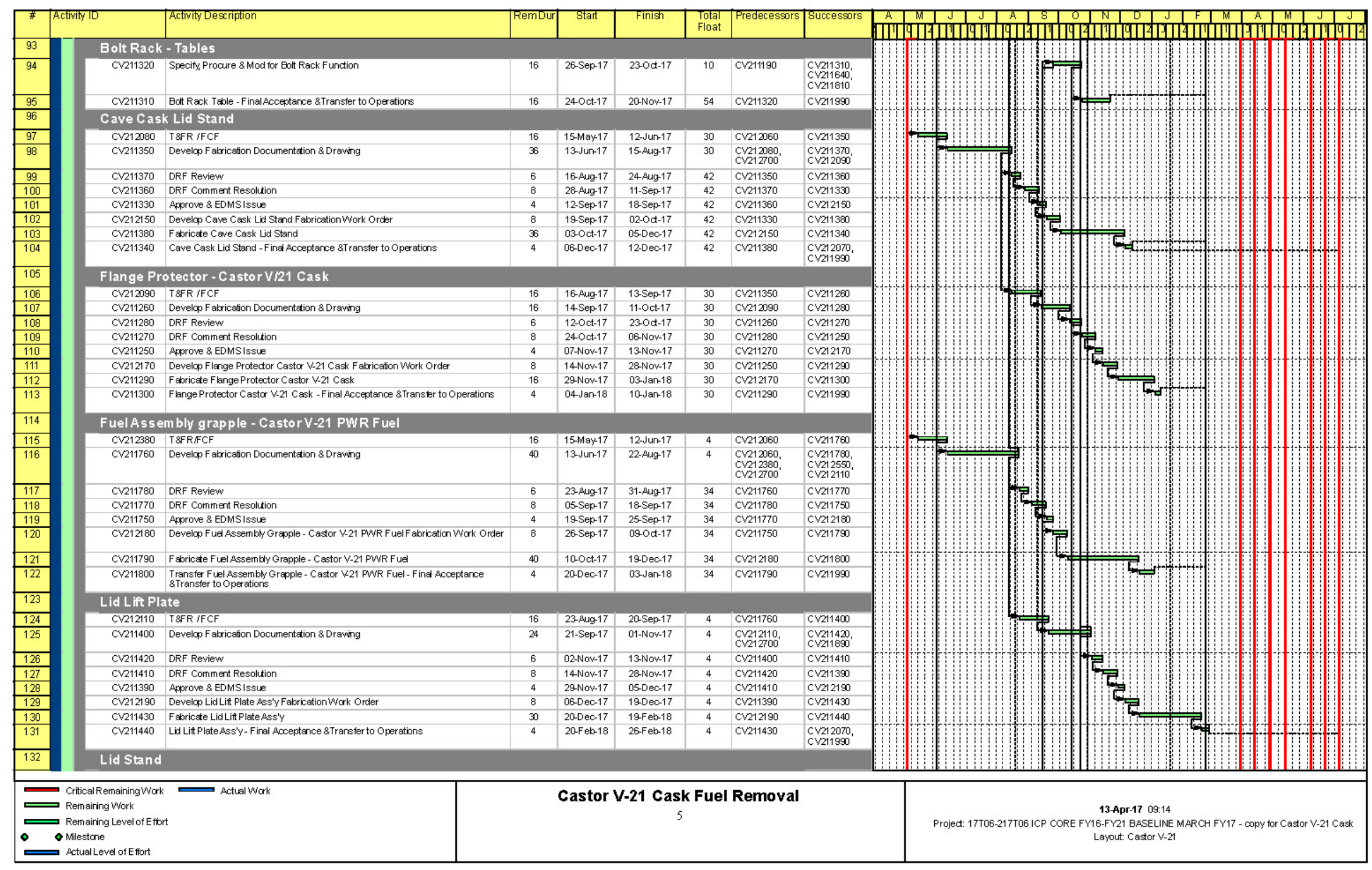




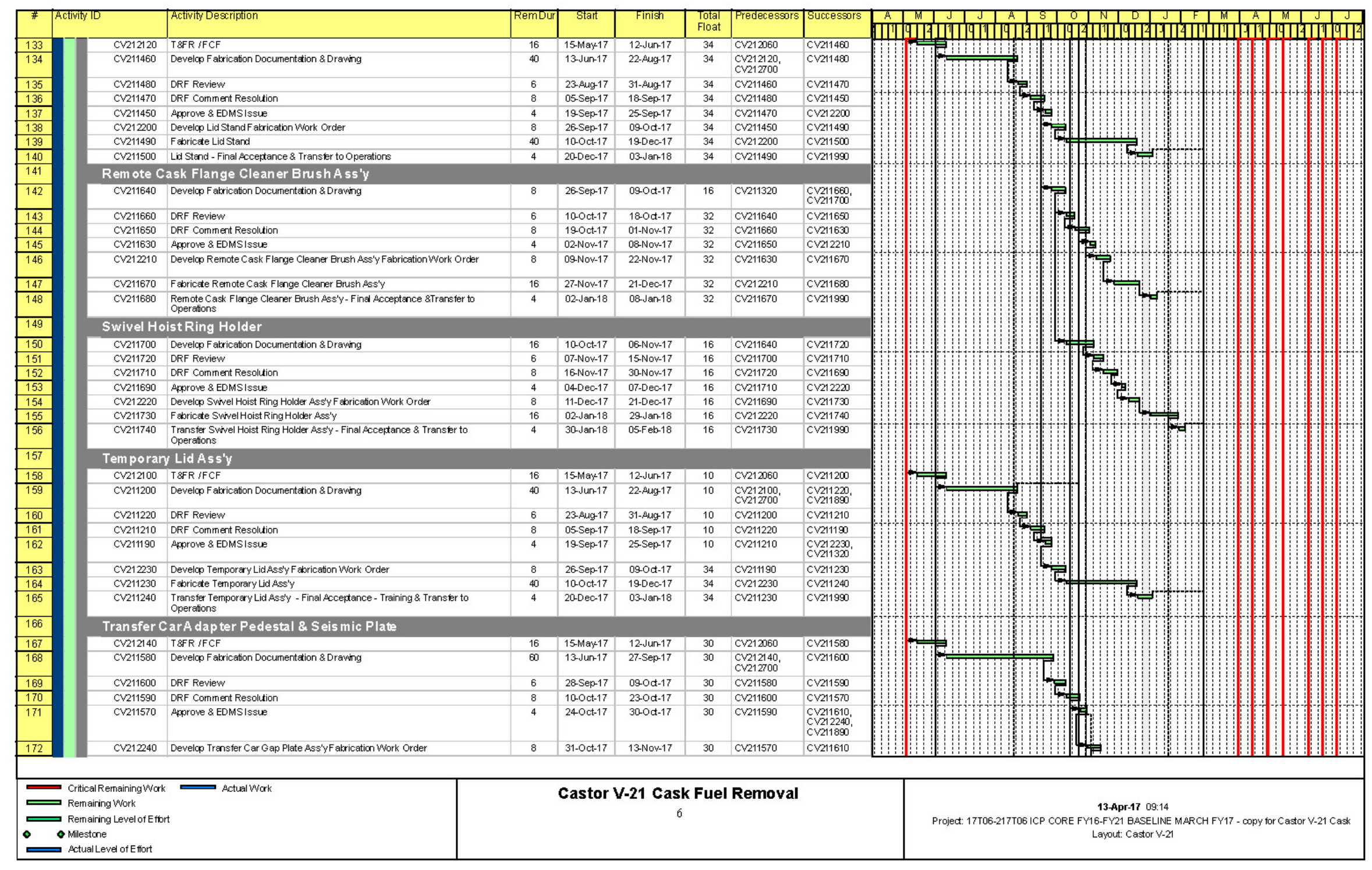




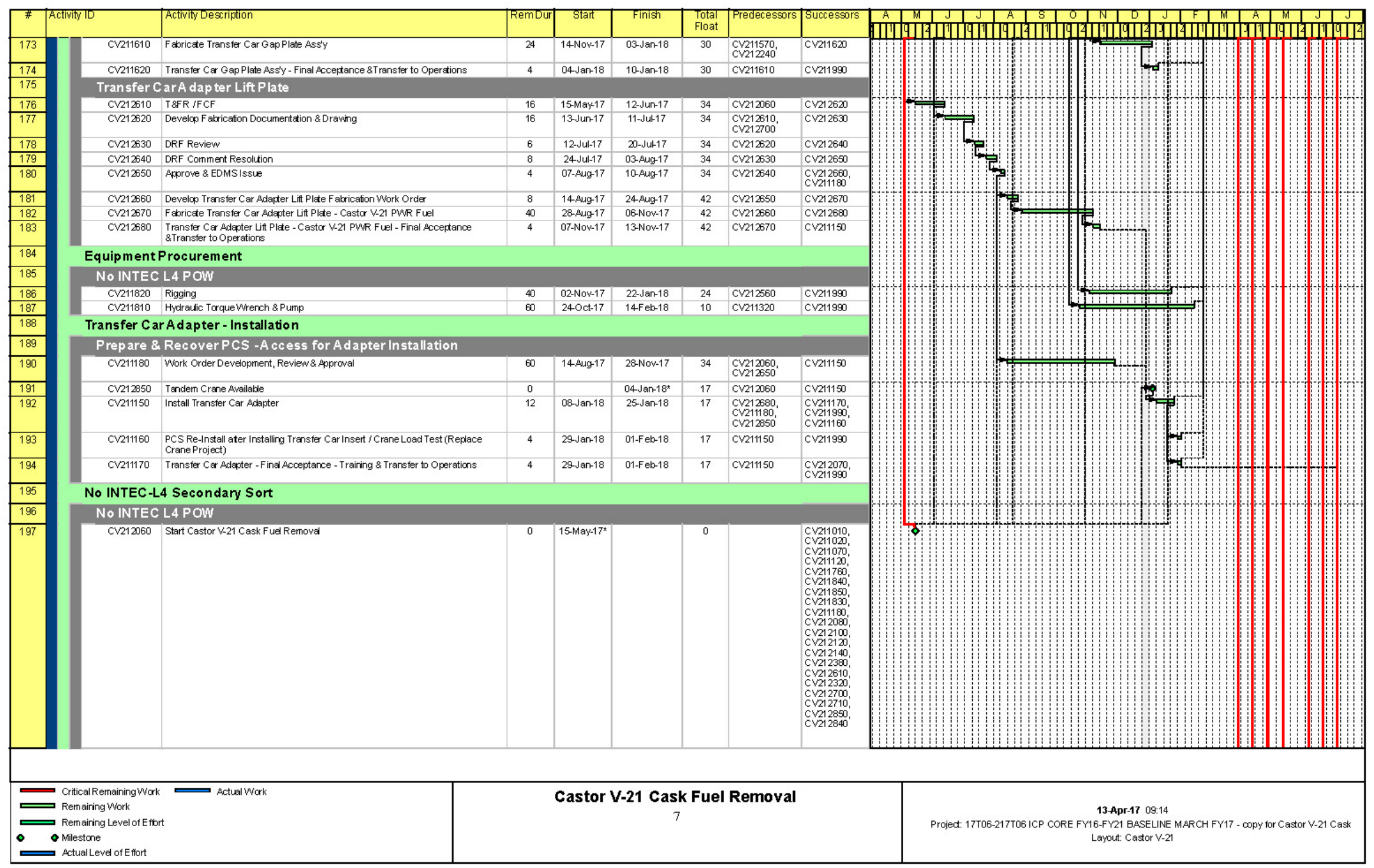




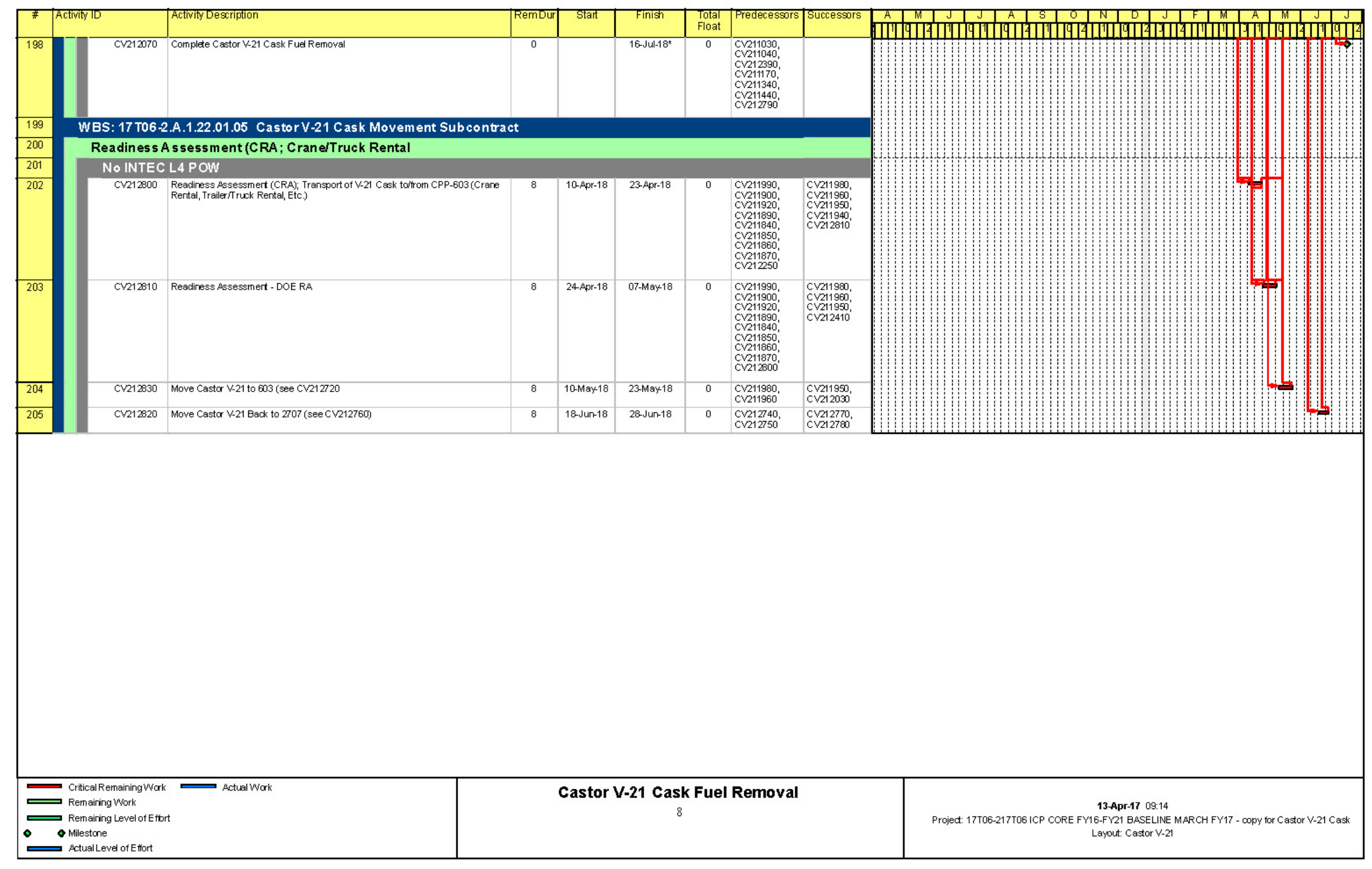

